\title{
Global Carbon Budget 2017
}

Corinne Le Quéré1, Robbie M. Andrew ${ }^{2}$, Pierre Friedlingstein ${ }^{3}$, Stephen Sitch $^{4}$, Julia Pongratz ${ }^{5}$, Andrew C. Manning ${ }^{6}$, Jan Ivar Korsbakken ${ }^{2}$, Glen P. Peters ${ }^{2}$, Josep G. Canadell ${ }^{7}$, Robert B. Jackson ${ }^{8}$, Thomas A. Boden ${ }^{9}$, Pieter P. Tans ${ }^{10}$, Oliver D. Andrews ${ }^{1}$, Vivek K. Arora ${ }^{11}$, Dorothee C. E. Bakker ${ }^{6}$, Leticia Barbero $^{12,13}$, Meike Becker ${ }^{14,15}$, Richard A. Betts ${ }^{16,4}$, Laurent Bopp ${ }^{17}$, Frédéric Chevallier $^{18}$, Louise P. Chini ${ }^{19}$, Philippe Ciais ${ }^{18}$, Catherine E. Cosca ${ }^{20}$, Jessica Cross ${ }^{20}$, Kim Currie ${ }^{21}$,

Thomas Gasser $^{22}$, Ian Harris ${ }^{23}$, Judith Hauck ${ }^{24}$, Vanessa Haverd ${ }^{25}$, Richard A. Houghton ${ }^{26}$,

Christopher W. Hunt ${ }^{27}$, George Hurtt ${ }^{19}$, Tatiana Ilyina ${ }^{5}$, Atul K. Jain ${ }^{28}$, Etsushi Kato ${ }^{29}$, Markus Kautz $^{30}$, Ralph F. Keeling ${ }^{31}$, Kees Klein Goldewijk ${ }^{32,33}$, Arne Körtzinger ${ }^{34}$,

Peter Landschützer ${ }^{5}$, Nathalie Lefèvre ${ }^{35}$, Andrew Lenton ${ }^{36,37}$, Sebastian Lienert ${ }^{38,39}$, Ivan Lima ${ }^{40}$, Danica Lombardozzi ${ }^{41}$, Nicolas Metzl ${ }^{35}$, Frank Millero ${ }^{42}$, Pedro M. S. Monteiro ${ }^{43}$, David R. Munro ${ }^{44}$, Julia E. M. S. Nabel ${ }^{5}$, Shin-ichiro Nakaoka ${ }^{45}$, Yukihiro Nojiri ${ }^{45}$, X. Antonio Padin ${ }^{46}$, Anna Peregon ${ }^{18}$, Benjamin Pfeil $^{14,15}$, Denis Pierrot ${ }^{12,13}$, Benjamin Poulter ${ }^{47,48}$, Gregor Rehder ${ }^{49}$, Janet Reimer ${ }^{50}$, Christian Rödenbeck $^{51}$, Jörg Schwinger ${ }^{52}$, Roland Séférian ${ }^{53}$, Ingunn Skjelvan ${ }^{52}$,

Benjamin D. Stocker ${ }^{54}$, Hanqin Tian ${ }^{55}$, Bronte Tilbrook ${ }^{36,37}$, Francesco N. Tubiello ${ }^{56}$,

Ingrid T. van der Laan-Luijkx ${ }^{57}$, Guido R. van der Werf ${ }^{58}$, Steven van Heuven ${ }^{59}$, Nicolas Viovy ${ }^{18}$, Nicolas Vuichard ${ }^{18}$, Anthony P. Walker ${ }^{60}$, Andrew J. Watson ${ }^{4}$, Andrew J. Wiltshire ${ }^{16}$, Sönke Zaehle ${ }^{51}$, and Dan $\mathbf{Z h u}^{18}$

${ }^{1}$ Tyndall Centre for Climate Change Research, University of East Anglia, Norwich Research Park, Norwich NR4 7TJ, UK

${ }^{2}$ CICERO Center for International Climate Research, 0349 Oslo, Norway

${ }^{3}$ College of Engineering, Mathematics and Physical Sciences, University of Exeter, Exeter EX4 4QF, UK

${ }^{4}$ College of Life and Environmental Sciences, University of Exeter, Exeter EX4 4RJ, UK

${ }^{5}$ Max Planck Institute for Meteorology, Hamburg, Germany

${ }^{6}$ Centre for Ocean and Atmospheric Sciences, School of Environmental Sciences, University of East Anglia, Norwich Research Park, Norwich NR4 7TJ, UK

${ }^{7}$ Global Carbon Project, CSIRO Oceans and Atmosphere, GPO Box 1700, Canberra, ACT 2601, Australia

${ }^{8}$ Department of Earth System Science, Woods Institute for the Environment and Precourt Institute for Energy, Stanford University, Stanford, CA 94305, USA

${ }^{9}$ Climate Change Science Institute, Oak Ridge National Laboratory, Oak Ridge, TN 37831, USA

${ }^{10}$ National Oceanic and Atmospheric Administration, Earth System Research Laboratory

(NOAA/ESRL), Boulder, CO 80305, USA

${ }^{11}$ Canadian Centre for Climate Modelling and Analysis, Climate Research Division, Environment and Climate Change Canada, Victoria, BC, Canada

${ }^{12}$ Cooperative Institute for Marine and Atmospheric Studies, Rosenstiel School for Marine and Atmospheric Science, University of Miami, Miami, FL 33149, USA

${ }^{13}$ National Oceanic and Atmospheric Administration/Atlantic Oceanographic and Meteorological Laboratory (NOAA/AOML), Miami, FL 33149, USA

${ }^{14}$ Geophysical Institute, University of Bergen, 5020 Bergen, Norway

${ }^{15}$ Bjerknes Centre for Climate Research, 5007 Bergen, Norway

${ }^{16}$ Met Office Hadley Centre, FitzRoy Road, Exeter EX1 3PB, UK

${ }^{17}$ Laboratoire de Météorologie Dynamique, Institut Pierre-Simon Laplace, CNRS-ENS-UPMC-X,

Département de Géosciences, École Normale Supérieure, 24 rue Lhomond, 75005 Paris, France

${ }^{18}$ Laboratoire des Sciences du Climat et de l'Environnement, Institut Pierre-Simon Laplace, CEA-CNRS-UVSQ, CE Orme des Merisiers, 91191 Gif-sur-Yvette CEDEX, France 
${ }^{19}$ Department of Geographical Sciences, University of Maryland, College Park, MD 20742, USA

${ }^{20}$ Pacific Marine Environmental Laboratory, National Oceanic and Atmospheric Administration, Seattle, WA 98115, USA

${ }^{21}$ National Institute of Water and Atmospheric Research (NIWA), Dunedin 9054, New Zealand

${ }^{22}$ International Institute for Applied Systems Analysis (IIASA), 2361 Laxenburg, Austria

${ }^{23}$ NCAS-Climate, Climatic Research Unit, School of Environmental Sciences, University of East Anglia, Norwich Research Park, Norwich, NR4 7TJ, UK

${ }^{24}$ Alfred Wegener Institute Helmholtz Centre for Polar and Marine Research, Postfach 120161, 27515 Bremerhaven, Germany

${ }^{25}$ CSIRO Oceans and Atmosphere, GPO Box 1700, Canberra, ACT 2601, Australia

${ }^{26}$ Woods Hole Research Centre (WHRC), Falmouth, MA 02540, USA

${ }^{27}$ Ocean Process Analysis Laboratory, University of New Hampshire, Durham, NH 03824, USA

${ }^{28}$ Department of Atmospheric Sciences, University of Illinois, Urbana, IL 61801, USA

${ }^{29}$ Institute of Applied Energy (IAE), Minato-ku, Tokyo 105-0003, Japan

${ }^{30}$ Karlsruhe Institute of Technology, Institute of Meteorology and Climate Research/Atmospheric Environmental Research, 82467 Garmisch-Partenkirchen, Germany

${ }^{31}$ University of California, San Diego, Scripps Institution of Oceanography, La Jolla, CA 92093-0244, USA

${ }^{32}$ PBL Netherlands Environmental Assessment Agency, Bezuidenhoutseweg 30, P.O. Box 30314, $2500 \mathrm{GH}$, The Hague, the Netherlands

${ }^{33}$ Faculty of Geosciences, Department IMEW, Copernicus Institute of Sustainable Development, Heidelberglaan 2, P.O. Box 80115, 3508 TC, Utrecht, the Netherlands

${ }^{34}$ GEOMAR Helmholtz Centre for Ocean Research Kiel, Düsternbrooker Weg 20, 24105 Kiel, Germany

${ }^{35}$ Sorbonne Universités (UPMC, Univ Paris 06), CNRS, IRD, MNHN, LOCEAN/IPSL Laboratory, 75252 Paris, France

${ }^{36}$ CSIRO Oceans and Atmosphere, P.O. Box 1538, Hobart, TAS, Australia

${ }^{37}$ Antarctic Climate and Ecosystem Cooperative Research Centre, University of Tasmania, Hobart, TAS, Australia

${ }^{38}$ Climate and Environmental Physics, Physics Institute, University of Bern, Bern, Switzerland

${ }^{39}$ Oeschger Centre for Climate Change Research, University of Bern, Bern, Switzerland

${ }^{40}$ Woods Hole Oceanographic Institution (WHOI), Woods Hole, MA 02543, USA

${ }^{41}$ National Center for Atmospheric Research, Climate and Global Dynamics, Terrestrial Sciences Section, Boulder, CO 80305, USA

${ }^{42}$ Department of Ocean Sciences, RSMAS/MAC, University of Miami, 4600 Rickenbacker Causeway, Miami, FL 33149, USA

${ }^{43}$ Ocean Systems and Climate, CSIR-CHPC, Cape Town, 7700, South Africa

${ }^{44}$ Department of Atmospheric and Oceanic Sciences and Institute of Arctic and Alpine Research,

University of Colorado, Campus Box 450, Boulder, CO 80309-0450, USA

${ }^{45}$ Center for Global Environmental Research, National Institute for Environmental Studies (NIES), 16-2 Onogawa, Tsukuba, Ibaraki 305-8506, Japan

${ }^{46}$ Instituto de Investigacións Mariñas (CSIC), Vigo 36208, Spain

${ }^{47}$ NASA Goddard Space Flight Center, Biospheric Science Laboratory, Greenbelt, MD 20771, USA

${ }^{48}$ Department of Ecology, Montana State University, Bozeman, MT 59717, USA

${ }^{49}$ Leibniz Institute for Baltic Sea Research Warnemünde, 18119 Rostock, Germany

${ }^{50}$ School of Marine Science and Policy, University of Delaware, Newark, DE 19716, USA

${ }^{51}$ Max Planck Institute for Biogeochemistry, P.O. Box 600164, Hans-Knöll-Str. 10, 07745 Jena, Germany

${ }^{52}$ Uni Research Climate, Bjerknes Centre for Climate Research, 5007 Bergen, Norway

${ }^{53}$ Centre National de Recherche Météorologique, Unite mixte de recherche 3589 Météo-France/CNRS, 42 Avenue Gaspard Coriolis, 31100 Toulouse, France

${ }^{54}$ CREAF, E08193 Bellaterra (Cerdanyola del Vallès), Catalonia, Spain

${ }^{55}$ School of Forestry and Wildlife Sciences, Auburn University, 602 Ducan Drive, Auburn, AL 36849, USA

${ }^{56}$ Statistics Division, Food and Agriculture Organization of the United Nations, Via Terme di Caracalla, Rome 00153, Italy

${ }^{57}$ Department of Meteorology and Air Quality, Wageningen University \& Research, P.O. Box 47, 6700AA Wageningen, the Netherlands

${ }^{58}$ Faculty of Science, Vrije Universiteit Amsterdam, Amsterdam, the Netherlands 
${ }^{59}$ Energy and Sustainability Research Institute Groningen (ESRIG), University of Groningen, Groningen, the Netherlands

${ }^{60}$ Environmental Sciences Division \& Climate Change Science Institute, Oak Ridge National Laboratory, Oak Ridge, TN, USA

Correspondence: Corinne Le Quéré (c.lequere@uea.ac.uk)

Received: 1 November 2017 - Discussion started: 13 November 2017

Revised: 16 February 2018 - Accepted: 19 February 2018 - Published: 12 March 2018

\begin{abstract}
Accurate assessment of anthropogenic carbon dioxide $\left(\mathrm{CO}_{2}\right)$ emissions and their redistribution among the atmosphere, ocean, and terrestrial biosphere - the "global carbon budget" - is important to better understand the global carbon cycle, support the development of climate policies, and project future climate change. Here we describe data sets and methodology to quantify the five major components of the global carbon budget and their uncertainties. $\mathrm{CO}_{2}$ emissions from fossil fuels and industry $\left(E_{\mathrm{FF}}\right)$ are based on energy statistics and cement production data, respectively, while emissions from land-use change $\left(E_{\mathrm{LUC}}\right)$, mainly deforestation, are based on land-cover change data and bookkeeping models. The global atmospheric $\mathrm{CO}_{2}$ concentration is measured directly and its rate of growth $\left(G_{\mathrm{ATM}}\right)$ is computed from the annual changes in concentration. The ocean $\mathrm{CO}_{2}$ sink $\left(S_{\text {OCEAN }}\right)$ and terrestrial $\mathrm{CO}_{2}$ sink $\left(S_{\text {LAND }}\right)$ are estimated with global process models constrained by observations. The resulting carbon budget imbalance $\left(B_{\mathrm{IM}}\right)$, the difference between the estimated total emissions and the estimated changes in the atmosphere, ocean, and terrestrial biosphere, is a measure of imperfect data and understanding of the contemporary carbon cycle. All uncertainties are reported as $\pm 1 \sigma$. For the last decade available (2007-2016), $E_{\mathrm{FF}}$ was $9.4 \pm 0.5 \mathrm{GtC} \mathrm{yr}^{-1}, E_{\mathrm{LUC}} 1.3 \pm 0.7 \mathrm{GtC} \mathrm{yr}^{-1}, G_{\mathrm{ATM}} 4.7 \pm 0.1 \mathrm{GtC} \mathrm{yr}^{-1}$, $S_{\text {OCEAN }} 2.4 \pm 0.5 \mathrm{GtC} \mathrm{yr}^{-1}$, and $S_{\text {LAND }} 3.0 \pm 0.8 \mathrm{GtC} \mathrm{yr}^{-1}$, with a budget imbalance $B_{\mathrm{IM}}$ of $0.6 \mathrm{GtC} \mathrm{yr}^{-1}$ indicating overestimated emissions and/or underestimated sinks. For year 2016 alone, the growth in $E_{\mathrm{FF}}$ was ap-

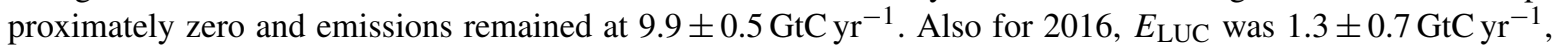
$G_{\text {ATM }}$ was $6.1 \pm 0.2 \mathrm{GtC} \mathrm{yr}^{-1}, S_{\text {OCEAN }}$ was $2.6 \pm 0.5 \mathrm{GtC} \mathrm{yr}^{-1}$, and $S_{\text {LAND }}$ was $2.7 \pm 1.0 \mathrm{GtC} \mathrm{yr}^{-1}$, with a small $B_{\mathrm{IM}}$ of $-0.3 \mathrm{GtC}$. $G_{\mathrm{ATM}}$ continued to be higher in 2016 compared to the past decade (2007-2016), reflecting in part the high fossil emissions and the small $S_{\text {LAND }}$ consistent with El Niño conditions. The global atmospheric $\mathrm{CO}_{2}$ concentration reached $402.8 \pm 0.1 \mathrm{ppm}$ averaged over 2016. For 2017, preliminary data for the first 6-9 months indicate a renewed growth in $E_{\mathrm{FF}}$ of $+2.0 \%$ (range of 0.8 to $3.0 \%$ ) based on national emissions projections for China, USA, and India, and projections of gross domestic product (GDP) corrected for recent changes in the carbon intensity of the economy for the rest of the world. This living data update documents changes in the methods and data sets used in this new global carbon budget compared with previous publications of this data set (Le Quéré et al., 2016, 2015b, a, 2014, 2013). All results presented here can be downloaded from https://doi.org/10.18160/GCP-2017 (GCP, 2017).
\end{abstract}

\section{Introduction}

The concentration of carbon dioxide $\left(\mathrm{CO}_{2}\right)$ in the atmosphere has increased from approximately 277 parts per million (ppm) in 1750 (Joos and Spahni, 2008), the beginning of the industrial era, to $402.8 \pm 0.1 \mathrm{ppm}$ in 2016 (Dlugokencky and Tans, 2018; Fig. 1). The atmospheric $\mathrm{CO}_{2}$ increase above pre-industrial levels was, initially, primarily caused by the release of carbon to the atmosphere from deforestation and other land-use change activities (Ciais et al., 2013). While emissions from fossil fuels started before the industrial era, they only became the dominant source of anthropogenic emissions to the atmosphere from around 1920 and their relative share has continued to increase until present. Anthropogenic emissions occur on top of an active natural carbon cycle that circulates carbon between the reservoirs of the atmosphere, ocean, and terrestrial biosphere on timescales from sub-daily to millennia, while exchanges with geologic reservoirs occur on longer timescales (Archer et al., 2009).

The global carbon budget presented here refers to the mean, variations, and trends in the perturbation of $\mathrm{CO}_{2}$ in the environment, referenced to the beginning of the industrial era. It quantifies the input of $\mathrm{CO}_{2}$ to the atmosphere by emissions from human activities, the growth rate of atmospheric $\mathrm{CO}_{2}$ concentration, and the resulting changes in the storage of carbon in the land and ocean reservoirs in response to increasing atmospheric $\mathrm{CO}_{2}$ levels, climate change and variability, and other anthropogenic and natural changes (Fig. 2). An understanding of this perturbation budget over time and the underlying variability and trends of the natural carbon cycle are necessary to understand the response of natural sinks to changes in climate, $\mathrm{CO}_{2}$ and land-use change 


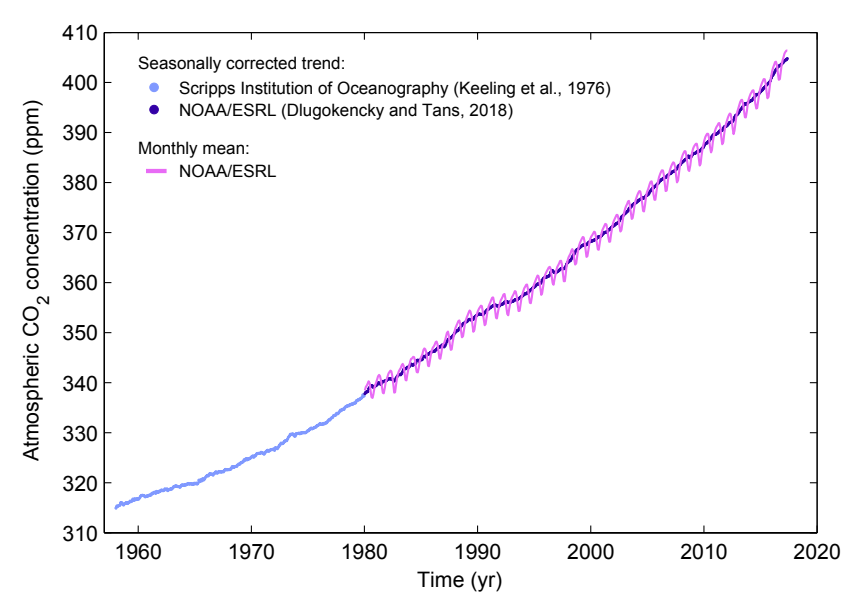

Figure 1. Surface average atmospheric $\mathrm{CO}_{2}$ concentration (ppm). The 1980-2017 monthly data are from NOAA/ESRL (Dlugokencky and Tans, 2018) and are based on an average of direct atmospheric $\mathrm{CO}_{2}$ measurements from multiple stations in the marine boundary layer (Masarie and Tans, 1995). The 1958-1979 monthly data are from the Scripps Institution of Oceanography, based on an average of direct atmospheric $\mathrm{CO}_{2}$ measurements from the Mauna Loa and South Pole stations (Keeling et al., 1976). To take into account the difference of mean $\mathrm{CO}_{2}$ and seasonality between the NOAA/ESRL and the Scripps station networks used here, the Scripps surface average (from two stations) was deseasonalised and harmonised to match the NOAA/ESRL surface average (from multiple stations) by adding the mean difference of $0.542 \mathrm{ppm}$, calculated here from overlapping data during 1980-2012.

drivers, and the permissible emissions for a given climate stabilisation target.

The components of the $\mathrm{CO}_{2}$ budget that are reported annually in this paper include separate estimates for the $\mathrm{CO}_{2}$ emissions from (1) fossil fuel combustion and oxidation and

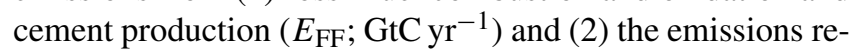
sulting from deliberate human activities on land, including

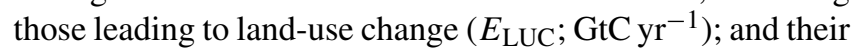
partitioning among (3) the growth rate of atmospheric $\mathrm{CO}_{2}$ concentration $\left(G_{\mathrm{ATM}} ; \mathrm{GtC} \mathrm{yr}^{-1}\right)$; and the uptake of $\mathrm{CO}_{2}$ (the "CO ${ }_{2}$ sinks") in (4) the ocean ( $\left.S_{\text {OCEAN }} ; \mathrm{GtC} \mathrm{yr}^{-1}\right)$ and (5) on

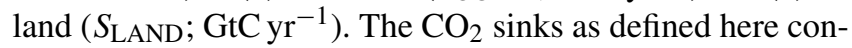
ceptually include the response of the land (including inland waters and estuaries) and ocean (including coasts and territorial sea) to elevated $\mathrm{CO}_{2}$ and changes in climate, rivers, and other environmental conditions, although in practice not all processes are accounted for (see Sect. 2.7). The global emissions and their partitioning among the atmosphere, ocean, and land are in reality in balance; however, due to imperfect spatial and/or temporal data coverage, errors in each estimate, and smaller terms not included in our budget estimate (discussed in Sect. 2.7), their sum does not necessarily add up to zero. We introduce here a budget imbalance $\left(B_{\mathrm{IM}}\right)$, which is a measure of the mismatch between the estimated emissions and the estimated changes in the atmosphere, land, and ocean. This is an important change in calculation of the global carbon budget, which opens up new insights in the assessment of each term individually (Schimel et al., 2015). With this change, the full global carbon budget now reads as follows:

$E_{\mathrm{FF}}+E_{\mathrm{LUC}}=G_{\mathrm{ATM}}+S_{\mathrm{OCEAN}}+S_{\mathrm{LAND}}+B_{\mathrm{IM}}$.

$G_{\text {ATM }}$ is usually reported in $\mathrm{ppm} \mathrm{yr}^{-1}$, which we convert to units of carbon mass per year, $\mathrm{GtC} \mathrm{yr}^{-1}$, using $1 \mathrm{ppm}=2.12 \mathrm{GtC}$ (Table 1 ). We also include a quantification of $E_{\mathrm{FF}}$ by country, computed with both territorial and consumption-based accounting (see Sect. 2), and discuss missing terms from sources other than the combustion of fossil fuels (see Sect. 2.7).

The $\mathrm{CO}_{2}$ budget has been assessed by the Intergovernmental Panel on Climate Change (IPCC) in all assessment reports (Ciais et al., 2013; Denman et al., 2007; Prentice et al., 2001; Schimel et al., 1995; Watson et al., 1990) and by others (e.g. Ballantyne et al., 2012). The IPCC methodology has been adapted and used by the Global Carbon Project (GCP, http://www.globalcarbonproject.org), which has coordinated a cooperative community effort for the annual publication of global carbon budgets up to year 2005 (Raupach et al., 2007; including fossil emissions only), year 2006 (Canadell et al., 2007), year 2007 (published online; GCP, 2007), year 2008 (Le Quéré et al., 2009), year 2009 (Friedlingstein et al., 2010), year 2010 (Peters et al., 2012b), year 2012 (Le Quéré et al., 2013; Peters et al., 2013), year 2013 (Le Quéré et al., 2014), year 2014 (Friedlingstein et al., 2014; Le Quéré et al., 2015b), year 2015 (Jackson et al., 2016; Le Quéré et al., 2015a), and most recently year 2016 (Le Quéré et al., 2016). Each of these papers updated previous estimates with the latest available information for the entire time series.

We adopt a range of \pm 1 standard deviation $(\sigma)$ to report the uncertainties in our estimates, representing a likelihood of $68 \%$ that the true value will be within the provided range if the errors have a Gaussian distribution. This choice reflects the difficulty of characterising the uncertainty in the $\mathrm{CO}_{2}$ fluxes between the atmosphere and the ocean and land reservoirs individually, particularly on an annual basis, as well as the difficulty of updating the $\mathrm{CO}_{2}$ emissions from land-use change. A likelihood of $68 \%$ provides an indication of our current capability to quantify each term and its uncertainty given the available information. For comparison, the Fifth Assessment Report of the IPCC (AR5) generally reported a likelihood of $90 \%$ for large data sets whose uncertainty is well characterised, or for long time intervals less affected by year-to-year variability. Our $68 \%$ uncertainty value is near the $66 \%$ which the IPCC characterises as "likely" for values falling into the $\pm 1 \sigma$ interval. The uncertainties reported here combine statistical analysis of the underlying data and expert judgement of the likelihood of results lying outside this range. The limitations of current information are discussed in the paper and have been examined in detail elsewhere (Ballantyne et al., 2015; Zscheischler et al., 2017). We also use a 


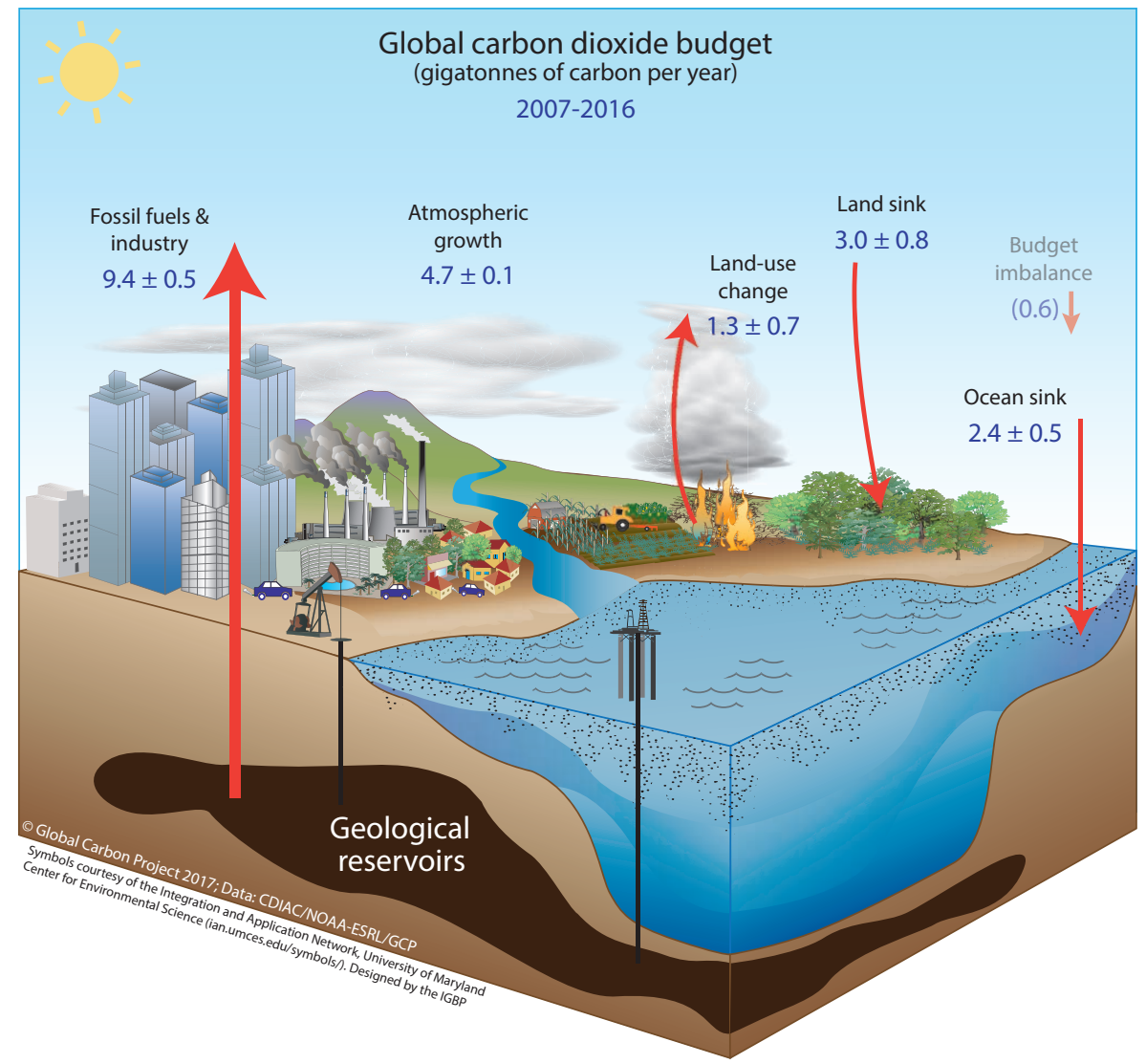

Figure 2. Schematic representation of the overall perturbation of the global carbon cycle caused by anthropogenic activities, averaged globally for the decade 2007-2016. The values represent emission from fossil fuels and industry ( $\left.E_{\mathrm{FF}}\right)$, emissions from deforestation and other land-use change $\left(E_{\mathrm{LUC}}\right)$, the growth rate in atmospheric $\mathrm{CO}_{2}$ concentration $\left(G_{\mathrm{ATM}}\right)$, and the uptake of carbon by the sinks in the ocean $\left(S_{\text {OCEAN }}\right)$ and land $\left(S_{\text {LAND }}\right)$ reservoirs. The budget imbalance $\left(B_{\mathrm{IM}}\right)$ is also shown. All fluxes are in units of $\mathrm{GtC}^{-1}$, with uncertainties reported as $\pm 1 \sigma$ (68\% confidence that the real value lies within the given interval) as described in the text. This figure is an update of one prepared by the International Geosphere-Biosphere Programme for the GCP, using diagrams created with symbols from the Integration and Application Network, University of Maryland Center for Environmental Science (http://ian.umces.edu/symbols/), first presented in Le Quéré (2009).

Table 1. Factors used to convert carbon in various units (by convention, Unit $1=$ Unit 2 conversion).

\begin{tabular}{llrl}
\hline Unit 1 & Unit 2 & Conversion & Source \\
\hline GtC (gigatonnes of carbon) & ppm (parts per million) & $2.12^{\mathrm{b}}$ & Ballantyne et al. (2012) \\
$\mathrm{GtC}$ (gigatonnes of carbon) & $\mathrm{PgC}$ (petagrams of carbon) & 1 & SI unit conversion \\
$\mathrm{GtCO}_{2}$ (gigatonnes of carbon dioxide) & $\mathrm{GtC}$ (gigatonnes of carbon) & 3.664 & $44.01 / 12.011$ in mass equivalent \\
$\mathrm{GtC}$ (gigatonnes of carbon) & $\mathrm{MtC}$ (megatonnes of carbon) & 1000 & SI unit conversion \\
\hline
\end{tabular}

a Measurements of atmospheric $\mathrm{CO}_{2}$ concentration have units of dry-air mole fraction. "ppm" is an abbreviation for micromole per mol of dry air.

$\mathrm{b}$ The use of a factor of 2.12 assumes that all the atmosphere is well mixed within 1 year. In reality, only the troposphere is well mixed and the growth rate of $\mathrm{CO}_{2}$ concentration in the less well-mixed stratosphere is not measured by sites from the NOAA network. Using a factor of 2.12 makes the approximation that the growth rate of $\mathrm{CO}_{2}$ concentration in the stratosphere equals that of the troposphere on a yearly basis.

qualitative assessment of confidence level to characterise the annual estimates from each term based on the type, amount, quality, and consistency of the evidence as defined by the IPCC (Stocker et al., 2013).

All quantities are presented in units of gigatonnes of carbon $\left(\mathrm{GtC}, 10^{15} \mathrm{gC}\right)$, which is the same as petagrams of car- bon (PgC; Table 1). Units of gigatonnes of $\mathrm{CO}_{2}$ (or billion tonnes of $\mathrm{CO}_{2}$ ) used in policy are equal to 3.664 multiplied by the value in units of $\mathrm{GtC}$.

This paper provides a detailed description of the data sets and methodology used to compute the global carbon budget estimates for the period pre-industrial (1750) to 2016 
Table 2. How to cite the individual components of the global carbon budget presented here.

\begin{tabular}{|c|c|}
\hline Component & Primary reference \\
\hline $\begin{array}{l}\text { Global emissions from fossil fuels and industry } \\
\left(E_{\mathrm{FF}}\right) \text {, total and by fuel type }\end{array}$ & Boden et al. (2017) \\
\hline $\begin{array}{l}\text { National territorial emissions from fossil fuels } \\
\text { and industry }\left(E_{\mathrm{FF}}\right)\end{array}$ & $\begin{array}{l}\text { CDIAC source: Boden et al. (2017), } \\
\text { UNFCCC (2017) }\end{array}$ \\
\hline $\begin{array}{l}\text { National consumption-based emissions from } \\
\text { fossil fuels and industry }\left(E_{\mathrm{FF}}\right) \text { by country (con- } \\
\text { sumption) }\end{array}$ & $\begin{array}{l}\text { Peters et al. (2011b) updated as described in this } \\
\text { paper }\end{array}$ \\
\hline Land-use change emissions ( $\left.E_{\mathrm{LUC}}\right)$ & $\begin{array}{l}\text { Average from Houghton and Nassikas (2017) } \\
\text { and Hansis et al. (2015), both updated as de- } \\
\text { scribed in this paper }\end{array}$ \\
\hline $\begin{array}{l}\text { Growth rate in atmospheric } \mathrm{CO}_{2} \text { concentration } \\
\left(G_{\mathrm{ATM}}\right)\end{array}$ & Dlugokencky and Tans (2018) \\
\hline $\begin{array}{l}\text { Ocean and land } \mathrm{CO}_{2} \text { sinks ( } S_{\text {OCEAN }} \text { and } \\
\left.S_{\text {LAND }}\right)\end{array}$ & $\begin{array}{l}\text { This paper for } S_{\text {OCEAN }} \text { and } S_{\text {LAND }} \text { and refer- } \\
\text { ences in Table } 4 \text { for individual models }\end{array}$ \\
\hline
\end{tabular}

and in more detail for the period 1959 to 2016 . It also provides decadal averages starting in 1960 including the last decade (2007-2016), results for the year 2016, and a projection for year 2017. Finally it provides cumulative emissions from fossil fuels and land-use change since year 1750 , the pre-industrial period, and since year 1870, the reference year for the cumulative carbon estimate used by the IPCC (AR5) based on the availability of global temperature data (Stocker et al., 2013). This paper is updated every year using the format of "living data" to keep a record of budget versions and the changes in new data, revision of data, and changes in methodology that lead to changes in estimates of the carbon budget. Additional materials associated with the release of each new version will be posted at the Global Carbon Project website (http://www.globalcarbonproject.org/carbonbudget), with fossil fuel emissions also available through the Global Carbon Atlas (http://www.globalcarbonatlas.org). With this approach, we aim to provide the highest transparency and traceability in the reporting of $\mathrm{CO}_{2}$, the key driver of climate change.

\section{Methods}

Multiple organisations and research groups around the world generated the original measurements and data used to complete the global carbon budget. The effort presented here is thus mainly one of synthesis, where results from individual groups are collated, analysed, and evaluated for consistency. We facilitate access to original data with the understanding that primary data sets will be referenced in future work (see Table 2 for how to cite the data sets). Descriptions of the measurements, models, and methodologies follow below and in depth descriptions of each component are described elsewhere.

This is the 12th version of the global carbon budget and the sixth revised version in the format of a living data update. It builds on the latest published global carbon budget of Le Quéré et al. (2016). The main changes are (1) the inclusion of data to year 2016 (inclusive) and a projection for the global carbon budget for year 2017; (2) the use of two bookkeeping models to assess $E_{\text {LUC }}$ (instead of one); (3) the use of dynamic global vegetation models (DGVMs) to assess $S_{\text {LAND; }}$ (4) the direct use of global ocean biogeochemistry models (GOBMs) to assess $S_{\text {OCEAN }}$ with no normalisation to observations; (5) the introduction of the budget imbalance $B_{\mathrm{IM}}$ as the difference between the estimated emissions and sinks, thus removing the assumption in previous global carbon budgets that the main uncertainties are primarily on the land sink $\left(S_{\text {LAND }}\right)$ and recognising uncertainties in the estimate of $S_{\text {OCEAN, particularly on decadal timescales; }(6) \text { the }}$ addition of a table presenting the major known sources of uncertainties; and (7) the expansion of the model descriptions. The main methodological differences between annual carbon budgets are summarised in Table 3 .

The use of DGVMs and GOBMs to assess $S_{\text {LAND }}$ and

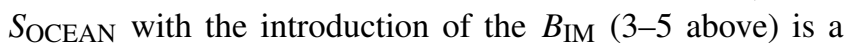
substantial difference from previous global carbon budget publications. This change was introduced after a community discussion held at the 10th International $\mathrm{CO}_{2}$ Conference in 2017, in recognition of two arguments brought forward by the community. First, recent evidence based on observed oceanic constraints suggests that the ocean models used in our global carbon budget may be underestimating the decadal and semi-decadal variability in the ocean sink (Landschützer et al., 2015; DeVries et al., 2017). Second, the 


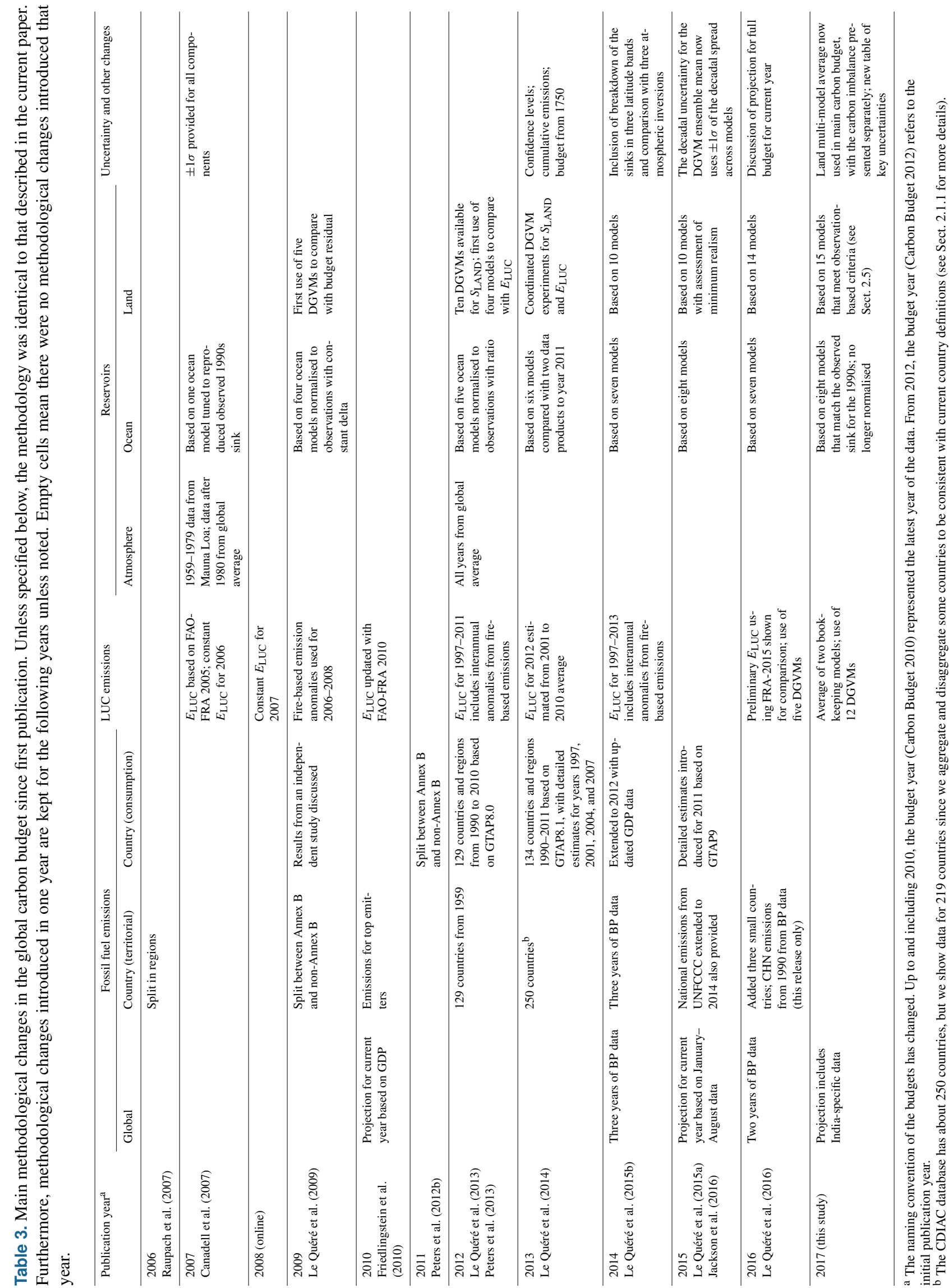


growing need to verify reported emissions with Earth system observations requires that we progress rapidly towards the resolution of remaining inconsistencies in the global carbon budget (Peters et al., 2017). Furthermore, reviewers of Le Quéré et al. (2016) requested that this new edition of the global carbon budget focuses on what we do not know, rather than on what we know. We introduce this change in anticipation that it will trigger new ideas in the way we think about the global carbon budget; produce new, more stringent constraints on each of its components; and result in more evident and transparent attribution of uncertainties.

\section{1 $\mathrm{CO}_{2}$ emissions from fossil fuels and industry $\left(E_{\mathrm{FF}}\right)$}

\subsubsection{Emissions estimates}

The estimates of global and national $\mathrm{CO}_{2}$ emissions from fossil fuels, including gas flaring and cement production $\left(E_{\mathrm{FF}}\right)$, rely primarily on energy consumption data, specifically data on hydrocarbon fuels, collated and archived by several organisations (Andres et al., 2012). We use four main data sets for historical emissions (1751-2016):

1. Global and national emission estimates from CDIAC for the time period 1751-2014 (Boden et al., 2017), as it is the only data set that extends back to 1751 by country.

2. Official UNFCCC national inventory reports for 1990 2015 for the 42 Annex I countries in the UNFCCC (UNFCCC, 2017), as we assess these to be the most accurate estimates because they are compiled by experts within countries which have access to detailed energy data, and they are periodically reviewed.

3. The BP Statistical Review of World Energy (BP, 2017), to project the emissions forward to 2016 to ensure the most recent estimates possible.

4. The US Geological Survey estimates of cement production (USGS, 2017), to estimate cement emissions.

In the following we provide more details in each data set and additional modifications that are required to make the data set consistent and usable.

CDIAC. The CDIAC estimates have been updated annually to include the most recent year (2014) and to include statistical revisions to recent historical data (UN, 2017). Fuel masses and volumes are converted to fuel energy content using country-level coefficients provided by the UN and then converted to $\mathrm{CO}_{2}$ emissions using conversion factors that take into account the relationship between carbon content and energy (heat) content of the different fuel types (coal, oil, gas, gas flaring) and the combustion efficiency (Marland and Rotty, 1984).

UNFCCC. Estimates from the UNFCCC national inventory reports follow the IPCC guidelines (IPCC, 2006) but have a slightly larger system boundary than CDIAC by including emissions coming from carbonates other than in cement manufacturing. We reallocate the detailed UNFCCC estimates to the CDIAC definitions of coal, oil, gas, cement, and other to allow consistent comparisons over time and between countries.

$B P$. For the most recent period when the UNFCCC (2017) and CDIAC (2015-2016) estimates are not available, we generate preliminary estimates using the BP Statistical Review of World Energy (Andres et al., 2014; Myhre et al., 2009). We apply the BP growth rates by fuel type (coal, oil, gas) to estimate 2016 emissions based on 2015 estimates (UNFCCC) and to estimate 2015 and 2016 based on 2014 estimates (CDIAC). BP's data set explicitly covers about 70 countries ( $96 \%$ of global emissions), and for the remaining countries we use growth rates from the subregion the country belongs to. For the most recent years, flaring is assumed constant from the most recent available year of data (2015 for countries that report to the UNFCCC, 2014 for the remainder).

USGS. Estimates of emissions from cement production are based on USGS (USGS, 2017), applying the emission factors from CDIAC (Marland and Rotty, 1984). The CDIAC cement emissions are known to be high and are likely to be revised downwards next year (Andrew, 2018). Some fraction of the $\mathrm{CaO}$ and $\mathrm{MgO}$ in cement is returned to the carbonate form during cement weathering but this is omitted here $(\mathrm{Xi}$ et al., 2016).

Country mappings. The published CDIAC data set includes 256 countries and regions. This list includes countries that no longer exist, such as the USSR and Yugoslavia. We reduce the list to 220 countries by reallocating emissions to the currently defined territories, using mass-preserving aggregation or disaggregation. Examples of aggregation include merging East and West Germany to the currently defined Germany. Examples of disaggregation include reallocating the emissions from the former USSR to the resulting independent countries. For disaggregation, we use the emission shares when the current territories first appeared, and thus historical estimates of disaggregated countries should be treated with extreme care.

Global total. Our global estimate is based on CDIAC, and this is greater than the sum of emissions from all countries. This is largely attributable to emissions that occur in international territory, in particular the combustion of fuels used in international shipping and aviation (bunker fuels). The emissions from international bunker fuels are calculated based on where the fuels were loaded, but we do not include them in the national emissions estimates. Other differences occur (1) because the sum of imports in all countries is not equal to the sum of exports and (2) because of inconsistent national reporting, differing treatment of oxidation of non-fuel uses of hydrocarbons (e.g. as solvents, lubricants, feedstocks), and (3) changes in fuel stored (Andres et al., 2012). 


\subsubsection{Uncertainty assessment for $E_{\mathrm{FF}}$}

We estimate the uncertainty of the global emissions from fossil fuels and industry at $\pm 5 \%$ (scaled down from the published $\pm 10 \%$ at $\pm 2 \sigma$ to the use of $\pm 1 \sigma$ bounds reported here; Andres et al., 2012). This is consistent with a more detailed recent analysis of uncertainty of $\pm 8.4 \%$ at $\pm 2 \sigma$ (Andres et al., 2014) and at the high-end of the range of $\pm 5-10 \%$ at $\pm 2 \sigma$ reported by Ballantyne et al. (2015). This includes an assessment of uncertainties in the amounts of fuel consumed, the carbon and heat contents of fuels, and the combustion efficiency. While we consider a fixed uncertainty of $\pm 5 \%$ for all years, the uncertainty as a percentage of the emissions is growing with time because of the larger share of global emissions from emerging economies and developing countries (Marland et al., 2009). Generally, emissions from mature economies with good statistical processes have an uncertainty of only a few per cent (Marland, 2008), while developing countries such as China have uncertainties of around $\pm 10 \%$ (for $\pm 1 \sigma$; Gregg et al., 2008). Uncertainties of emissions are likely to be mainly systematic errors related to underlying biases of energy statistics and to the accounting method used by each country.

We assign a medium confidence to the results presented here because they are based on indirect estimates of emissions using energy data (Durant et al., 2011). There is only limited and indirect evidence for emissions, although there is a high agreement among the available estimates within the given uncertainty (Andres et al., 2014, 2012), and emission estimates are consistent with a range of other observations (Ciais et al., 2013), even though their regional and national partitioning is more uncertain (Francey et al., 2013).

\subsubsection{Emissions embodied in goods and services}

CDIAC, UNFCCC, and BP national emission statistics "include greenhouse gas emissions and removals taking place within national territory and offshore areas over which the country has jurisdiction" (Rypdal et al., 2006) and are called territorial emission inventories. Consumption-based emission inventories allocate emissions to products that are consumed within a country and are conceptually calculated as the territorial emissions minus the "embodied" territorial emissions to produce exported products plus the emissions in other countries to produce imported products (consumption $=$ territorial - exports + imports). Consumption-based emission attribution results (e.g. Davis and Caldeira, 2010) provide additional information to territorial-based emissions that can be used to understand emission drivers (Hertwich and Peters, 2009) and quantify emission transfers by the trade of products between countries (Peters et al., 2011b). The consumption-based emissions have the same global total but reflect the trade-driven movement of emissions across the Earth's surface in response to human activities.
We estimate consumption-based emissions from 1990 to 2015 by enumerating the global supply chain using a global model of the economic relationships between economic sectors within and between every country (Andrew and Peters, 2013; Peters et al., 2011a). Our analysis is based on the economic and trade data from the Global Trade and Analysis Project (GTAP; Narayanan et al., 2015), and we make detailed estimates for the years 1997 (GTAP version 5), 2001 (GTAP6), and 2004, 2007, and 2011 (GTAP9.2), covering 57 sectors and 141 countries and regions. The detailed results are then extended into an annual time series from 1990 to the latest year of the gross domestic product (GDP) data (2015 in this budget), using GDP data by expenditure in current exchange rate of US dollars (USD; from the UN National Accounts Main Aggregates Database; UN, 2016) and time series of trade data from GTAP (based on the methodology in Peters et al., 2011b). We estimate the sector-level $\mathrm{CO}_{2}$ emissions using the GTAP data and methodology, include flaring and cement emissions from CDIAC, and then scale the national totals (excluding bunker fuels) to match the emission estimates from the carbon budget. We do not provide a separate uncertainty estimate for the consumptionbased emissions, but based on model comparisons and sensitivity analysis, they are unlikely to be significantly different than for the territorial emission estimates (Peters et al. 2012a).

\subsubsection{Growth rate in emissions}

We report the annual growth rate in emissions for adjacent years (in percent per year) by calculating the difference between the two years and then normalising to the emissions in the first year: $\left(E_{\mathrm{FF}}\left(t_{0+1}\right)-E_{\mathrm{FF}}\left(t_{0}\right)\right) / E_{\mathrm{FF}}\left(t_{0}\right) \times 100 \%$. We apply a leap-year adjustment to ensure valid interpretations of annual growth rates. This affects the growth rate by about $0.3 \%(1 / 365)$ and causes growth rates to go up approximately $0.3 \%$ if the first year is a leap year and down $0.3 \%$ if the second year is a leap year.

The relative growth rate of $E_{\mathrm{FF}}$ over time periods of greater than 1 year can be rewritten using its logarithm equivalent as follows:

$$
\frac{1}{E_{\mathrm{FF}}} \frac{\mathrm{d} E_{\mathrm{FF}}}{\mathrm{d} t}=\frac{\mathrm{d}\left(\ln E_{\mathrm{FF}}\right)}{\mathrm{d} t} .
$$

Here we calculate relative growth rates in emissions for multi-year periods (e.g. a decade) by fitting a linear trend to $\ln \left(E_{\mathrm{FF}}\right)$ in Eq. (2), reported in percent per year.

\subsubsection{Emissions projections}

To gain insight on emission trends for the current year (2017), we provide an assessment of global fossil fuel and industry emissions, $E_{\mathrm{FF}}$, by combining individual assessments of emissions for China, USA, India (the three countries with the largest emissions), and the rest of the world. Although the 
EU in aggregate emits more than India, neither official forecasts nor monthly energy statistics are available for the EU as a whole to make a projection for 2017. In consequence, we use GDP projections to infer the emissions for this region.

Our 2017 estimate for China uses (1) estimates of coal consumption, production, imports, and inventory changes from the China Coal Industry Association (CCIA) and the National Energy Agency of China (NEA) for January through June (CCIA, 2017; NEA, 2017); (2) estimated consumption of natural gas and petroleum for January through June from NEA (CCIA, 2017; NEA, 2017); and (3) production of cement reported for January through August (NBS, 2017). Using these data, we estimate the change in emissions for the corresponding months in 2017 compared to 2016 assuming no change in the energy and carbon content of coal for 2017. We then use a central estimate for the growth rate of the whole year that is adjusted down somewhat relative to the first half of the year to account for a slowing trend in industrial growth observed since July and qualitative statements from the NEA saying that they expect oil and coal consumption to be relatively stable for the second half of the year. The main sources of uncertainty are from inconsistencies between available data sources, incomplete data on inventory changes, the carbon content of coal, and the assumptions for the behaviour for the rest of the year. These are discussed further in Sect. 3.2.1.

For the USA, we use the forecast of the US Energy Information Administration (EIA) for emissions from fossil fuels (EIA, 2017). This is based on an energy forecasting model which is revised monthly and takes into account heatingdegree days, household expenditures by fuel type, energy markets, policies, and other effects. We combine this with our estimate of emissions from cement production using the monthly US cement data from USGS for January-June, assuming changes in cement production over the first part of the year apply throughout the year. While the EIA's forecasts for current full-year emissions have on average been revised downwards, only nine such forecasts are available, so we conservatively use the full range of adjustments following revision and additionally assume symmetrical uncertainty to give $\pm 2.7 \%$ around the central forecast.

For India, we use (1) coal production and sales data from the Ministry of Mines, Coal India Limited (CIL, 2017; Ministry of Mines, 2017) and Singareni Collieries Company Limited (SCCL, 2017), combined with imports data from the Ministry of Commerce and Industry (MCI, 2017) and power station stocks data from the Central Electricity Authority (CEA, 2017); (2) oil production and consumption data from the Ministry of Petroleum and Natural Gas (PPAC, 2017b); (3) natural gas production and import data from the Ministry of Petroleum and Natural Gas (PPAC, 2017a); and (4) cement production data from the Office of the Economic Advisor (OEA, 2017). The main source of uncertainty in the projection of India's emissions is the assumption of persistent growth for the rest of the year.
For the rest of the world, we use the close relationship between the growth in GDP and the growth in emissions (Raupach et al., 2007) to project emissions for the current year. This is based on a simplified Kaya identity, whereby $E_{\mathrm{FF}}\left(\mathrm{GtC} \mathrm{yr}^{-1}\right)$ is decomposed by the product of GDP (USD $\mathrm{yr}^{-1}$ ) and the fossil fuel carbon intensity of the economy $\left(I_{\mathrm{FF}} ; \mathrm{GtC} \mathrm{USD}^{-1}\right)$ as follows:

$E_{\mathrm{FF}}=\mathrm{GDP} \times I_{\mathrm{FF}}$.

Taking a time derivative of Eq. (3) and rearranging gives

$\frac{1}{E_{\mathrm{FF}}} \frac{\mathrm{d} E_{\mathrm{FF}}}{\mathrm{d} t}=\frac{1}{\mathrm{GDP}} \frac{\mathrm{dGDP}}{\mathrm{d} t}+\frac{1}{I_{\mathrm{FF}}} \frac{\mathrm{d} I_{\mathrm{FF}}}{\mathrm{d} t}$,

where the left-hand term is the relative growth rate of $E_{\mathrm{FF}}$ and the right-hand terms are the relative growth rates of GDP and $I_{\mathrm{FF}}$, respectively, which can simply be added linearly to give the overall growth rate.

The growth rates are reported in percent by multiplying each term by 100 . As preliminary estimates of annual change in GDP are made well before the end of a calendar year, making assumptions on the growth rate of $I_{\mathrm{FF}}$ allows us to make projections of the annual change in $\mathrm{CO}_{2}$ emissions well before the end of a calendar year. The $I_{\mathrm{FF}}$ is based on GDP in constant PPP (purchasing power parity) from the IEA up to 2014 (IEA/OECD, 2016) and extended using the IMF growth rates for 2015 and 2016 (IMF, 2017). Interannual variability in $I_{\mathrm{FF}}$ is the largest source of uncertainty in the GDP-based emissions projections. We thus use the standard deviation of the annual $I_{\mathrm{FF}}$ for the period 2006-2016 as a measure of uncertainty, reflecting a $\pm 1 \sigma$ as in the rest of the carbon budget. This is $\pm 1.1 \% \mathrm{yr}^{-1}$ for the rest of the world (global emissions minus China, USA, and India).

The 2017 projection for the world is made of the sum of the projections for China, USA, India, and the rest. The uncertainty is added in quadrature among the three regions. The uncertainty here reflects the best of our expert opinion.

\section{2 $\mathrm{CO}_{2}$ emissions from land use, land-use change, and forestry ( $\left.E_{\mathrm{LUC}}\right)$}

The net $\mathrm{CO}_{2}$ flux from land use, land-use change, and forestry reported here ( $E_{\mathrm{LUC}}$, called land-use change emissions in the following) include $\mathrm{CO}_{2}$ fluxes from deforestation, afforestation, logging and forest degradation (including harvest activity), shifting cultivation (cycle of cutting forest for agriculture, then abandoning), and regrowth of forests following wood harvest or abandonment of agriculture. Only some land management activities are included in our landuse change emissions estimates (Table A1). Some of these activities lead to emissions of $\mathrm{CO}_{2}$ to the atmosphere, while others lead to $\mathrm{CO}_{2}$ sinks. $E_{\mathrm{LUC}}$ is the net sum of all anthropogenic activities considered. Our annual estimate for 1959-2016 is provided as the average of results from two bookkeeping models (Sect. 2.2.1): the estimate published 
by Houghton and Nassikas (2017; hereafter H\&N2017) extended here to 2016 and the average of two simulations done with the BLUE model (bookkeeping of land-use emissions; Hansis et al., 2015). In addition, we use results from DGVMs (see Sect. 2.2.3 and Table A1) to help quantify the uncertainty in $E_{\mathrm{LUC}}$ and to explore the consistency of our understanding. The three methods are described below, and differences are discussed in Sect. 3.2.

\subsubsection{Bookkeeping models}

Land-use change $\mathrm{CO}_{2}$ emissions and uptake fluxes are calculated by two bookkeeping models. Both are based on the original bookkeeping approach of Houghton (2003) that keeps track of the carbon stored in vegetation and soils before and after a land-use change (transitions between various natural vegetation types, croplands, and pastures). Literaturebased response curves describe decay of vegetation and soil carbon, including transfer to product pools of different lifetimes, as well as carbon uptake due to regrowth. Additionally, they represents permanent degradation of forests by lower vegetation and soil carbon stocks for secondary as compared to the primary forests and forest management such as wood harvest.

The bookkeeping models do not include land ecosystems' transient response to changes in climate, atmospheric $\mathrm{CO}_{2}$, and other environmental factors, and the carbon densities are based on contemporary data reflecting stable environmental conditions at that time. Since carbon densities remain fixed over time in bookkeeping models, the additional sink capacity that ecosystems provide in response to $\mathrm{CO}_{2}$ fertilisation and some other environmental changes is not captured by these models (Pongratz et al., 2014; see Sect. 2.7.3).

The H\&N2017 and BLUE models differ in (1) computational units (country-level vs. spatially explicit treatment of land-use change), (2) processes represented (see Table A1), and (3) carbon densities assigned to vegetation and soil of each vegetation type. A notable change in H\&N2017 over the original approach by Houghton (2003) used in earlier budget estimates is that no shifting cultivation or other back and forth transitions at a level below country level are included. Only a decline in forest area in a country as indicated by the Forest Resource Assessment of the FAO that exceeds the expansion of agricultural area as indicated by the FAO is assumed to represent a concurrent expansion and abandonment of cropland. In contrast, the BLUE model includes sub-gridscale transitions at the grid level between all vegetation types as indicated by the harmonised land-use change data (LUH2) data set (Hurtt et al., 2018). Furthermore, H\&N2017 assume conversion of natural grasslands to pasture, while BLUE allocates pasture proportionally on all natural vegetation that exists in a grid cell. This is one reason for generally higher emissions in BLUE. H\&N2017 add carbon emissions from peat burning, based on the Global Fire Emissions Database (GFED4s; van der Werf et al., 2017), and peat drainage, based on estimates by Hooijer et al. (2010), to the output of their bookkeeping model for the countries of Indonesia and Malaysia. Peat burning and emissions from the organic layers of drained peat soils, which are not captured by bookkeeping methods directly, need to be included to represent the substantially larger emissions and interannual variability due to synergies of land-use and climate variability in Southeast Asia, in particular during El-Niño events. Similarly to H\&N2017, peat burning and drainage-related emissions are also added to the BLUE estimate based on GFED4s (van der Werf et al., 2017), adding the peat burning for the GFED region of equatorial Asia and the peat drainage for Southeast Asia from Hooijer et al. (2010).

The two bookkeeping estimates used in this study also differ with respect to the land-use change data used to drive the models. H\&N2017 base their estimates directly on the Forest Resource Assessment of the FAO which provides statistics on forest-cover change and management at intervals of 5 years (FAO, 2015). The data are based on countries' selfreporting, some of which include satellite data in more recent assessments. Changes in land use other than forests are based on annual, national changes in cropland and pasture areas reported by FAO (FAOSTAT, 2015). BLUE uses the harmonised land-use change data LUH2 (Hurtt et al., 2018) which describes land-use change, also based on the FAO data, but downscaled at a quarter-degree spatial resolution, considering sub-grid-scale transitions between primary forest, secondary forest, cropland, pasture, and rangeland. The new LUH2 data provide a new distinction between rangelands and pasture. This is implemented by assuming rangelands are treated either all as pastures or all as natural vegetation. These two assumptions are then averaged to provide the BLUE result that is closest to the expected real value.

The estimate of H\&N2017 was extended here by 1 year (to 2016) by adding the anomaly of total peat emissions (burning and drainage) from GFED4s over the previous decade (2006$2015)$ to the decadal average of the bookkeeping result. A small correction to their 2015 value was also made based on the updated peat burning of GFED4s.

\subsubsection{Dynamic global vegetation models (DGVMs)}

Land-use change $\mathrm{CO}_{2}$ emissions have also been estimated using an ensemble of 12 DGVM simulations. The DGVMs account for deforestation and regrowth, the most important components of $E_{\mathrm{LUC}}$, but they do not represent all processes resulting directly from human activities on land (Table A1). All DGVMs represent processes of vegetation growth and mortality, as well as decomposition of dead organic matter associated with natural cycles, and include the vegetation and soil carbon response to increasing atmospheric $\mathrm{CO}_{2}$ levels and to climate variability and change. Some models explicitly simulate the coupling of carbon and nitrogen cycles and account for atmospheric $\mathrm{N}$ deposition (Table A1). The DGVMs are independent from the other budget terms except 
Table 4. References for the process models, $p \mathrm{CO}_{2}$-based ocean flux products, and atmospheric inversions included in Figs. 6-8. All models and products are updated with new data to end of year 2016.

\begin{tabular}{lll}
\hline Model/data name & Reference & Change from Le Quéré et al. (2016) \\
\hline Bookkeeping models for land-use change emissions & \\
\hline BLUE & Hansis et al. (2015) & Not applicable (not used in previous carbon budgets) \\
\hline H\&N2017 & Houghton and Nassikas (2017) & $\begin{array}{l}\text { Updated from Houghton et al. (2012); key differences in- } \\
\text { clude revised land-use change data to FAO2015, revised } \\
\text { vegetation carbon densities, Indonesian and Malaysian peat } \\
\text { burning and drainage added, and removal of shifting culti- } \\
\text { vation. }\end{array}$ \\
\hline
\end{tabular}

Dynamic global vegetation models

CABLE Haverd et al. (2017) Optimisation of plant investment in rubisco- vs. electron-
transport-limited photosynthesis; temperature-dependent onset of spring recovery in evergreen needle leaves.

CLASS-CTEM Melton and Arora (2016)

A soil colour index is now used to determine soil albedo as opposed to soil texture. Soil albedo still gets modulated by other factors including soil moisture.

\begin{tabular}{lll}
\hline CLM4.5(BGC) & Oleson et al. (2013) & No change. \\
\hline DLEM & Tian et al. (2015) & $\begin{array}{l}\text { Consideration of the expansion of cropland and pasture, } \\
\text { compared with no pasture expansion in previous version. }\end{array}$
\end{tabular}

\begin{tabular}{lll}
\hline ISAM & Jain et al. (2013) & No change. \\
\hline JSBACH & Reick et al. (2013) & Adapted the preprocessing of the LUH data; scaling of crop
\end{tabular}
and pasture states and transitions with the desert fractions in JSBACH in order to maintain as much of the prescribed agricultural areas as possible.

\begin{tabular}{lll}
\hline JULES $^{\mathrm{b}}$ & Clark et al. $(2011)^{\mathrm{c}}$ & No Change. \\
\hline LPJ-GUESS & Smith et al. $(2014)^{\mathrm{d}}$ & LUH2 with land use aggregated to LPJ-GUESS land cover \\
& inputs, shifting cultivation based on LUH2 gross transitions \\
& matrix, and wood harvest based on LUH2 area fractions of \\
& wood harvest; $\alpha_{a}$ reduction by $15 \%$.
\end{tabular}

\begin{tabular}{|c|c|c|}
\hline $\mathrm{LPJ}^{\mathrm{e}}$ & Sitch et al. $(2003)^{\mathrm{f}}$ & No change. \\
\hline LPX-Bern & Keller et al. (2017) & $\begin{array}{l}\text { Updated model parameter values (Keller et al., 2017) due to } \\
\text { assimilation of observational data. }\end{array}$ \\
\hline $\mathrm{OCN}$ & Zaehle and Friend (2010) & $\begin{array}{l}\text { Uses r293, including minor bug fixes; use of the CMIP6 N } \\
\text { deposition data set }\end{array}$ \\
\hline ORCHIDEE & Krinner et al. $(2005)^{\mathrm{h}}$ & $\begin{array}{l}\text { Improved water stress, new soil albedo, improved snow } \\
\text { scheme. }\end{array}$ \\
\hline ORCHIDEE-MICT & Guimberteau et al. (2018) & $\begin{array}{l}\text { New version of ORCHIDEE including fires, permafrost re- } \\
\text { gions coupling between soil thermodynamics and carbon } \\
\text { dynamics, and managed grasslands. }\end{array}$ \\
\hline SDGVM & Woodward et al. $(1995)^{\mathrm{i}}$ & $\begin{array}{l}\text { Uses Kattge et al. (2009) Vcmax leaf } \mathrm{N} \text { relationships } \\
\text { (with Oxisol relationship for evergreen broad leaves). }\end{array}$ \\
\hline VISIT & Kato et al. $(2013)^{\mathrm{j}}$ & $\begin{array}{l}\text { LUH2 is applied for land use, wood harvest, and land-use } \\
\text { change. Sensitivity of soil decomposition parameters from } \\
\text { Lloyd and Taylor (1994) are modified. }\end{array}$ \\
\hline
\end{tabular}


Table 4. Continued.

\begin{tabular}{|c|c|c|}
\hline Model/data name & Reference & Change from Le Quéré et al. (2016) \\
\hline \multicolumn{3}{|c|}{ Global ocean biogeochemistry models } \\
\hline CCSM-BEC & Doney et al. (2009) & Change in atmospheric $\mathrm{CO}_{2}$ concentration ${ }^{\mathrm{k}}$. \\
\hline CSIRO & Law et al. (2017) & $\begin{array}{l}\text { Physical model change from MOM4 to MOM5 and at- } \\
\text { mospheric forcing from JRA- } 55 \text {. }\end{array}$ \\
\hline MITgcm-REcoM2 & Hauck et al. (2016) & $\begin{array}{l}1 \% \text { iron solubility and atmospheric forcing from JRA- } \\
55 .\end{array}$ \\
\hline MPIOM-HAMOCC & Ilyina et al. (2013) & $\begin{array}{l}\text { Cyanobacteria added to HAMOCC (Paulsen et al., } \\
\text { 2017). }\end{array}$ \\
\hline NEMO-PISCES (CNRM) & Séférian et al. (2013) & No change. \\
\hline NEMO-PISCES (IPSL) & Aumont and Bopp (2006) & No change. \\
\hline NEMO-PlankTOM5 & Buitenhuis et al. $(2010)^{\mathrm{m}}$ & No change. \\
\hline NorESM-OC & Schwinger et al. (2016) & No change. \\
\hline \multicolumn{3}{|l|}{$p \mathrm{CO}_{2}$-based flux ocean products } \\
\hline Landschützer & Landschützer et al. (2016) & No change. \\
\hline Jena CarboScope & Rödenbeck et al. (2014) & Updated to version oc_1.5. \\
\hline \multicolumn{3}{|l|}{ Atmospheric inversions } \\
\hline CarbonTracker Europe (CTE) & van der Laan-Luijkx et al. (2017) & Minor changes in the inversion setup. \\
\hline Jena CarboScope & Rödenbeck et al. (2003) & $\begin{array}{l}\text { Prior fluxes, outlier removal, changes in atmospheric } \\
\text { observations station suite. }\end{array}$ \\
\hline CAMS & Chevallier et al. (2005) & $\begin{array}{l}\text { Change from half-hourly observations to daily averages } \\
\text { of well-mixed conditions. }\end{array}$ \\
\hline \multicolumn{3}{|c|}{$\begin{array}{l}\text { See also Goll et al. (2015). } \\
\text { Joint UK Land Environment Simulator. } \\
\text { See also Best et al. (2011). } \\
\text { To account for the differences between the derivation of shortwave radiation (SWRAD) from CRU cloudiness and SWRAD from CRU-NCEP, the photosynthesis } \\
\text { scaling parameter } \alpha_{a} \text { was modified ( }-15 \% \text { ) to yield similar results. } \\
\text { Lund-Potsdam-Jena. } \\
\text { Compared to published version, decreased LPJ wood harvest efficiency so that } 50 \% \text { of biomass was removed off-site compared to } 85 \% \text { used in the } 2012 \text { budget. } \\
\text { Residue management of managed grasslands increased so that } 100 \% \text { of harvested grass enters the litter pool. } \\
\text { See also Zaehle et al. (2011). } \\
\text { Compared to published version, revised parameters values for photosynthetic capacity for boreal forests (following assimilation of FLUXNET data), updated } \\
\text { parameters values for stem allocation, maintenance respiration and biomass export for tropical forests (based on literature), and } \mathrm{CO}_{2} \text { down-regulation process added } \\
\text { to photosynthesis. } \\
\text { See also Woodward and Lomas (2004) and Walker et al. (2017). } \\
\text { See also Ito and Inatomi (2012). } \\
\text { K Previous simulations used atmospheric } \mathrm{CO}_{2} \text { concentration from the IPCC IS92a scenario. This has been rerun using observed atmospheric } \mathrm{CO}_{2} \text { concentration } \\
\text { consistent with the protocol used here. } \\
\text { Last included in Le Quére et al. (2015a). } \\
\text { n' With no nutrient restoring below the mixed layer depth. }\end{array}$} \\
\hline
\end{tabular}

for their use of atmospheric $\mathrm{CO}_{2}$ concentration to calculate the fertilisation effect of $\mathrm{CO}_{2}$ on plant photosynthesis.

The DGVMs used the HYDE land-use change data set (Klein Goldewijk et al., 2017a, b), which provides annual, half-degree, fractional data on cropland and pasture. These data are based on annual FAO statistics of change in agricultural area available to 2012 (FAOSTAT, 2015). For the years 2015 and 2016, the HYDE data were extrapolated by country for pastures and cropland separately based on the trend in agricultural area over the previous 5 years. Some models also use an update of the more comprehensive harmonised land-use data set (Hurtt et al., 2011), that further includes fractional data on primary vegetation and secondary vegetation, as well as all underlying transitions between land-use states (Hurtt et al., 2018). This new data set is of quarterdegree fractional areas of land-use states and all transitions between those states, including a new wood harvest reconstruction, new representation of shifting cultivation, crop rotations, management information including irrigation, and fertiliser application. The land-use states now include five 
different crop types in addition to the pasture-rangeland split discussed before. Wood harvest patterns are constrained with Landsat forest loss data.

DGVMs implement land-use change differently (e.g. an increased cropland fraction in a grid cell can either be at the expense of grassland or shrubs, or forest, the latter resulting in deforestation; land cover fractions of the non-agricultural land differ between models). Similarly, model-specific assumptions are applied to convert deforested biomass or deforested area, and other forest product pools into carbon, and different choices are made regarding the allocation of rangelands as natural vegetation or pastures.

The DGVM model runs were forced by either 6-hourly CRU-NCEP or by monthly CRU temperature, precipitation, and cloud cover fields (transformed into incoming surface radiation) based on observations and provided on a $0.5^{\circ} \times 0.5^{\circ}$ grid and updated to 2016 (Harris et al., 2014; Viovy, 2016). The forcing data include both gridded observations of climate and global atmospheric $\mathrm{CO}_{2}$, which change over time (Dlugokencky and Tans, 2018), and $\mathrm{N}$ deposition (as used in some models; Table A1).

Two sets of simulations were performed with the DGVMs. The first forced initially with historical changes in land cover distribution, climate, atmospheric $\mathrm{CO}_{2}$ concentration, and $\mathrm{N}$ deposition and the second, as further described below, with a time-invariant pre-industrial land cover distribution, allowing the models to estimate, by difference with the first simulation, the dynamic evolution of biomass and soil carbon pools in response to prescribed land-cover change. $E_{\mathrm{LUC}}$ is diagnosed in each model by the difference between these two simulations. We only retain model outputs with positive $E_{\mathrm{LUC}}$ during the 1990 s (Table A1). Using the difference between these two DGVM simulations to diagnose $E_{\mathrm{LUC}}$ means the DGVMs account for the loss of additional sink capacity (around $0.3 \mathrm{GtC} \mathrm{yr}^{-1}$; see Sect. 2.7.3), while the bookkeeping models do not.

\subsubsection{Uncertainty assessment for $E_{\mathrm{LUC}}$}

Differences between the bookkeeping models and DGVM models originate from three main sources: the different methodologies, the land-use and land-cover data set, and the different processes represented (Table A1). We examine the results from the DGVM models and of the bookkeeping method to assess the uncertainty in $E_{\mathrm{LUC}}$.

The $E_{\mathrm{LUC}}$ estimate from the DGVMs' multi-model mean is consistent with the average of the emissions from the bookkeeping models (Table 5). However, there are large differences among individual DGVMs (standard deviation at around $0.5-0.6 \mathrm{GtC} \mathrm{yr}^{-1}$; Table 5), between the two bookkeeping models (average of $0.5 \mathrm{GtC} \mathrm{yr}^{-1}$ ), and between the current estimate of H\&N2017 and its previous model version (Houghton et al., 2012) as used in past global carbon budgets (Le Quéré et al., 2016; average of $0.3 \mathrm{GtC} \mathrm{yr}^{-1}$ ). Given the large spread in new estimates we raise our assessment of uncertainty in $E_{\mathrm{LUC}}$ to $\pm 0.7 \mathrm{GtC} \mathrm{yr}^{-1}$ (from $\pm 0.5 \mathrm{GtC} \mathrm{yr}^{-1}$ ) as a semi-quantitative measure of uncertainty for annual and decadal emissions. This reflects our best value judgment that there is at least a $68 \%$ chance $( \pm 1 \sigma)$ that the true land-use change emission lies within the given range, for the range of processes considered here. Prior to 1959 , the uncertainty in $E_{\mathrm{LUC}}$ was taken from the standard deviation of the DGVMs. We assign low confidence to the annual estimates of $E_{\mathrm{LUC}}$ because of the inconsistencies among estimates and of the difficulties in quantifying some of the processes in DGVMs.

\subsubsection{Emissions projections}

We provide an assessment of $E_{\mathrm{LUC}}$ for 2017 by adding the anomaly of fire emissions in deforestation areas, including those from peat fires, from GFED4s (van der Werf et al., 2017) over the last year available. Emissions are estimated using active fire data (MCD14ML; Giglio et al., 2003), which are available in near-real time, and correlations between those and GFED4s emissions for the 2001-2016 period for the 12 corresponding months. Emissions during JanuaryOctober cover most of the fire season in the Amazon and Southeast Asia, where a large part of the global deforestation takes place.

\subsection{Growth rate in atmospheric $\mathrm{CO}_{2}$ concentration $\left(G_{\text {ATM }}\right)$}

\subsubsection{Global growth rate in atmospheric $\mathrm{CO}_{2}$ concentration}

The rate of growth of the atmospheric $\mathrm{CO}_{2}$ concentration is provided by the US National Oceanic and Atmospheric Administration Earth System Research Laboratory (NOAA/ESRL; Dlugokencky and Tans, 2018), which is updated from Ballantyne et al. (2012). For the 1959-1980 period, the global growth rate is based on measurements of atmospheric $\mathrm{CO}_{2}$ concentration averaged from the Mauna Loa and South Pole stations, as observed by the $\mathrm{CO}_{2}$ Program at Scripps Institution of Oceanography (Keeling et al., 1976). For the 1980-2016 time period, the global growth rate is based on the average of multiple stations selected from the marine boundary layer sites with well-mixed background air (Ballantyne et al., 2012), after fitting each station with a smoothed curve as a function of time and averaging by latitude band (Masarie and Tans, 1995). The annual growth rate is estimated by Dlugokencky and Tans (2018) from atmospheric $\mathrm{CO}_{2}$ concentration by taking the average of the most recent December-January months corrected for the average seasonal cycle and subtracting this same average 1 year ear-

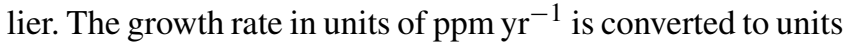
of $\mathrm{GtC} \mathrm{yr}^{-1}$ by multiplying by a factor of $2.12 \mathrm{GtC} \mathrm{ppm}^{-1}$ (Ballantyne et al., 2012). 
Table 5. Comparison of results from the bookkeeping method and budget residuals with results from the DGVMs and inverse estimates for

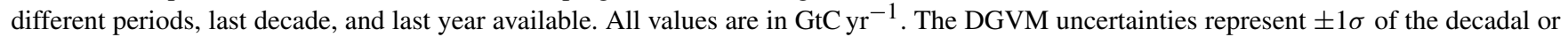
annual (for 2016 only) estimates from the individual DGVMs; for the inverse models all three results are given where available.

\begin{tabular}{|c|c|c|c|c|c|c|c|}
\hline & \multicolumn{7}{|c|}{ Mean $\left(\mathrm{GtC} \mathrm{yr}^{-1}\right)$} \\
\hline & 1960-1969 & 1970-1979 & 1980-1989 & 1990-1999 & 2000-2009 & 2007-2016 & 2016 \\
\hline \multicolumn{8}{|l|}{ Land-use change emissions ( $\left.E_{\mathrm{LUC}}\right)$} \\
\hline Bookkeeping methods & $1.4 \pm 0.7$ & $1.1 \pm 0.7$ & $1.2 \pm 0.7$ & $1.3 \pm 0.7$ & $1.2 \pm 0.7$ & $1.3 \pm 0.7$ & $1.3 \pm 0.7$ \\
\hline DGVMs & $1.3 \pm 0.5$ & $1.2 \pm 0.5$ & $1.2 \pm 0.4$ & $1.2 \pm 0.3$ & $1.2 \pm 0.4$ & $1.3 \pm 0.4$ & $1.4 \pm 0.8$ \\
\hline \multicolumn{8}{|l|}{ Terrestrial sink ( $\left.S_{\text {LAND }}\right)$} \\
\hline $\begin{array}{l}\text { Residual sink from global budget } \\
\left(E_{\mathrm{FF}}+E_{\mathrm{LUC}}-G_{\mathrm{ATM}}-S_{\text {OCEAN }}\right)\end{array}$ & $1.8 \pm 0.9$ & $1.8 \pm 0.9$ & $1.5 \pm 0.9$ & $2.6 \pm 0.9$ & $3.0 \pm 0.9$ & $3.6 \pm 1.0$ & $2.4 \pm 1.0$ \\
\hline DGVMS & $1.4 \pm 0.7$ & $2.4 \pm 0.6$ & $2.0 \pm 0.6$ & $2.5 \pm 0.5$ & $2.9 \pm 0.8$ & $3.0 \pm 0.8$ & $2.7 \pm 1.0$ \\
\hline \multicolumn{8}{|l|}{ Total land fluxes $\left(S_{\mathrm{LAND}}-E_{\mathrm{LUC}}\right)$} \\
\hline $\begin{array}{l}\text { Budget constraint } \\
\left(E_{\mathrm{FF}}-G_{\mathrm{ATM}}-S_{\mathrm{OCEAN}}\right)\end{array}$ & $0.4 \pm 0.5$ & $0.7 \pm 0.6$ & $0.4 \pm 0.6$ & $1.3 \pm 0.6$ & $1.7 \pm 0.6$ & $2.3 \pm 0.7$ & $1.1 \pm 0.7$ \\
\hline DGVMs & $0.1 \pm 0.9$ & $1.2 \pm 0.8$ & $0.7 \pm 0.7$ & $1.2 \pm 0.5$ & $1.7 \pm 0.8$ & $1.7 \pm 0.7$ & $1.3 \pm 1.0$ \\
\hline $\begin{array}{l}\text { Inversions (CTE/Jena } \\
\text { CarboScope/CAMS)* }\end{array}$ & $-1-1-$ & $-1-1-$ & $-1-/ 0.2$ & $-/ 0.6 / 1.3$ & $1.4 / 1.1 / 1.9$ & $1.8 / 1.4 / 2.3$ & $0.0 / 0.0 / 2.2$ \\
\hline
\end{tabular}

* Estimates are corrected for the pre-industrial influence of river fluxes (Sect. 2.7.2). See Tables A3 and 4 for references.

The uncertainty around the atmospheric growth rate is due to three main factors: first, the long-term reproducibility of reference gas standards (around $0.03 \mathrm{ppm}$ for $1 \sigma$ from the 1980s); second, the network composition of the marine boundary layer with some sites coming or going, gaps in the time series at each site, etc. (Dlugokencky and Tans, 2018) - the latter uncertainty was estimated by NOAA/ESRL with a Monte Carlo method by constructing 100 alternative networks (around 0.1 ppm; NOAA/ESRL, 2017; Masarie, and Tans, 1995); third, the uncertainty associated with using the average $\mathrm{CO}_{2}$ concentration from a surface network to approximate the true atmospheric average $\mathrm{CO}_{2}$ concentration (mass-weighted, in three dimensions) as needed to assess the total atmospheric $\mathrm{CO}_{2}$ burden. In reality these will differ, especially owing to the finite rates of vertical mixing and stratosphere-troposphere exchange. For example, excess $\mathrm{CO}_{2}$ from tropical emissions will arrive at stations in the network after a delay of months or more, and the signals will continue to evolve as the excess mixes throughout the troposphere and the stratosphere. The excess measured at the stations will not exactly track changes in total atmospheric burden, with offsets in magnitude and phasing. This effect must be very small on decadal and longer timescales, when the atmosphere can be considered well mixed. Preliminary estimates suggest this effect would increase the annual uncertainty, but a full analysis is not yet available. We therefore maintain an uncertainty around the annual growth rate based on the multiple stations data set ranges between 0.11 and $0.72 \mathrm{GtC} \mathrm{yr}^{-1}$, with a mean of $0.61 \mathrm{GtC} \mathrm{yr}^{-1}$ for 1959 1979 and $0.19 \mathrm{GtC} \mathrm{yr}^{-1}$ for 1980-2016, when a larger set of stations were available as provided by Dlugokencky and Tans (2018). We also maintain the uncertainty of the decadal averaged growth rate at $\pm 0.1 \mathrm{GtC} \mathrm{yr}^{-1}$ as in Le Queré et al. (2016) based on previous IPCC assessments, but recognising further exploration of this uncertainty is required.

We assign a high confidence to the annual estimates of $G_{\text {ATM }}$ because they are based on direct measurements from multiple and consistent instruments and stations distributed around the world (Ballantyne et al., 2012).

In order to estimate the total carbon accumulated in the atmosphere since 1750 or 1870 , we use an atmospheric $\mathrm{CO}_{2}$ concentration of $277 \pm 3$ or $288 \pm 3 \mathrm{ppm}$, respectively, based on a cubic spline fit to ice core data (Joos and Spahni, 2008). The uncertainty of $\pm 3 \mathrm{ppm}$ (converted to $\pm 1 \sigma$ ) is taken directly from the IPCC's assessment (Ciais et al., 2013). Typical uncertainties in the growth rate in atmospheric $\mathrm{CO}_{2}$ concentration from ice core data are equivalent to $\pm 0.1-0.15 \mathrm{GtC} \mathrm{yr}^{-1}$ as evaluated from the Law Dome data (Etheridge et al., 1996) for individual 20-year intervals over the period from 1870 to 1960 (Bruno and Joos, 1997).

\subsubsection{Growth rate projection}

We provide an assessment of $G_{\text {ATM }}$ for 2017 based on the observed increase in atmospheric $\mathrm{CO}_{2}$ concentration at the Mauna Loa station for January to September and monthly forecasts for October to December updated from Betts et al. (2016). The forecast uses a statistical relationship between annual $\mathrm{CO}_{2}$ growth rate and sea surface temperatures (SSTs) in the Niño3.4 region. The forecast SSTs from the 
GloSea seasonal forecast model were then used to estimate monthly $\mathrm{CO}_{2}$ concentrations at Mauna Loa throughout the following calendar year, assuming a stationary seasonal cycle. The forecast $\mathrm{CO}_{2}$ concentrations for January to August 2017 were close to the observations, so updating the 2017 forecast by simply averaging the observed and forecast values is considered justified. Growth at Mauna Loa is closely correlated with the global growth $(r=0.95)$ and is used here as a proxy for global growth.

\subsection{Ocean $\mathrm{CO}_{2}$ sink}

Estimates of the global ocean $\mathrm{CO}_{2}$ sink $S_{\text {OCEAN }}$ are from an ensemble of global ocean biogeochemistry models that meet observational constraints over the 1990s (see below). We use observation-based estimates of $S_{\text {OCEAN }}$ to provide a qualitative assessment of confidence in the reported results and to estimate the cumulative accumulation of $S_{\text {OCEAN }}$ over the pre-industrial period.

\subsubsection{Observation-based estimates}

We use the observational constraints assessed by IPCC of a mean ocean $\mathrm{CO}_{2}$ sink of $2.2 \pm 0.4 \mathrm{GtC} \mathrm{yr}^{-1}$ for the $1990 \mathrm{~s}$ (Denman et al., 2007) to verify that the GOBMs provide a realistic assessment of $S_{\text {OCEAN }}$. This is based on indirect observations and their spread, using the methods that are deemed most reliable for the assessment of this quantity. The IPCC did not revise its assessment in 2013. The observations are based on ocean-land $\mathrm{CO}_{2}$ sink partitioning from observed atmospheric $\mathrm{O}_{2} / \mathrm{N}_{2}$ concentration trends (Manning and Keeling, 2006; updated in Keeling and Manning, 2014), an oceanic inversion method constrained by ocean biogeochemistry data (Mikaloff Fletcher et al., 2006), and a method based on penetration timescale for CFCs (McNeil et al., 2003). This estimate is consistent with a range of methods (Wanninkhof et al., 2013). Here we use the IPCC confidence interval of $90 \%$ to avoid rejecting models that may be outliers but are still plausible.

We also use two estimates of the ocean $\mathrm{CO}_{2}$ sink and its variability based on interpolations of measurements of surface ocean fugacity of $\mathrm{CO}_{2}\left(p \mathrm{CO}_{2}\right.$ corrected for the nonideal behaviour of the gas; Pfeil et al., 2013). We refer to these as $p \mathrm{CO}_{2}$-based flux estimates. The measurements are from the Surface Ocean $\mathrm{CO}_{2}$ Atlas version 5, which is an update of version 3 (Bakker et al., 2016) and contains qualitycontrolled data to 2016 (see data attribution Table A4). The SOCAT v5 data were mapped using a data-driven diagnostic method (Rödenbeck et al., 2013) and a combined selforganising map and feed-forward neural network (Landschützer et al., 2014). The global $p \mathrm{CO}_{2}$-based flux estimates were adjusted to remove the pre-industrial ocean source of $\mathrm{CO}_{2}$ to the atmosphere of $0.45 \mathrm{GtC} \mathrm{yr}^{-1}$ from river input to the ocean (Jacobson et al., 2007), per our definition of

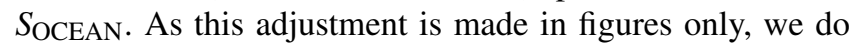

not account for the uncertainty in the river flux. Several other ocean sink products based on observations are also available, but they show large discrepancies with observed variability that need to be resolved. Here we used the two $p \mathrm{CO}_{2}$-based flux products that had the best fit to observations for their representation of tropical and global variability (Rödenbeck et al., 2015).

We further use results from two diagnostic ocean models of Khatiwala et al. (2013) and DeVries (2014) to estimate the anthropogenic carbon accumulated in the ocean prior to 1959. The two approaches assume constant ocean circulation and biological fluxes over the pre-industrial period, with $S_{\text {OCEAN }}$ estimated as a response in the change in atmospheric $\mathrm{CO}_{2}$ concentration calibrated to observations. The uncertainty in cumulative uptake of $\pm 20 \mathrm{GtC}$ (converted to $\pm 1 \sigma$ ) is taken directly from the IPCC's review of the literature (Rhein et al., 2013), or about $\pm 30 \%$ for the annual values (Khatiwala et al., 2009).

\subsubsection{Global ocean biogeochemistry models (GOBMs)}

The ocean $\mathrm{CO}_{2}$ sink for 1959-2016 is estimated using eight GOBMs (Table A2). All GOBMs fell within $90 \%$ confidence of the observed range, or 1.6 to $2.8 \mathrm{GtC} \mathrm{yr}^{-1}$ for the $1990 \mathrm{~s}$. The GOBMs represent the physical, chemical, and biological processes that influence the surface ocean concentration of $\mathrm{CO}_{2}$ and thus the air-sea $\mathrm{CO}_{2}$ flux. The GOBMs are forced by meteorological reanalysis and atmospheric $\mathrm{CO}_{2}$ concentration data available for the entire time period and mostly differ in the source of the atmospheric forcing data, spinup strategies, and in the resolution of the oceanic physical processes (Table A2). GOBMs do not include the effects of anthropogenic changes in nutrient supply, which could lead to an increase in the ocean sink of up to about $0.3 \mathrm{GtC} \mathrm{yr}^{-1}$ over the industrial period (Duce et al., 2008). They also do not include the perturbation associated with changes in river organic carbon, which is discussed Sect. 2.7.

The ocean $\mathrm{CO}_{2}$ sink for each GOBM is no longer normalised to the observations as in previous global carbon budgets (e.g. Le Quéré et al., 2016). The normalisation was mostly intended to ensure $S_{\text {LAND }}$ had a realistic mean value as it was previously estimated from the budget residual. With the introduction of the budget residual (Eq. 1) all terms can be estimated independently. Instead, the oceanic observations are used in the selection of the GOBMs, by using only the GOBMs that produce an oceanic $\mathrm{CO}_{2}$ sink over the $1990 \mathrm{~s}$ consistent with observations within $90 \%$ confidence intervals, as explained above.

\subsubsection{Uncertainty assessment for $S_{\text {OCEAN }}$}

The uncertainty around the mean ocean sink of anthropogenic $\mathrm{CO}_{2}$ was quantified by Denman et al. (2007) for the 1990s (see Sect. 2.4.1). To quantify the uncertainty around annual values, we examine the standard deviation 
of the GOBM ensemble, which averages between 0.2 and $0.3 \mathrm{GtC} \mathrm{yr}^{-1}$ during 1959-2017. We estimate that the uncertainty in the annual ocean $\mathrm{CO}_{2}$ sink is about $\pm 0.5 \mathrm{GtC} \mathrm{yr}^{-1}$ from the combined uncertainty of the mean flux based on observations of $\pm 0.4 \mathrm{GtC} \mathrm{yr}^{-1}$ and the standard deviation across GOBMs of up to $\pm 0.3 \mathrm{GtC} \mathrm{yr}^{-1}$, reflecting both the uncertainty in the mean sink from observations during the 1990s (Denman et al., 2007; Sect. 2.4.1) and in the interannual variability as assessed by GOBMs.

We examine the consistency between the variability of the model-based and the $p \mathrm{CO}_{2}$-based flux products to assess confidence in $S_{\text {OCEAN. }}$. The interannual variability of the ocean fluxes (quantified as the standard deviation) of the two $p \mathrm{CO}_{2}$-based products for 1986-2016 (where they overlap) is $\pm 0.35 \mathrm{GtC} \mathrm{yr}^{-1}$ (Rödenbeck et al., 2014) and $\pm 0.36 \mathrm{GtC} \mathrm{yr}^{-1}$ (Landschützer et al., 2015), compared to $\pm 0.27 \mathrm{GtC} \mathrm{yr}^{-1}$ for the normalised GOBM ensemble. The standard deviation includes a component of trend and decadal variability in addition to interannual variability, and their relative influence differs across estimates. The estimates generally produce a higher ocean $\mathrm{CO}_{2}$ sink during strong $\mathrm{El}$ Niño events. The annual $p \mathrm{CO}_{2}$-based flux products correlate with the ocean $\mathrm{CO}_{2}$ sink estimated here with a correlation of $r=0.75$ ( 0.49 to 0.84 for individual GOBMs) and $r=0.78$ ( 0.46 to 0.80 ) for the $p \mathrm{CO}_{2}$-based flux products of Rödenbeck et al. (2014) and Landschützer et al. (2015), respectively (simple linear regression), with their mutual correlation at 0.70 . The agreement between models and the flux products reflects some consistency in their representation of underlying variability since there is little overlap in their methodology or use of observations. The use of annual data for the correlation may reduce the strength of the relationship because the dominant source of variability associated with El Niño events is less than 1 year. We assess a medium confidence level to the annual ocean $\mathrm{CO}_{2}$ sink and its uncertainty because it is based on multiple lines of evidence, and the results are consistent in that the interannual variability in the GOBMs and data-based estimates are all generally small compared to the variability in the growth rate of atmospheric $\mathrm{CO}_{2}$ concentration.

\subsection{Terrestrial $\mathrm{CO}_{2}$ sink}

The terrestrial land sink ( $\left.S_{\text {LAND }}\right)$ is thought to be due to the combined effects of fertilisation by rising atmospheric $\mathrm{CO}_{2}$ and $\mathrm{N}$ deposition on plant growth, as well as the effects of climate change such as the lengthening of the growing season in northern temperate and boreal areas. $S_{\text {LAND }}$ does not include gross land sinks directly resulting from land use and land-use change (e.g. regrowth of vegetation) as these are part of the net land-use flux ( $\left.E_{\mathrm{LUC}}\right)$, although system boundaries make it difficult to exactly attribute $\mathrm{CO}_{2}$ fluxes on land between $S_{\text {LAND }}$ and $E_{\text {LUC }}$ (Erb et al., 2013).

New to the 2017 Global Carbon Budget, $S_{\text {LAND }}$ is estimated from the multi-model mean of the DGVMs (Ta- ble A1). As described in Sect. 2.2.3, DGVM simulations include all climate variability and $\mathrm{CO}_{2}$ effects over land. The DGVMs do not include the perturbation associated with changes in river organic carbon, which is discussed Sect. 2.7. We apply three criteria for minimum DGVM realism by including only those DGVMs with (1) steady state after spin up; (2) where available, net land fluxes ( $S_{\text {LAND }}-$ $\left.E_{\mathrm{LUC}}\right)$, that is a carbon sink over the 1990 s between -0.3 and $2.3 \mathrm{GtC} \mathrm{yr}^{-1}$, within $90 \%$ confidence of constraints by global atmospheric and oceanic observations (Keeling and Manning, 2014; Wanninkhof et al., 2013); and (3) global $E_{\mathrm{LUC}}$ that is a carbon source over the 1990s. Three DGVMs did not meet the criteria (1) for $E_{\mathrm{LUC}}$ because of an issue with the protocol and one did not meet the criteria (2).

The standard deviation of the annual $\mathrm{CO}_{2}$ sink across the DGVMs averages to $\pm 0.8 \mathrm{GtC} \mathrm{yr}^{-1}$ for the period 1959 to 2016. We attach a medium confidence level to the annual land $\mathrm{CO}_{2}$ sink and its uncertainty because the estimates from the residual budget and averaged DGVMs match well within their respective uncertainties (Table 5).

\subsection{The atmospheric perspective}

The worldwide network of atmospheric measurements can be used with atmospheric inversion methods to constrain the location of the combined total surface $\mathrm{CO}_{2}$ fluxes from all sources, including fossil and land-use change emissions and land and ocean $\mathrm{CO}_{2}$ fluxes. The inversions assume $E_{\mathrm{FF}}$ to be well known, and they solve for the spatial and temporal distribution of land and ocean fluxes from the residual gradients of $\mathrm{CO}_{2}$ between stations that are not explained by emissions.

Three atmospheric inversions (Table A3) used atmospheric $\mathrm{CO}_{2}$ data to the end of 2016 (including preliminary values in some cases) to infer the spatio-temporal $\mathrm{CO}_{2}$ flux field. We focus here on the largest and most consistent sources of information (namely the total $\mathrm{CO}_{2}$ flux over land regions and the distribution of the total land and ocean $\mathrm{CO}_{2}$ fluxes for the mid- to high-latitude Northern Hemisphere $(\mathrm{NH}), 30-90^{\circ} \mathrm{N}$; tropics, $30^{\circ} \mathrm{S}-30^{\circ} \mathrm{N}$; and mid- to high-latitude region of the Southern Hemisphere, 30-90 ${ }^{\circ} \mathrm{S}$ ) and use these estimates to comment on the consistency across various data streams and process-based estimates.

\section{Atmospheric inversions}

The three inversion systems used in this release are the CarbonTracker Europe (CTE; van der Laan-Luijkx et al., 2017), the Jena CarboScope (Rödenbeck, 2005), and CAMS (Chevallier et al., 2005). See Table A3 for version numbers. The three inversions are based on the same Bayesian inversion principles that interpret the same, for the most part, observed time series (or subsets thereof) but use different methodologies (Table A3). These differences mainly concern the selection of atmospheric $\mathrm{CO}_{2}$ data, the used prior fluxes, spatial breakdown (i.e. grid size), assumed correlation struc- 
tures, and mathematical approach. The details of these approaches are documented extensively in the references provided above. Each system uses a different transport model, which was demonstrated to be a driving factor behind differences in atmospherically based flux estimates, and specifically their distribution across latitudinal bands (Stephens et al., 2007).

The three inversions use atmospheric $\mathrm{CO}_{2}$ observations from various flask and in situ networks, as detailed in Table A3. They prescribe global $E_{\mathrm{FF}}$, which is scaled to the present study for CAMS and CTE, while CarboScope uses CDIAC extended after 2013 using the emission growth rate of the present study. Inversion results for the sum of natural ocean and land fluxes (Fig. 8) are more constrained in the Northern Hemisphere than in the tropics, because of the higher measurement station density in the NH. Results from atmospheric inversions, similar to the $p \mathrm{CO}_{2}$-based ocean flux products, are adjusted for the river fluxes. The atmospheric inversions provide new information on the regional distribution of fluxes.

\subsection{Processes not included in the global carbon budget}

The contribution of anthropogenic $\mathrm{CO}$ and $\mathrm{CH}_{4}$ to the global carbon budget has been partly neglected in Eq. (1) and is described in Sect. 2.7.1. The contribution of anthropogenic changes in river fluxes is conceptually included in Eq. (1) in $S_{\text {OCEAN }}$ and in $S_{\text {LAND }}$, but it is not represented in the process models used to quantify these fluxes. This effect is discussed in Sect. 2.7.2. Similarly, the loss of additional sink capacity from reduced forest cover is missing in the combination of approaches used here to estimate both land fluxes ( $E_{\mathrm{LUC}}$ and $S_{\text {LAND }}$ ) and its potential effect is discussed and quantified in Sect. 2.7.3.

\subsubsection{Contribution of anthropogenic $\mathrm{CO}$ and $\mathrm{CH}_{4}$ to the global carbon budget}

Equation (1) includes only partly the net input of $\mathrm{CO}_{2}$ to the atmosphere from the chemical oxidation of reactive carboncontaining gases from sources other than the combustion of fossil fuels, such as (1) cement process emissions, since these do not come from combustion of fossil fuels; (2) the oxidation of fossil fuels; and (3) the assumption of immediate oxidation of vented methane in oil production. However, it omits any other anthropogenic carbon-containing gases that are eventually oxidised in the atmosphere, such as anthropogenic emissions of $\mathrm{CO}$ and $\mathrm{CH}_{4}$. An attempt is made in this section to estimate their magnitude and identify the sources of uncertainty. Anthropogenic CO emissions are from incomplete fossil fuel and biofuel burning and deforestation fires. The main anthropogenic emissions of fossil $\mathrm{CH}_{4}$ that matter for the global carbon budget are the fugitive emissions of coal, oil, and gas upstream sectors (see below). These emissions of $\mathrm{CO}$ and $\mathrm{CH}_{4}$ contribute a net addition of fossil carbon to the atmosphere.

In our estimate of $E_{\mathrm{FF}}$ we assumed (Sect. 2.1.1) that all the fuel burned is emitted as $\mathrm{CO}_{2}$; thus, $\mathrm{CO}$ anthropogenic emissions associated with incomplete combustion and their atmospheric oxidation into $\mathrm{CO}_{2}$ within a few months are already counted implicitly in $E_{\mathrm{FF}}$ and should not be counted twice (same for $E_{\mathrm{LUC}}$ and anthropogenic $\mathrm{CO}$ emissions by deforestation fires). Anthropogenic emissions of fossil $\mathrm{CH}_{4}$ are not included in $E_{\mathrm{FF}}$, because these fugitive emissions are not included in the fuel inventories. Yet they contribute to the annual $\mathrm{CO}_{2}$ growth rate after $\mathrm{CH}_{4}$ gets oxidised into $\mathrm{CO}_{2}$. Anthropogenic emissions of fossil $\mathrm{CH}_{4}$ represent $15 \%$ of total $\mathrm{CH}_{4}$ emissions (Kirschke et al., 2013), that is $0.061 \mathrm{GtC} \mathrm{yr}^{-1}$ for the past decade. Assuming steady state, these emissions are all converted to $\mathrm{CO}_{2}$ by $\mathrm{OH}$ oxidation and thus explain $0.06 \mathrm{GtC} \mathrm{yr}^{-1}$ of the global $\mathrm{CO}_{2}$ growth rate in the past decade, or $0.07-0.1 \mathrm{GtC} \mathrm{yr}^{-1}$ using the higher $\mathrm{CH}_{4}$ emissions reported recently (Schwietzke et al., 2016).

Other anthropogenic changes in the sources of $\mathrm{CO}$ and $\mathrm{CH}_{4}$ from wildfires, biomass, wetlands, ruminants, or permafrost changes are similarly assumed to have a small effect on the $\mathrm{CO}_{2}$ growth rate. The $\mathrm{CH}_{4}$ emissions and sinks are published and analysed separately in the Global Methane Budget publication that follows a similar approach to that presented here (Saunois et al., 2016).

\subsubsection{Anthropogenic carbon fluxes in the land to ocean aquatic continuum}

The approach used to determine the global carbon budget refers to the mean, variations, and trends in the perturbation of $\mathrm{CO}_{2}$ in the atmosphere, referenced to the pre-industrial era. Carbon is continuously displaced from the land to the ocean through the land-ocean aquatic continuum (LOAC) comprising freshwaters, estuaries, and coastal areas (Bauer et al., 2013; Regnier et al., 2013). A significant fraction of this lateral carbon flux is entirely "natural" and is thus a steady state component of the pre-industrial carbon cycle. We account for this pre-industrial flux where appropriate in our study. However, changes in environmental conditions and land-use change have caused an increase in the lateral transport of carbon into the LOAC - a perturbation that is relevant for the global carbon budget presented here.

The results of the analysis of Regnier et al. (2013) can be summarised in two points of relevance for the anthropogenic $\mathrm{CO}_{2}$ budget. First, the anthropogenic perturbation has increased the organic carbon export from terrestrial ecosystems to the hydrosphere at a rate of $1.0 \pm 0.5 \mathrm{GtC} \mathrm{yr}^{-1}$, mainly owing to enhanced carbon export from soils. Second, this exported anthropogenic carbon is partly respired through the LOAC; partly sequestered in sediments along the LOAC; and, to a lesser extent, transferred in the open ocean where it may accumulate. The increase in storage of land-derived organic carbon in the LOAC and open ocean combined is es- 
timated by Regnier et al. (2013) at $0.65 \pm 0.35 \mathrm{GtC} \mathrm{yr}^{-1}$. We do not attempt to incorporate the changes in LOAC in our study.

The inclusion of freshwater fluxes of anthropogenic $\mathrm{CO}_{2}$ affects the estimates of, and partitioning between, $S_{\text {LAND }}$ and $S_{\text {OCEAN }}$ in Eq. (1) in complementary ways, but does not affect the other terms. This effect is not included in the GOBMs and DGVMs used in our global carbon budget analysis presented here.

\subsubsection{Loss of additional sink capacity}

The DGVM simulations now used to estimate $S_{\text {LAND }}$ are carried out with a time-invariant pre-industrial land-use mask. Hence, they overestimate the land sink by ignoring historical changes in vegetation cover due to land use and how this affected the global terrestrial biosphere's capacity to remove $\mathrm{CO}_{2}$ from the atmosphere. Historical land-cover change was dominated by transitions from vegetation types that can provide a large sink per area unit (typically forests) to others less efficient in removing $\mathrm{CO}_{2}$ from the atmosphere (typically croplands). The resultant decrease in land sink, called the "loss of sink capacity", is calculated as the difference between the actual land sink under changing land cover and the counterfactual land sink under pre-industrial land cover.

An efficient protocol has yet to be designed to estimate the magnitude of the loss of additional sink capacity in DGVMs. Here, we provide a quantitative estimate of this term to be used in the discussion. Our estimate uses the compact Earth system model OSCAR (Gasser et al., 2017), whose land carbon cycle component is designed to emulate the behaviour of TRENDY and CMIP5 complex models. We use OSCAR v2.2.1 (an update of v2.2, with minor changes) in a probabilistic setup identical to the one of Arneth et al. (2017) but with a Monte Carlo ensemble of 2000 simulations. For each, we calculate separately $S_{\text {LAND }}$ and the loss of additional sink capacity. We then constrain the ensemble by weighting each member to obtain a distribution of cumulative $S_{\text {LAND }}$ over 1850-2005 close to the DGVMs used here. From this ensemble, we estimate a loss of additional sink capacity of $0.4 \pm 0.3 \mathrm{GtC} \mathrm{yr}^{-1}$ on average over 2005-2014 and by extrapolation of $20 \pm 15 \mathrm{GtC}$ accumulated between 1870 and 2016.

\section{Results}

\subsection{Global carbon budget mean and variability for 1959-2016}

The global carbon budget averaged over the last half-century is shown in Fig. 3. For this time period, $82 \%$ of the total emissions $\left(E_{\mathrm{FF}}+E_{\mathrm{LUC}}\right)$ were caused by fossil fuels and industry and $18 \%$ by land-use change. The total emissions were partitioned among the atmosphere $(45 \%)$, ocean $(23 \%)$, and land $(32 \%)$. All components except land-use

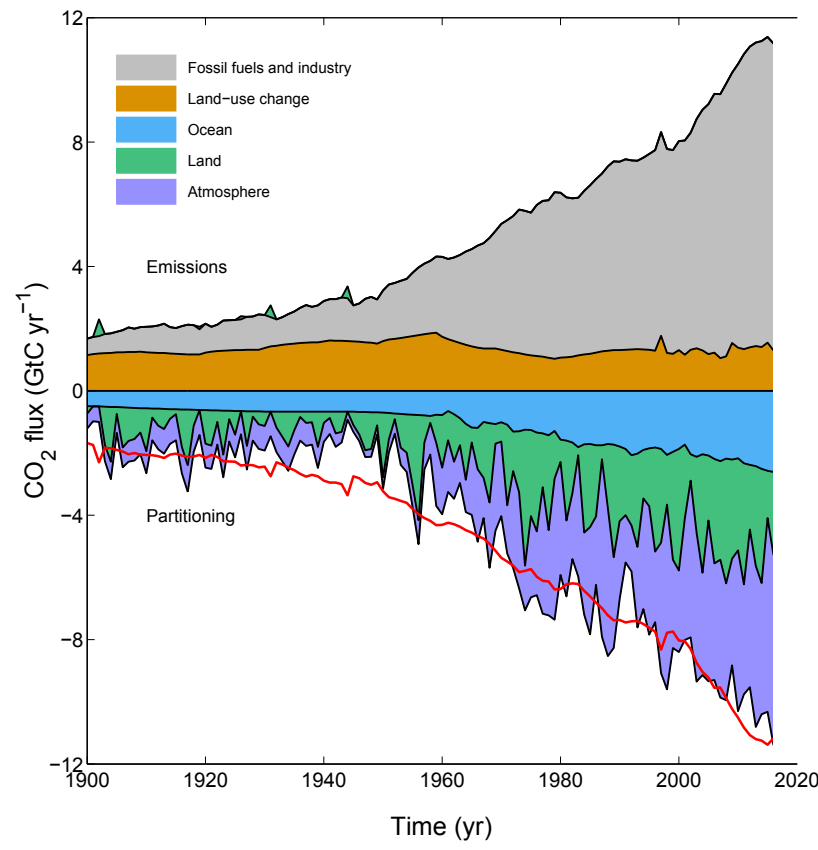

Figure 3. Combined components of the global carbon budget illustrated in Fig. 2 as a function of time, for emissions from fossil fuels and industry ( $E_{\mathrm{FF}}$; grey) and emissions from land-use change ( $E_{\mathrm{LUC}}$; brown), as well as their partitioning among the atmosphere $\left(G_{\mathrm{ATM}}\right.$; purple), land ( $S_{\mathrm{LAND}}$; green $)$, and oceans ( $S_{\mathrm{OCEAN}} ;$ blue $)$. The partitioning is based on nearly independent estimates from observations (for $G_{\mathrm{ATM}}$ ) and from process model ensembles constrained by data (for $S_{\text {OCEAN }}$ and $S_{\text {LAND }}$ ) and does not exactly add up to the sum of the emissions, resulting in a budget imbalance which is represented by the difference between the bottom red line (reflecting total emissions) and the sum of the ocean, land, and atmosphere. All time series are in $\mathrm{GtC} \mathrm{yr}^{-1}$. $G_{\text {ATM }}$ and $S_{\text {OCEAN }}$ prior to 1959 are based on different methods. $E_{\mathrm{FF}}$ is primarily from Boden et al. (2017) with uncertainty of about $\pm 5 \%( \pm 1 \sigma) ; E_{\mathrm{LUC}}$ are from two bookkeeping models (Table 2) with uncertainties of about $\pm 50 \%$; $G_{\text {ATM }}$ prior to 1959 is from Joos and Spahni (2008) with uncertainties equivalent to about $\pm 0.1-0.15 \mathrm{GtC} \mathrm{yr}^{-1}$, and from Dlugokencky and Tans (2018) from 1959 with uncertainties

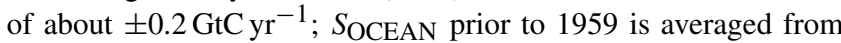
Khatiwala et al. (2013) and DeVries (2014) with uncertainty of about $\pm 30 \%$, and from a multi-model mean (Table 4) from 1959 with uncertainties of about $\pm 0.5 \mathrm{GtC} \mathrm{yr}^{-1} ; S_{\text {LAND }}$ is a multi-model mean (Table 4 ) with uncertainties of about $\pm 0.9 \mathrm{GtC} \mathrm{yr}^{-1}$. See the text for more details of each component and their uncertainties.

change emissions have grown since 1959, with important interannual variability in the growth rate in atmospheric $\mathrm{CO}_{2}$ concentration and in the land $\mathrm{CO}_{2}$ sink (Fig. 4), as well as some decadal variability in all terms (Table 6).

\subsection{1 $\mathrm{CO}_{2}$ emissions}

Global $\mathrm{CO}_{2}$ emissions from fossil fuels and industry have increased every decade from an average of $3.1 \pm 0.2 \mathrm{GtC} \mathrm{yr}^{-1}$ 
Table 6. Decadal mean in the five components of the anthropogenic $\mathrm{CO}_{2}$ budget for different periods and last year available. All values are

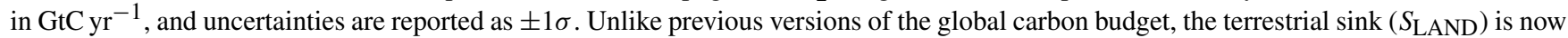
estimated independently from the mean of DGVM models. Therefore, the table also shows the budget imbalance ( $\left.B_{\mathrm{IM}}\right)$, which provides a measure of the discrepancies among the nearly independent estimates and has an uncertainty exceeding $\pm 1 \mathrm{GtC}^{-1}$. A positive imbalance means the emissions are overestimated and/or the sinks are too small.

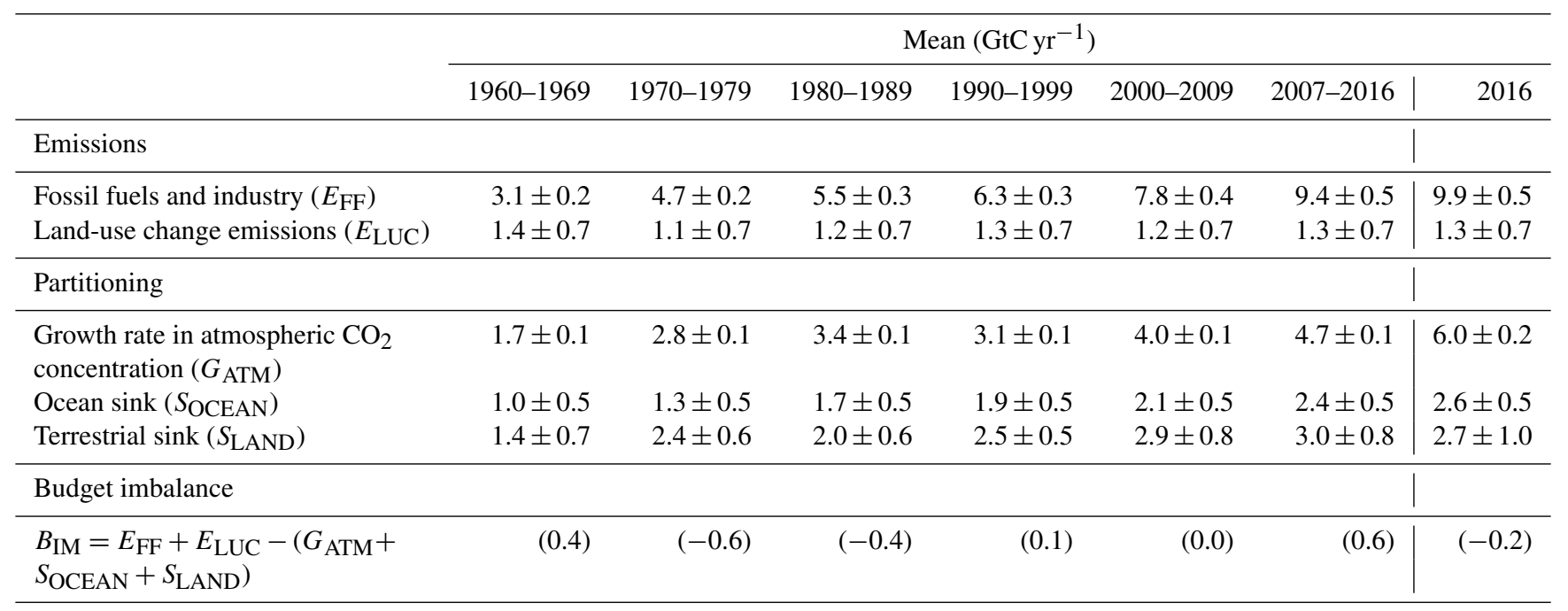

in the 1960 s to an average of $9.4 \pm 0.5 \mathrm{GtC} \mathrm{yr}^{-1}$ during 2007-2016 (Table 6 and Fig. 5). The growth rate in these emissions decreased between the 1960s and the 1990s, from $4.5 \% \mathrm{yr}^{-1}$ in the $1960 \mathrm{~s}(1960-1969)$ to $2.8 \% \mathrm{yr}^{-1}$ in the 1970s (1970-1979), $1.9 \% \mathrm{yr}^{-1}$ in the 1980s (1980-1989), and $1.1 \% \mathrm{yr}^{-1}$ in the 1990s (1990-1999). After this period, the growth rate began increasing again in the 2000s at an average growth rate of $3.3 \% \mathrm{yr}^{-1}$, decreasing to $1.8 \% \mathrm{yr}^{-1}$ for the last decade (2007-2016) and to $+0.4 \% \mathrm{yr}^{-1}$ during 2014-2016.

In contrast, $\mathrm{CO}_{2}$ emissions from land use, land-use change, and forestry have remained relatively constant, at around $1.3 \pm 0.7 \mathrm{GtC} \mathrm{yr}^{-1}$ over the past half-century, in agreement with the DGVM ensemble of models. However, there is no agreement on the trend over the full period, with two bookkeeping models suggesting opposite trends and no coherence among DGVMs (Fig. 6).

\subsubsection{Partitioning among the atmosphere, ocean, and land}

The growth rate in atmospheric $\mathrm{CO}_{2}$ level increased from $1.7 \pm 0.1 \mathrm{GtC} \mathrm{yr}^{-1}$ in the 1960 s to $4.7 \pm 0.1 \mathrm{GtC} \mathrm{yr}^{-1}$ during 2007-2016 with important decadal variations (Table 6). Both ocean and land $\mathrm{CO}_{2}$ sinks increased roughly in line with the atmospheric increase, but with significant decadal variability on land (Table 6) and possibly in the ocean (Fig. 7).

The ocean $\mathrm{CO}_{2}$ sink increased from $1.0 \pm 0.5 \mathrm{GtC} \mathrm{yr}^{-1}$ in the 1960 s to $2.4 \pm 0.5 \mathrm{GtC} \mathrm{yr}^{-1}$ during 2007-2016, with interannual variations of the order of a few tenths of ${\mathrm{GtC} \mathrm{yr}^{-1}}^{-1}$ generally showing an increased ocean sink during large $\mathrm{El}$ Niño events (i.e. 1997-1998) (Fig. 7; Rödenbeck et al.,
2014). Note the lower ocean sink estimate compared to previous global carbon budget releases is due to the fact that ocean models are no longer normalised to observations. Although there is some coherence among the GOBMs and $p \mathrm{CO}_{2}$-based flux products regarding the mean, there is poor agreement for interannual variability and the ocean models underestimate decadal variability (Sect. 2.4.3 and Fig. 7, also see new data-based decadal estimate of DeVries et al., 2017).

The terrestrial $\mathrm{CO}_{2}$ sink increased from $1.4 \pm 0.7 \mathrm{GtC} \mathrm{yr}^{-1}$ in the $1960 \mathrm{~s}$ to $3.0 \pm 0.8 \mathrm{GtC} \mathrm{yr}^{-1}$ during 2007-2016, with important interannual variations of up to $2 \mathrm{GtC} \mathrm{yr}^{-1}$ generally showing a decreased land sink during El Niño events, overcompensating for the increase in ocean sink and responsible for the enhanced growth rate in atmospheric $\mathrm{CO}_{2}$ concentration during El Niño events (Fig. 6). The larger land $\mathrm{CO}_{2}$ sink during 2007-2016 compared to the 1960 s is reproduced by all the DGVMs in response to the combined atmospheric $\mathrm{CO}_{2}$ increase and changes in climate and is consistent with constraints from the other budget terms (Table 5).

The total $\mathrm{CO}_{2}$ fluxes on land $\left(S_{\mathrm{LAND}}-E_{\mathrm{LUC}}\right)$ constrained by the atmospheric inversions show in general very good agreement with the global budget estimate, as expected given the strong constraints of $G_{\mathrm{ATM}}$ and the small relative uncertainty assumed on $S_{\mathrm{OCEAN}}$ and $E_{\mathrm{FF}}$ by inversions. The total land flux is of similar magnitude for the decadal average, with estimates for 2007-2016 from the three inversions of $1.8,1.4$, and $2.3 \mathrm{GtC} \mathrm{yr}^{-1}$ compared to $1.7 \pm 0.7 \mathrm{GtC} \mathrm{yr}^{-1}$ from the DGVMs and $2.3 \pm 0.7 \mathrm{GtC} \mathrm{yr}^{-1}$ for the total flux computed with the carbon budget constraints (Table 5). 

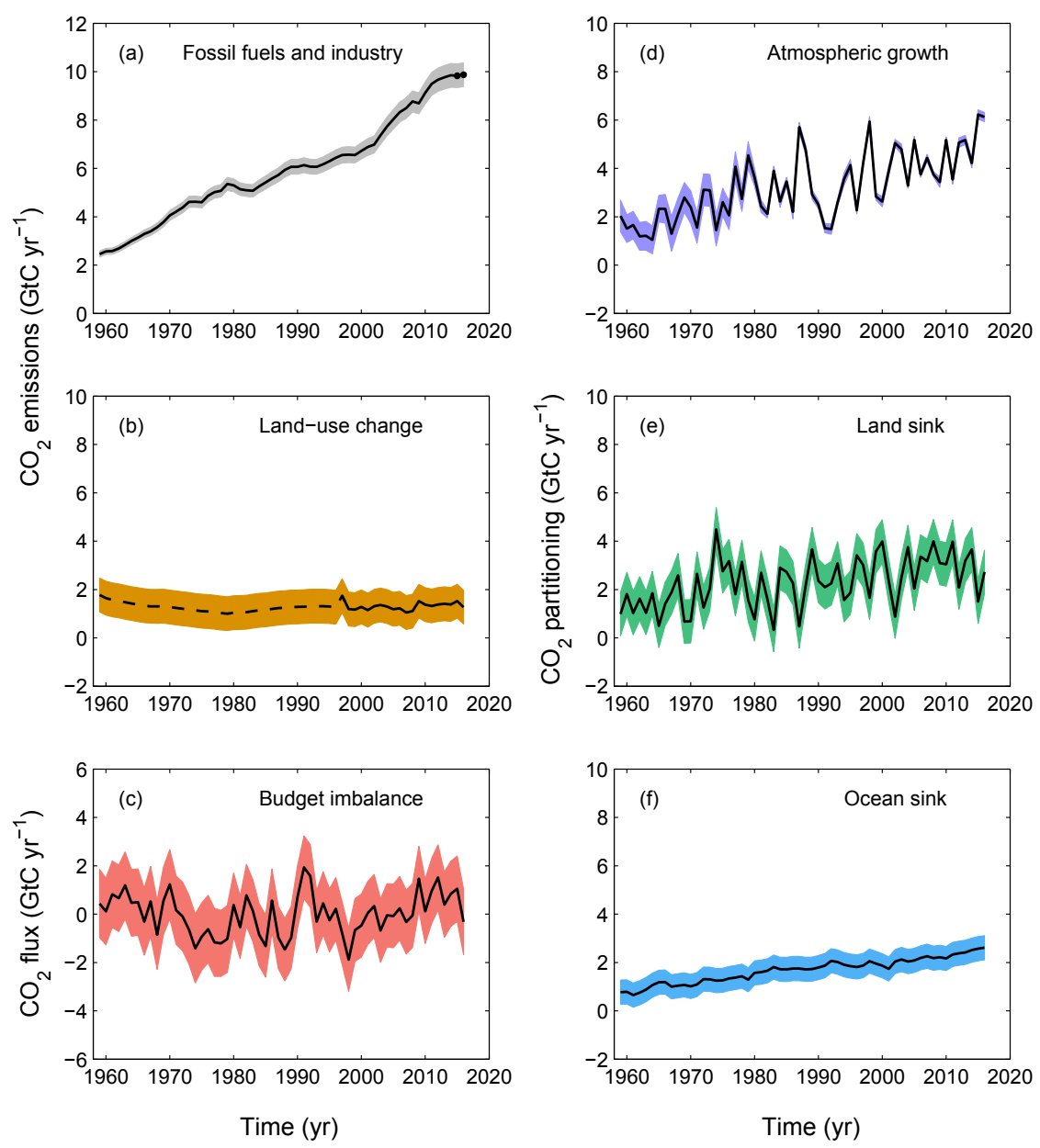

Figure 4. Components of the global carbon budget and their uncertainties as a function of time, presented individually for (a) emissions from fossil fuels and industry $\left(E_{\mathrm{FF}}\right)$, (b) emissions from land-use change $\left(E_{\mathrm{LUC}}\right)$, (c) the budget imbalance that is not accounted for by the other terms, $(\mathbf{d})$ the growth rate in atmospheric $\mathrm{CO}_{2}$ concentration $\left(G_{\mathrm{ATM}}\right)$, and $(\mathbf{e})$ the land $\mathrm{CO}_{2} \operatorname{sink}\left(S_{\mathrm{LAND}}\right.$; positive indicates a flux from the atmosphere to the land), (f) the ocean $\mathrm{CO}_{2} \operatorname{sink}\left(S_{\text {OCEAN }}\right.$; positive indicates a flux from the atmosphere to the ocean). All time series are

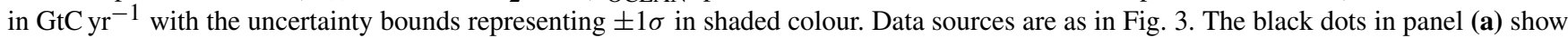
values for 2015 and 2016 that originate from a different data set to the remainder of the data (see text). The dashed line in panel (b) identifies the pre-satellite period before the inclusion of peatland burning.

\subsubsection{Budget imbalance}

The carbon budget imbalance ( $B_{\mathrm{IM}}$; Eq. 1$)$ quantifies the mismatch between the estimated total emissions and the estimated changes in the atmosphere, land, and ocean reservoirs. The mean budget imbalance from 1959 to 2016 is very small $\left(0.07 \mathrm{GtC} \mathrm{yr}^{-1}\right)$ and shows no trend over the full time series. The process models (GOBMs and DGVMs) have been selected to match observational constraints in the 1990s but no further constraints have been applied to their representation of trend and variability. Therefore, the near-zero mean and trend in the budget imbalance are indirect evidence of a coherent community understanding of the emissions and their partitioning on those timescales (Fig. 4). However, the budget imbalance shows substantial variability of the order of $\pm 1 \mathrm{GtC} \mathrm{yr}^{-1}$, particularly over semi-decadal timescales, although most of the variability is within the uncertainty of the estimates. The imbalance during the 1960s, early 1990s, and in the last decade suggests that either the emissions were overestimated or the sinks were underestimated during these periods. The reverse is true for the 1970s and around 19952000 (Fig. 3).

We cannot attribute the cause of the variability in the budget imbalance with our analysis - we can only note that the budget imbalance is unlikely to be explained by errors or biases in the emissions alone because of its large semidecadal variability component, a variability that is untypical of emissions (Fig. 4). Errors in $S_{\text {LAND }}$ and $S_{\text {OCEAN }}$ are more likely to be the main cause for the budget imbalance. For example, underestimation of the $S_{\text {LAND }}$ by DGVMs has 

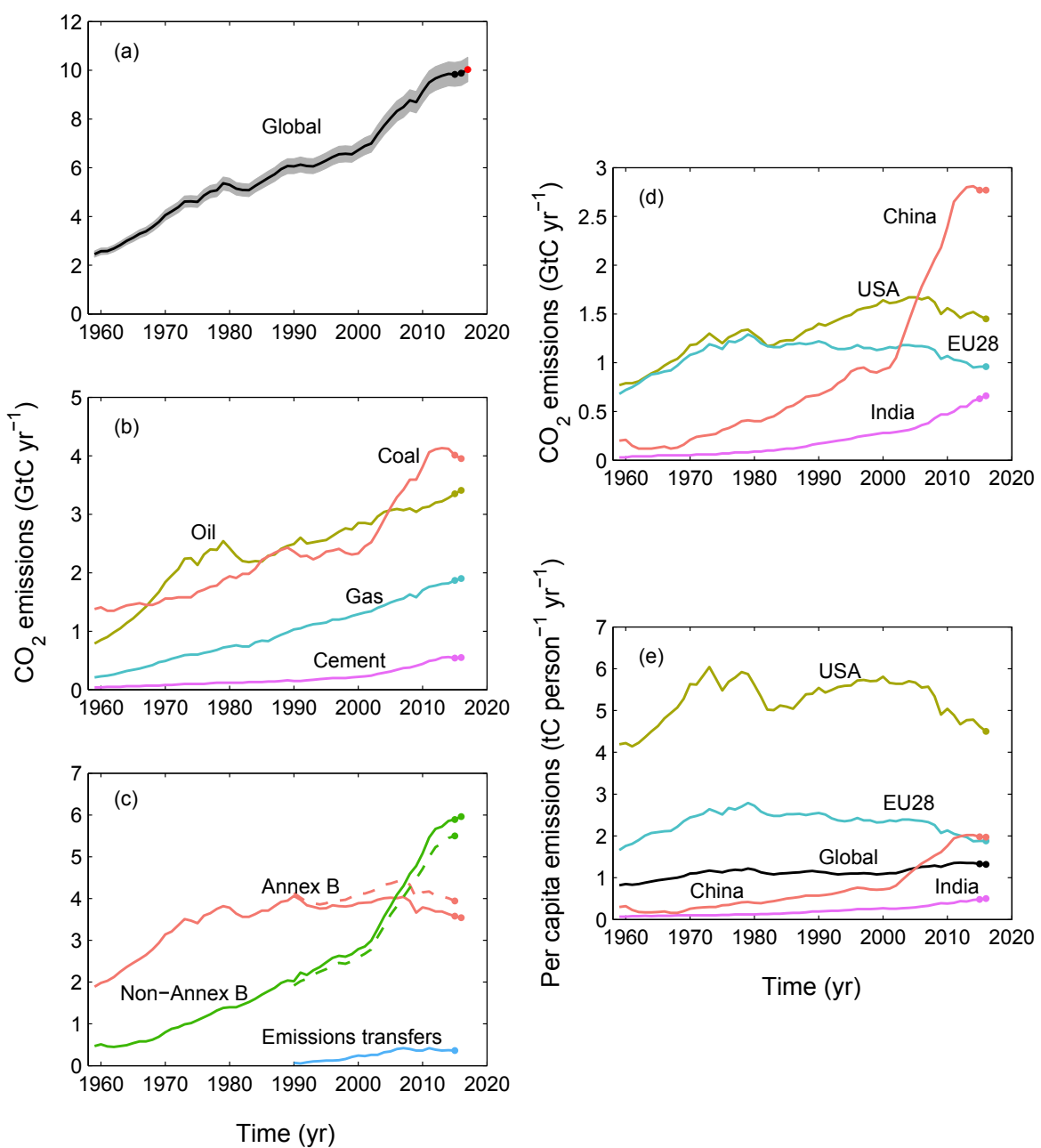

Figure 5. $\mathrm{CO}_{2}$ emissions from fossil fuels and industry for (a) the globe, including an uncertainty of $\pm 5 \%$ (grey shading), the emissions extrapolated using BP energy statistics (black dots), and the emissions projection for year 2017 based on GDP projection (red dot); (b) global emissions by fuel type, including coal (salmon), oil (olive), gas (turquoise), and cement (purple), and excluding gas flaring which is small ( $0.6 \%$ in 2013); (c) territorial (solid line) and consumption (dashed line) emissions for the countries listed in Annex B of the Kyoto Protocol (salmon lines; mostly advanced economies with emissions limitations) versus non-Annex B countries (green lines) - also shown are the emissions transfer from non-Annex B to Annex B countries (light blue line); (d) territorial $\mathrm{CO}_{2}$ emissions for the top three country emitters (USA - olive; China - salmon; India - purple) and for the European Union (EU; turquoise for the 28 member states of the EU as of 2012), and (e) per-capita emissions for the top three country emitters and the EU (all colours as in panel d) and the world (black). In panels (b-e); the dots show the data that were extrapolated from BP energy statistics for 2014 and 2015 . All time series are in $\mathrm{GtC}^{-1} \mathrm{except}^{-1}$ the percapita emissions (e), which are in tonnes of carbon per person per year ( $\mathrm{tC}$ person ${ }^{-1} \mathrm{yr}^{-1}$ ). Territorial emissions are primarily from Boden et al. (2017) except national data for the USA and EU28 (the 28 member states of the EU) for 1990-2014, which are reported by the countries to the UNFCCC as detailed in the text; consumption-based emissions are updated from Peters et al. (2011a). See Sect. 2.1.1 for details of the calculations and data sources.

been reported following the eruption of Mount Pinatubo in 1991 possibly due to missing responses to changes in diffuse radiation (Mercado et al., 2009) or other yet unknown factors, and DGVMs are suspected to overestimate the land sink in response to the wet decade of the 1970s (Sitch et al., 2003). Decadal and semi-decadal variability in the ocean sink has been also reported recently (DeVries et al., 2017; Landschützer et al., 2015), with the $p \mathrm{CO}_{2}$-based ocean flux products suggesting a smaller-than-expected ocean $\mathrm{CO}_{2}$ sink in the 1990s and a larger-than-expected sink in the 2000s (Fig. 7), possibly caused by changes in ocean circulation (DeVries et al., 2017) not captured in coarse-resolution GOBMs used here (Dufour et al., 2013). 

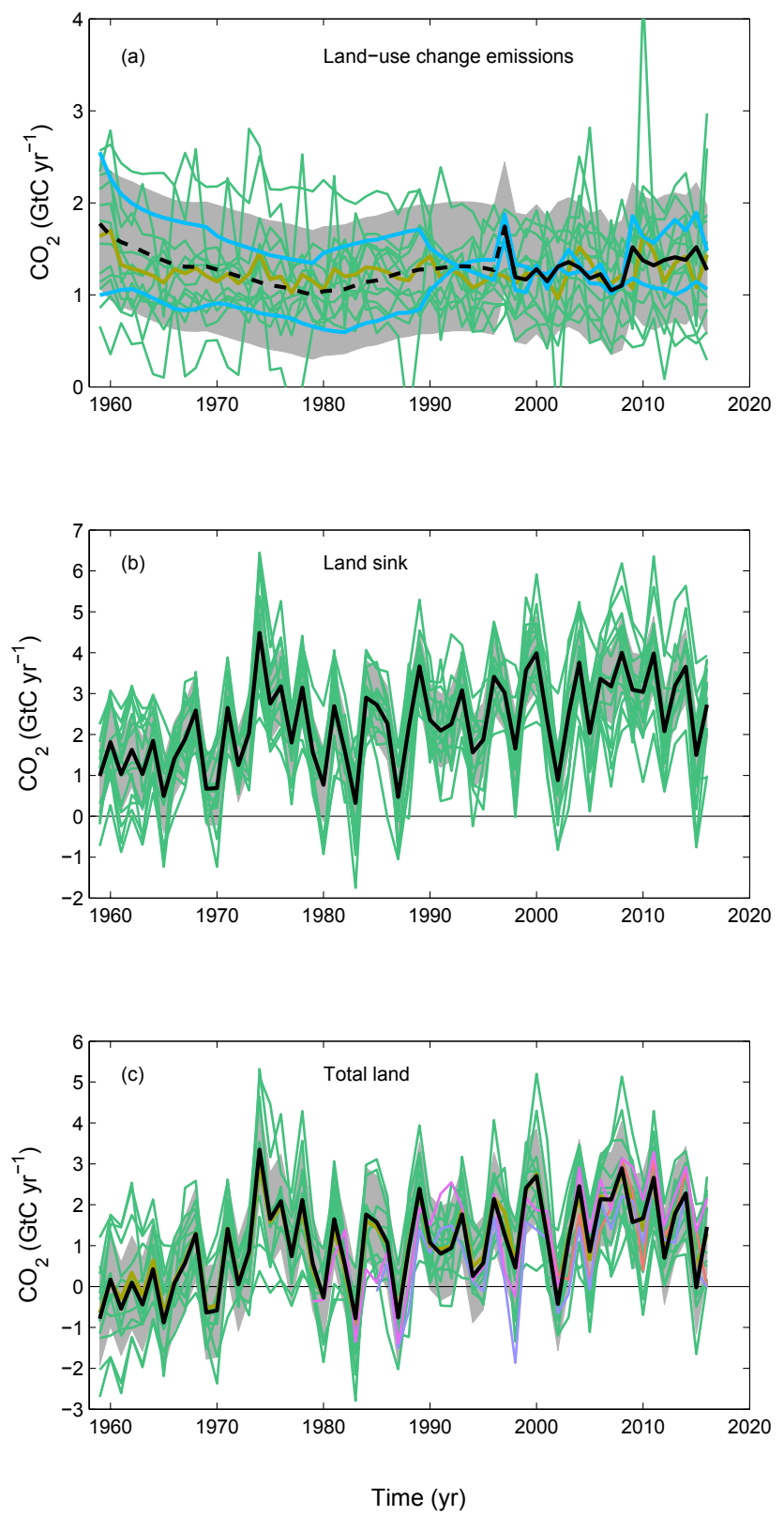

Figure 6. $\mathrm{CO}_{2}$ exchanges between the atmosphere and the terrestrial biosphere as used in the global carbon budget (black with $\pm 1 \sigma$ uncertainty in grey shading) for (a) $\mathrm{CO}_{2}$ emissions from land-use change $\left(E_{\mathrm{LUC}}\right)$, showing also individually the two bookkeeping models (two blue lines) and the DGVM model results (green) and their multi-model mean (olive). The dashed line identifies the presatellite period before the inclusion of peatland burning, (b) land $\mathrm{CO}_{2}$ sink ( $S_{\text {LAND }}$ ) with individual DGVMs (green), and (c) total land $\mathrm{CO}_{2}$ fluxes (b minus a) with individual DGVMs (green) and their multi-model mean (olive) and atmospheric inversions (CAMS in purple, Jena CarboScope in pink, CTE in salmon; see details in Table 4). In panel (c) the inversions were adjusted for the preindustrial land sink of $\mathrm{CO}_{2}$ from river input, by removing a sink of $0.45 \mathrm{GtC} \mathrm{yr}^{-1}$ (Jacobson et al., 2007), but not for the anthropogenic contribution to river fluxes (see Sect. 2.7.2).

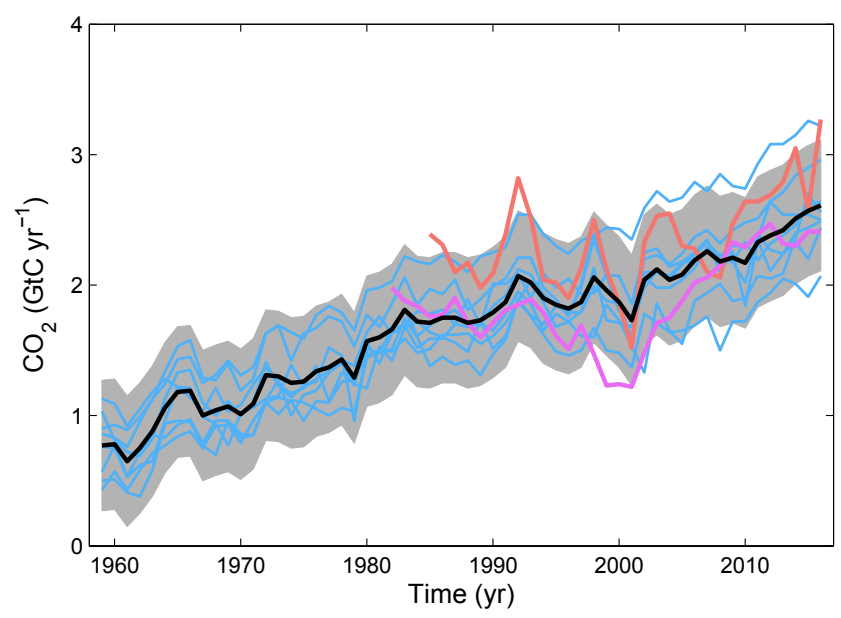

Figure 7. Comparison of the anthropogenic atmosphere-ocean $\mathrm{CO}_{2}$ flux showing the budget values of $S_{\text {OCEAN }}$ (black; with $\pm 1 \sigma$ uncertainty in grey shading), individual ocean models (blue), and the two ocean $p \mathrm{CO}_{2}$-based flux products (Rödenbeck et al., 2014, in salmon and Landschützer et al., 2015, in pink; see Table 4). Both $p \mathrm{CO}_{2}$-based flux products were adjusted for the pre-industrial ocean source of $\mathrm{CO}_{2}$ from river input to the ocean, which is not present in the ocean models, by adding a sink of $0.45 \mathrm{GtC} \mathrm{yr}^{-1}$ (Jacobson et al., 2007) to make them comparable to $S_{\text {OCEAN }}$. This adjustment does not take into account the anthropogenic contribution to river fluxes (see Sect. 2.7.2).

\subsubsection{Regional distribution}

Figure 8 shows the partitioning of the total surface fluxes excluding emissions from fossil fuels and industry $\left(S_{\text {LAND }}+\right.$ $\left.S_{\text {OCEAN }}-E_{\mathrm{LUC}}\right)$ according to the multi-model average of the process models in the ocean and on land (GOBMs and DGVMs) and to the three atmospheric inversions. The total surface fluxes provide information on the regional distribution of those fluxes by latitude bands (Fig. 8). The global mean $\mathrm{CO}_{2}$ fluxes from process models for 2007-2016 is $4.1 \pm 1.0 \mathrm{GtC} \mathrm{yr}^{-1}$. This is comparable to the fluxes of $4.6 \pm 0.5 \mathrm{GtC} \mathrm{yr}^{-1}$ inferred from the remainder of the carbon budget $\left(E_{\mathrm{FF}}-G_{\mathrm{ATM}}\right.$ in Eq. 1; Table 6) within their respective uncertainties. The total $\mathrm{CO}_{2}$ fluxes from the three inversions range between 4.1 and $5.0 \mathrm{GtC} \mathrm{yr}^{-1}$, consistent with the carbon budget as expected from the constraints on the inversions.

In the south (south of $30^{\circ} \mathrm{S}$ ), the atmospheric inversions and process models all suggest a $\mathrm{CO}_{2}$ sink for 2007-2016 around $1.3-1.4 \mathrm{GtC} \mathrm{yr}^{-1}$ (Fig. 8), although interannual to decadal variability is not fully consistent across methods. The interannual variability in the south is low because of the dominance of ocean area with low variability compared to land areas.

In the tropics $\left(30^{\circ} \mathrm{S}-30^{\circ} \mathrm{N}\right)$, both the atmospheric inversions and process models suggest the carbon balance in this region is close to neutral on average over the past 

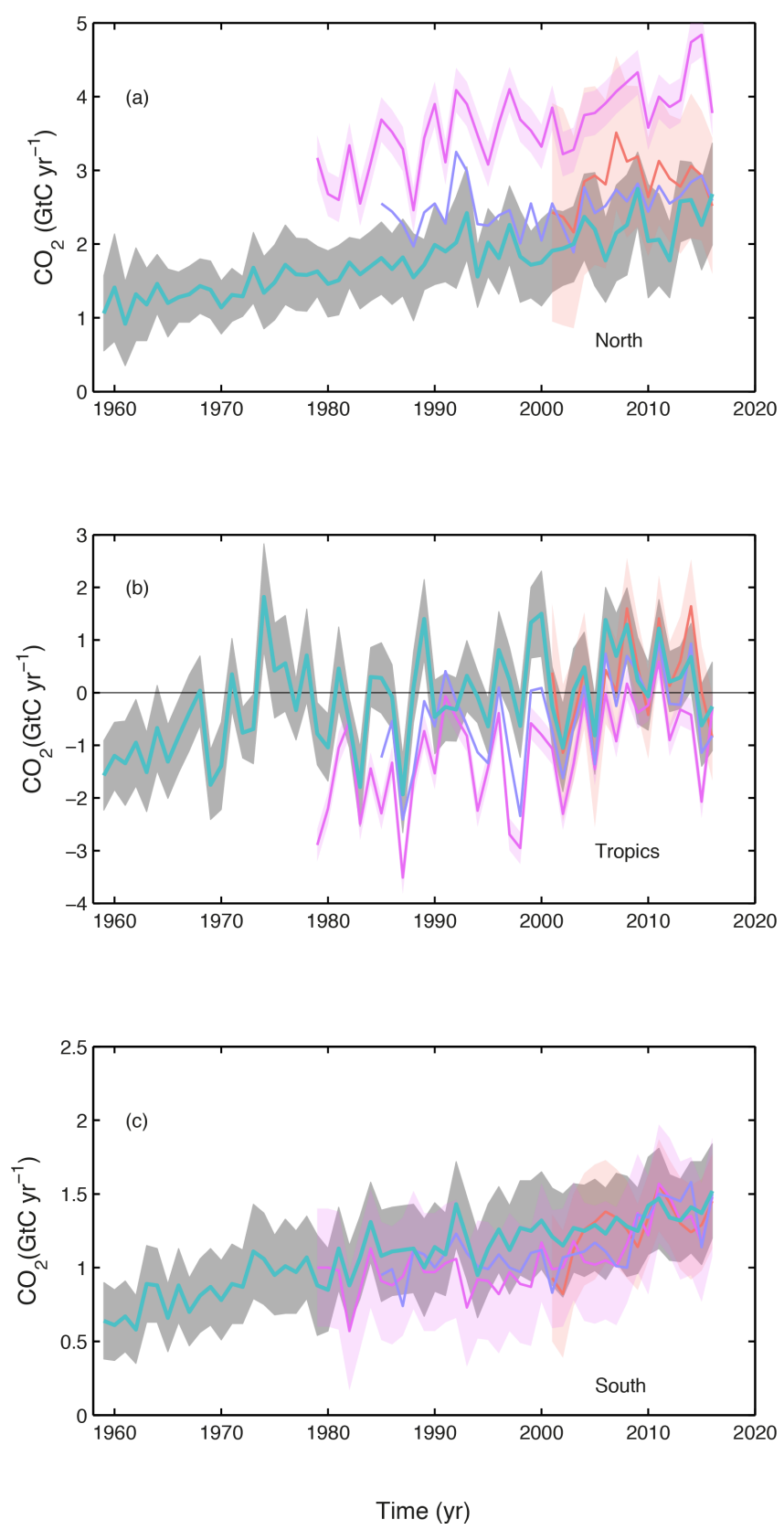

Figure 8. $\mathrm{CO}_{2}$ fluxes between the atmosphere and the surface $\left(S_{\text {OCEAN }}+S_{\text {LAND }}-E_{\text {LUC }}\right)$ by latitude bands for the (a) north (north of $30^{\circ} \mathrm{N}$ ), (b) tropics $\left(30^{\circ} \mathrm{S}-30^{\circ} \mathrm{N}\right.$ ), and (c) south (south of $30^{\circ} \mathrm{S}$ ). Estimates from the combination of the process models for the land and oceans are shown (turquoise) with $\pm 1 \sigma$ of the model ensemble (in grey). Results from the three atmospheric inversions are also shown (CAMS in purple, Jena CarboScope in pink, CTE in salmon; references and version number in Table 4). Where available the uncertainty in the inversions are also shown. Positive values indicate a flux from the atmosphere to the land and/or ocean.

decade, with fluxes for 2007-2016 ranging between -0.5

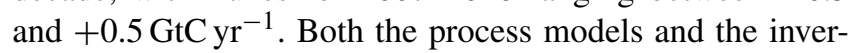
sions consistently allocate more year-to-year variability of
$\mathrm{CO}_{2}$ fluxes to the tropics compared to the north (north of $30^{\circ} \mathrm{N}$; Fig. 8), with this variability being dominated by land fluxes.

In the north (north of $30^{\circ} \mathrm{N}$ ), the inversions and process models are not in agreement on the magnitude of the $\mathrm{CO}_{2}$ sink, with the ensemble mean of the process models suggesting a total Northern Hemisphere sink for 2007-2016 of $2.3 \pm 0.6 \mathrm{GtC} \mathrm{yr}^{-1}$, below the estimates from the three inversions that estimate a sink of $2.7,3.0$, and $4.1 \mathrm{GtC} \mathrm{yr}^{-1}$ (Fig. 8). The mean difference can only partly be explained by the influence of river fluxes, which is seen by the inversions but not included in the process models; this flux in the Northern Hemisphere would be less than $0.45 \mathrm{GtC} \mathrm{yr}^{-1}$ because only the anthropogenic contribution to river fluxes needs to be accounted for. The CTE and Jena CarboScope inversions are within the 1 standard deviation of the process models for the mean sink during their overlap period, while the CAMS inversion gives a higher sink in the north than the process models and a correspondingly higher source in the tropics.

Differences between CTE, CAMS, and Jena CarboScope may be related, for example, to differences in their interhemispheric transport and other inversion settings (Table A3). Separate analysis has shown that the influence of the chosen prior land and ocean fluxes is minor compared to other aspects of each inversion. In comparison to the previous global carbon budget publication, the fossil fuel inputs for CarboScope changed to lower emissions in the north compared to CTE and CAMS, resulting in a smaller northern sink for CarboScope compared to the previous estimate. Differences between the mean fluxes of CAMS in the north and the ensemble of process models cannot be simply explained. They could either reflect a bias in this inversion or missing processes or biases in the process models, such as the lack of adequate parameterisations for forest management in the north and for forest degradation emissions in the tropics for the DGVMs. The estimated contribution of the north and its uncertainty from process models is sensitive both to the ensemble of process models used and to the specifics of each inversion.

\subsection{Global carbon budget for the last decade (2007-2016)}

The global carbon budget averaged over the last decade (2007-2016) is shown in Fig. 2. For this time period, $88 \%$ of the total emissions $\left(E_{\mathrm{FF}}+E_{\mathrm{LUC}}\right)$ were from fossil fuels and industry $\left(E_{\mathrm{FF}}\right)$ and $12 \%$ from land-use change $\left(E_{\mathrm{LUC}}\right)$. The total emissions were partitioned among the atmosphere $(44 \%)$, ocean $(22 \%)$, and land $(28 \%)$, with a remaining unattributed budget imbalance (5\%).

\subsection{1 $\mathrm{CO}_{2}$ emissions}

Global $\mathrm{CO}_{2}$ emissions from fossil fuels and industry grew at a rate of $1.8 \% \mathrm{yr}^{-1}$ for the last decade (2007-2016), 
slowing down to $+0.4 \% \mathrm{yr}^{-1}$ during 2014-2016. China's emissions increased by $+3.8 \% \mathrm{yr}^{-1}$ on average (increasing by $+1.7 \mathrm{GtC} \mathrm{yr}^{-1}$ during the 10 -year period) dominating the global trends, followed by India's emissions increase by $+5.8 \% \mathrm{yr}^{-1}$ (increasing by $+0.30 \mathrm{GtC} \mathrm{yr}^{-1}$ ), while emissions decreased in EU28 by $2.2 \% \mathrm{yr}^{-1}$ (decreasing by $-0.23 \mathrm{GtC} \mathrm{yr}^{-1}$ ) and in the USA by $1.0 \% \mathrm{yr}^{-1}$ (decreasing

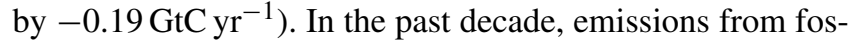
sil fuels and industry decreased significantly (at the $95 \%$ level) in 26 countries. A total of 21 of these countries had positive growth in GDP over the same time period, representing $21 \%$ of global emissions (Croatia, Czech Republic, Denmark, France, Germany, Greece, Ireland, Jamaica, Latvia, Luxembourg, Malta, Poland, Romania, Serbia, Slovakia, Slovenia, Sweden, Switzerland, Ukraine, United Kingdom, USA), while 5 countries had both declining GDP and emissions (Andorra, Aruba, North Korea, Greenland, and Syria).

In contrast, there is no apparent trend in $\mathrm{CO}_{2}$ emissions from land-use change (Fig. 6), though the data are very uncertain.

\subsubsection{Partitioning among the atmosphere, ocean, and land}

The growth rate in atmospheric $\mathrm{CO}_{2}$ concentration was initially constant and then increased during the later part of the decade 2007-2016, reflecting a similar constant level followed by a decrease in the land sink, albeit with large interannual variability (Fig. 4). During the same period, the ocean $\mathrm{CO}_{2}$ sink appears to have intensified, an effect which is particularly apparent in the $p \mathrm{CO}_{2}$-based flux products (Fig. 7) and is thought to originate at least in part in the Southern Ocean (Landschützer et al., 2015).

\subsubsection{Budget imbalance}

The budget imbalance was $0.6 \mathrm{GtC} \mathrm{yr}^{-1}$ on average over 2007-2016. Although the uncertainties are large in each term, the sustained imbalance over a decade suggests an overestimation of the emissions and/or an underestimation of the sinks. Such a large imbalance is unlikely to originate from the emissions alone because it would indicate sustained bias in emissions over a 10-year period that is as large as the $1 \sigma$ uncertainty. An origin in the land and/or ocean sink is more likely, given the large variability of the land sink and the suspected underestimation of decadal variability in the ocean sink. More integrated use of observations in the global carbon budget, either on their own or for further constraining model results, should help resolve some of the budget imbalance (Peters et al., 2017; Sect. 4).

\subsection{Global carbon budget for year 2016}

\subsection{1 $\mathrm{CO}_{2}$ emissions}

Preliminary estimates of global $\mathrm{CO}_{2}$ emissions from fossil fuels and industry based on BP energy statistics are for emissions remaining nearly constant between 2015 and 2016 at $9.9 \pm 0.5 \mathrm{GtC}$ in 2016 (Fig. 5), distributed among coal (40\%), oil (34\%), gas (19\%), cement $(5.6 \%)$, and gas flaring $(0.7 \%)$. Compared to the previous year, emissions from coal decreased by $-1.7 \%$, while emissions from oil, gas, and cement increased by $1.5,1.5$, and $1.0 \%$, respectively. All growth rates presented are adjusted for the leap year, unless stated otherwise.

Emissions in 2016 were $0.2 \%$ higher than in 2015, continuing the low growth trends observed in 2014 and 2015. This growth rate is as projected in Le Quéré et al. (2016) based on national emissions projections for China and the USA and projections of gross domestic product corrected for $I_{\mathrm{FF}}$ trends for the rest of the world. The specific projection for 2016 for China made last year of $-0.5 \%$ (range of -3.8 to $+1.3 \%$ ) is within the uncertainty of the realised growth rate of $-0.3 \%$. Similarly, the projected growth for the US of $-1.7 \%$ (range of -4.0 to $+0.6 \%$ ) is very close to the realised growth rate of $-2.1 \%$, and the projected growth for the rest of the world of $+1.0 \%$ (range of -0.4 to $2.5 \%$ ) matches the realised rate of $1.3 \%$.

In 2016, the largest absolute contributions to global $\mathrm{CO}_{2}$ emissions were from China (28\%), the USA $(15 \%)$, the EU (28 member states; $10 \%)$, and India $(6.7 \%)$. The percentages are the fraction of the global emissions including bunker fuels $(3.1 \%)$. These four regions account for $59 \%$ of global $\mathrm{CO}_{2}$ emissions. Growth rates for these countries from 2015 to 2016 were $-0.3 \%$ (China), $-2.1 \%$ (USA), $-0.3 \%$ (EU28), and $+4.5 \%$ (India). The per-capita $\mathrm{CO}_{2}$ emissions in 2016 were $1.1 \mathrm{tC}$ person ${ }^{-1} \mathrm{yr}^{-1}$ for the globe and were 4.5 (USA), 2.0 (China), 1.9 (EU28), and 0.5 (India) $\mathrm{tC}_{\mathrm{C}}$ person ${ }^{-1} \mathrm{yr}^{-1}$ for the four highest emitting countries (Fig. 5e).

Territorial emissions in Annex B countries (developed countries as per the Kyoto Protocol which initially had binding mitigation targets) decreased by $-0.2 \% \mathrm{yr}^{-1}$ on average during 1990-2015. Trends observed for consumption emissions were less monotonic, with $0.7 \% \mathrm{yr}^{-1}$ growth over 1990-2007 and a $-1.2 \% \mathrm{yr}^{-1}$ decrease over 2007-2015 (Fig. 5c). In non-Annex B countries (emerging economies and less developed countries as per the Kyoto Protocol with no binding mitigation commitments) territorial emissions grew at $4.6 \% \mathrm{yr}^{-1}$ during 1990-2015, while consumption emissions grew at $4.5 \% \mathrm{yr}^{-1}$. In $1990,65 \%$ of global territorial emissions were emitted in Annex B countries (32\% in non-Annex B and $2 \%$ in bunker fuels used for international shipping and aviation), while in 2015 this had reduced to $37 \%$ (60\% in non-Annex B and $3 \%$ in bunker fuels). For consumption emissions, this split was $68 \%$ in 1990 and $42 \%$ 
in 2015 ( 32 to $58 \%$ in non-Annex B). The difference between territorial and consumption emissions (the net emission transfer via international trade) from non-Annex B to Annex B countries has increased from near zero in 1990 to $0.3 \mathrm{GtC} \mathrm{yr}^{-1}$ around 2005 and remained relatively stable afterwards until the last year available (2015; Fig. 5). The increase in net emission transfers of $0.28 \mathrm{GtC} \mathrm{yr}^{-1}$ between 1990 and 2015 compares with the emission reduction of $0.5 \mathrm{GtC} \mathrm{yr}^{-1}$ in Annex B countries. These results show the importance of net emission transfer via international trade from non-Annex B to Annex B countries, as well as the stabilisation of emissions transfer when averaged over Annex B countries during the past decade. In 2015, the biggest emitters from a consumption perspective were China ( $23 \%$ of the global total), USA (16\%), EU28 (12\%), and India (6\%).

The global $\mathrm{CO}_{2}$ emissions from land-use change are estimated as $1.3 \pm 0.5 \mathrm{GtC}$ in 2016 , as for the previous decade but with low confidence in the annual change.

\subsubsection{Partitioning among the atmosphere, ocean, and land}

The growth rate in atmospheric $\mathrm{CO}_{2}$ concentration was $6.0 \pm 0.2 \mathrm{GtC}$ in $2016(2.85 \pm 0.09 \mathrm{ppm}$; Fig. 4; Dlugokencky and Tans, 2018). This is well above the 2007-2016 average of $4.7 \pm 0.1 \mathrm{GtC} \mathrm{yr}^{-1}$ and reflects the large interannual variability in the growth rate of atmospheric $\mathrm{CO}_{2}$ concentration associated with El Niño and La Niña events.

The estimated ocean $\mathrm{CO}_{2}$ sink was $2.6 \pm 0.5 \mathrm{GtC} \mathrm{yr}^{-1}$ in 2016, only marginally above 2015 according to the average of the ocean models but with large differences among estimates (Fig. 7).

The terrestrial $\mathrm{CO}_{2}$ sink from the model ensemble was $2.7 \pm 1.0 \mathrm{GtC}$ in 2016, near the decadal average (Fig. 4) and consistent with constraints from the rest of the budget (Table 5).

The budget imbalance was $-0.2 \mathrm{GtC}$ in 2016 , indicating a small overestimation of the emissions and/or underestimation of the sink for that year, with large uncertainties.

\subsection{Global carbon budget projection for year 2017}

\subsection{1 $\mathrm{CO}_{2}$ emissions}

Emissions from fossil fuels and industry $\left(E_{\mathrm{FF}}\right)$ for 2017 are projected to increase by $+2.0 \%$ (range of 0.8 to $+3.0 \%$; Table 7; Jackson et al., 2017; Peters et al., 2017). Our method contains several assumptions that could influence the estimate beyond the given range, and as such, it has an indicative value only. Within the given assumptions, global emissions would increase to $10.0 \pm 0.5 \mathrm{GtC}\left(36.8 \pm 1.8 \mathrm{GtCO}_{2}\right)$ in 2017. (At the time of going to press, the growth in $E_{\mathrm{FF}}$ for 2017 had been revised to $1.5 \%$ (range of 0.7 to $2.4 \%$ ). A detailed update will be provided in the Global Carbon Budget 2018.)
For China, the expected change based on available data as of 19 September 2017 (see Sect. 2.1.4) is for an increase in emissions of $+3.5 \%$ (range of +0.7 to $+5.4 \%$ ) in 2017 compared to 2016. This is based on estimated growth in coal $(+3 \%$; the main fuel source in China), oil $(+5.0 \%)$, and natural gas $(+11.7 \%)$ consumption and a decline in cement production $(-0.5 \%)$. The uncertainty range considers the spread between different data sources and variances of typical revisions of Chinese data over time. The uncertainty in the growth rate of coal consumption also reflects uncertainty in the evolution of energy density and carbon content of coal.

For the USA, the EIA emissions projection for 2017 combined with cement data from USGS gives a decrease of $-0.4 \%$ (range of -2.7 to $+1.9 \%$ ) compared to 2016 .

For India, our projection for 2017 gives an increase of $+2.0 \%$ (range of 0.2 to $+3.8 \%$ ) over 2016 .

For the rest of the world (including EU28), the expected growth for 2017 is $+1.6 \%$ (range of 0.0 to $+3.2 \%$ ). This is computed using the GDP projection for the world excluding China, USA, and India of $2.4 \%$ made by the IMF (IMF, 2017) and a decrease in $I_{\mathrm{FF}}$ of $-1.1 \% \mathrm{yr}^{-1}$ which is the average from 2007 to 2016 . The uncertainty range is based on the standard deviation of the interannual variability in $I_{\mathrm{FF}}$ during 2007-2016 of $\pm 1.0 \% \mathrm{yr}^{-1}$ and our estimate of uncertainty in the IMF's GDP forecast of $\pm 0.5 \%$. Applying the method to the EU28 individually would give a projection of $-0.2 \%$ (range of -2.0 to $+1.6 \%$ ) for EU28 and $+2.3 \%$ (range of +0.5 to $+4.0 \%$ ) for the remaining countries, though the uncertainties grow with the level of disaggregation.

Emissions from land-use change $\left(E_{\mathrm{LUC}}\right)$ for 2017 are projected to remain in line with or slightly lower than their 2016 level of $1.3 \mathrm{GtC}$, based on active fire detections by October.

\subsubsection{Partitioning among the atmosphere, ocean, and land}

The 2017 growth in atmospheric $\mathrm{CO}_{2}$ concentration $\left(G_{\mathrm{ATM}}\right)$ is projected to be $5.3 \mathrm{GtC}$ with uncertainty around $\pm 1 \mathrm{GtC}$ $(2.5 \pm 0.5 \mathrm{ppm})$. Combining projected $E_{\mathrm{FF}}, E_{\mathrm{LUC}}$, and $G_{\mathrm{ATM}}$ suggests a combined land and ocean sink $\left(S_{\text {LAND }}+S_{\text {OCEAN }}\right)$ of about $6 \mathrm{GtC}$ for 2017. Although each term has large uncertainty, the oceanic sink $S_{\text {OCEAN }}$ has generally low interannual variability and is likely to remain close to its 2016 value of around $2.6 \mathrm{GtC}$, leaving a rough estimated land sink $S_{\text {LAND }}$ of around $3.4 \mathrm{GtC}$, near its decadal average (Table 5). This behaviour of the sink is expected due to the El Niño neutral conditions that prevailed during 2017 , in stark contrast to the strong El Niño conditions in 2015 and 2016 that reduced the land sink. (At the time of going to press, the $G_{\text {ATM }}$ for 2017 number had been revised to $2.38 \pm 0.1 \mathrm{ppm}$ with preliminary data to the end of 2017.) 
Table 7. Comparison of the projection with realised emissions from fossil fuels and industry $\left(E_{\mathrm{FF}}\right)$. The "Actual" values are first estimate available using actual data, and the "Projected" values refer to the estimate made before the end of the year for each publication. Projections based on a different method from that described here during 2008-2014 are available in Le Quéré et al. (2016). All values are adjusted for leap years.

\begin{tabular}{|c|c|c|c|c|c|c|c|c|c|c|}
\hline & \multicolumn{2}{|c|}{ World } & \multicolumn{2}{|l|}{ China } & \multicolumn{2}{|l|}{ USA } & \multicolumn{2}{|l|}{ India } & \multicolumn{2}{|c|}{ Rest of world } \\
\hline & Projected & Actual & Projected & Actual & Projected & Actual & Projected & Actual & Projected & Actual \\
\hline $2015^{\mathrm{a}}$ & $\begin{array}{l}-0.6 \% \\
(-1.6 \text { to } 0.5)\end{array}$ & $0.06 \%$ & $\begin{array}{l}-3.9 \% \\
(-4.6 \text { to }-1.1)\end{array}$ & $-0.7 \%$ & $\begin{array}{l}-1.5 \% \\
(-5.5 \text { to } 0.3)\end{array}$ & $-2.5 \%$ & - & - & $\begin{array}{l}1.2 \% \\
(-0.2 \text { to } 2.6)\end{array}$ & $1.2 \%$ \\
\hline $2016^{\mathrm{b}}$ & $\begin{array}{l}-0.2 \% \\
(-1.0 \text { to }+1.8)\end{array}$ & $+0.18 \%$ & $\begin{array}{l}-0.5 \% \\
(-3.8 \text { to }+1.3)\end{array}$ & $-0.3 \%$ & $\begin{array}{l}-1.7 \% \\
(-4.0 \text { to }+0.6)\end{array}$ & $-2.1 \%$ & - & - & $\begin{array}{l}+1.0 \% \\
(-0.4 \text { to }+2.5)\end{array}$ & $1.3 \%$ \\
\hline
\end{tabular}

a Jackson et al. (2016) and Le Quéré et al. (2015a). ${ }^{\text {b }}$ Le Quéré et al. (2016). ${ }^{\mathrm{c}}$ This study.

Table 8. Cumulative $\mathrm{CO}_{2}$ for different time periods in gigatonnes of carbon $(\mathrm{GtC})$. All uncertainties are reported as $\pm 1 \sigma . E_{\mathrm{LUC}}$ and $S_{\mathrm{OCEAN}}$ have been revised to incorporate multiple estimates (Sect. 3.5), and, unlike previous versions of the global carbon budget, the terrestrial sink $\left(S_{\text {LAND }}\right)$ is now estimated independently from the mean of the DGVM. Therefore, the table also shows the budget imbalance, which provides a measure of the discrepancies among the nearly independent estimates. Its uncertainty exceeds $\pm 60 \mathrm{GtC}$. The method used here does not capture the loss of additional sink capacity from reduced forest cover, which is about $15 \mathrm{GtC}$ and would exacerbate the budget imbalance (see Sect. 2.7.3). All values are rounded to the nearest $5 \mathrm{GtC}$ and therefore columns do not necessarily add to zero.

\begin{tabular}{|c|c|c|c|c|c|}
\hline Units of GtC & 1750-2016 & $1850-2005$ & 1959-2016 & 1870-2016 & $1870-2017^{\mathrm{a}}$ \\
\hline \multicolumn{6}{|l|}{ Emissions } \\
\hline Fossil fuels and industry $\left(E_{\mathrm{FF}}\right)$ & $420 \pm 20$ & $320 \pm 15$ & $345 \pm 15$ & $420 \pm 20$ & $430 \pm 20$ \\
\hline Land-use change emissions ( $\left.E_{\text {LUC }}\right)$ & $225 \pm 75$ & $180 \pm 60$ & $75 \pm 40$ & $180 \pm 60$ & $180 \pm 60$ \\
\hline Total emissions & $645 \pm 80$ & $500 \pm 60$ & $415 \pm 45$ & $600 \pm 65$ & $610 \pm 65$ \\
\hline \multicolumn{6}{|l|}{ Partitioning } \\
\hline $\begin{array}{l}\text { Growth rate in atmospheric } \mathrm{CO}_{2} \\
\text { concentration }\left(G_{\mathrm{ATM}}\right)^{\mathrm{b}}\end{array}$ & $270 \pm 5$ & $200 \pm 5$ & $185 \pm 5$ & $245 \pm 5$ & $250 \pm 5$ \\
\hline Ocean sink $\left(S_{\text {OCEAN }}\right)$ & $160 \pm 20$ & $145 \pm 20$ & $95 \pm 20$ & $145 \pm 20$ & $150 \pm 20$ \\
\hline Terrestrial sink $\left(S_{\mathrm{LAND}}\right)^{\mathrm{c}}$ & $205 \pm 55$ & $155 \pm 45$ & $135 \pm 35$ & $190 \pm 55$ & $190 \pm 55$ \\
\hline \multicolumn{6}{|l|}{ Budget imbalance } \\
\hline $\begin{array}{l}B_{\mathrm{IM}}=E_{\mathrm{FF}}+E_{\mathrm{LUC}}-\left(G_{\mathrm{ATM}}+\right. \\
\left.S_{\mathrm{OCEAN}}+S_{\mathrm{LAND}}\right)\end{array}$ & (15) & (0) & (0) & (20) & (20) \\
\hline
\end{tabular}

a Using projections for year 2017 (Sect. 3.3).

${ }^{\mathrm{b}}$ A small change was introduced from Le Quére et al. (2016) to be consistent with the annual analysis, whereby the growth in atmospheric $\mathrm{CO}_{2}$ concentration is calculated from the difference between concentrations at the end of the year (deseasonalised), rather than averaged over the year

${ }^{c}$ Assuming $S_{\text {LAND }}$ increases proportionally to $G_{\text {ATM }}$ prior to 1860 when the DGVM estimates start.

\subsection{Cumulative sources and sinks}

Cumulative historical sources and sinks have been revised compared to the previous global carbon budgets. This version of the global carbon budget uses two updated bookkeeping models instead of one bookkeeping model only, uses two ocean sink data products instead of one data product only, and uses multiple DGVMs for the land sink instead of deriving the land sink from the residual of the other terms. As a result of these methodological changes, the cumulative emissions and their partitioning are significantly larger (by about $50 \mathrm{GtC}$ ) than our previous estimates. This large difference highlights the uncertainty in reconstructing historical emission sources and sinks, and this is noted through the large uncertainty associated with each term.

Cumulative fossil fuel and industry emissions for 1870 2016 were $420 \pm 20 \mathrm{GtC}$ for $E_{\mathrm{FF}}$ and, with the revised bookkeeping models, $180 \pm 60 \mathrm{GtC}$ for $E_{\mathrm{LUC}}$ (Table 8), for a total of $600 \pm 65 \mathrm{GtC}$. The cumulative emissions from $E_{\mathrm{LUC}}$ are particularly uncertain, with a large spread among individual estimates of $135 \mathrm{GtC}$ (Houghton) and $225 \mathrm{GtC}$ (BLUE) for the two bookkeeping models and a range of 70 to $230 \mathrm{GtC}$ for the 12 DGVMs. These estimates are consistent with indi- 
rect constraints from biomass observations (Li et al., 2017), but given the large spread a best estimate is difficult to ascertain.

With the revised methodology, emissions were partitioned among the atmosphere $(245 \pm 5 \mathrm{GtC})$, ocean $(145 \pm 20 \mathrm{GtC})$, and the land $(190 \pm 55 \mathrm{GtC})$. The use of nearly independent estimates for the individual terms shows a cumulative budget imbalance of $20 \mathrm{GtC}$ during 1870-2016, which, if correct, suggests emissions are too high by the same proportion or the land or ocean sinks are underestimated. The imbalance originates largely from the large $E_{\mathrm{LUC}}$ during the mid1920s and the mid-1960s which is unmatched by a growth in atmospheric $\mathrm{CO}_{2}$ concentration as recorded in ice cores (Fig. 3). The known loss of additional sink capacity of about $15 \mathrm{GtC}$ due to reduced forest cover has not been accounted for in our method and further exacerbates the budget imbalance (Sect. 2.7.3).

Cumulative emissions through to year 2017 increase to $610 \pm 65 \mathrm{GtC}\left(2235 \pm 240 \mathrm{GtCO}_{2}\right)$, with about $70 \%$ contribution from $E_{\mathrm{FF}}$ and about $30 \%$ contribution from $E_{\mathrm{LUC}}$. Cumulative emissions and their partitioning for different periods are provided in Table 8 .

Given the large revision in cumulative emissions, and its persistent uncertainties, we suggest extreme caution is needed if using cumulative emission estimate to determine the remaining carbon budget to stay below the given temperature limit (Rogelj et al., 2016). We suggest estimating the remaining carbon budget by integrating scenario data from the current time to some time in the future as proposed recently (Millar et al., 2017).

\section{Discussion}

Each year when the global carbon budget is published, each component for all previous years is updated to take into account corrections that are the result of further scrutiny and verification of the underlying data in the primary input data sets. The updates have generally been relatively small (Fig. 9). However, this year, we introduced a major methodological change to assess both $S_{\text {OCEAN }}$ and $S_{\text {LAND }}$ directly using multiple process models constrained by observations and to keep track of the budget imbalance separately. We also use multiple bookkeeping estimates for $E_{\mathrm{LUC}}$. Therefore, the update compared to previous years has led to more substantial revisions, particularly concerning the mean $S_{\text {OCEAN }}$, the variability of $S_{\mathrm{LAND}}$, and the trends in $E_{\mathrm{LUC}}$ (Fig. 9).

The budget imbalance provides a measure of the limitations in observations, in understanding or full representation of processes in models, and/or in the integration of the carbon budget components. The mismatch between the total emissions (red line in Fig. 3) and the total sinks (including the atmosphere) illustrates the need to explicitly identify imbalances separately rather than assigning residuals to the land sink as was done in the past. The mean global budget imbal- ance is close to zero and there is no trend over the entire time period (Fig. 4). However, the budget imbalance reaches as much as $\pm 2 \mathrm{GtC} \mathrm{yr}^{-1}$ in individual years and $\pm 0.6 \mathrm{GtC} \mathrm{yr}^{-1}$ in individual decades (Table 6). Such large budget imbalance limits our ability to verify reported emissions and limits our confidence in the underlying processes regulating the carbon cycle feedbacks with climate change (Peters et al., 2017).

Another semi-independent way to evaluate the carbon budget results is provided through the use of atmospheric and oceanic $\mathrm{CO}_{2}$ data in data products (atmospheric inversions and $p \mathrm{CO}_{2}$-based ocean flux products). The comparison shows a first-order consistency between $p \mathrm{CO}_{2}$-based data products and process models but with substantial discrepancies, particularly for the allocation of the mean surface fluxes between the tropics and the Northern Hemisphere and for highlighting underestimated decadal variability in $S_{\text {OCEAN }}$. Understanding the causes of these discrepancies and further analysis of regional carbon budgets would provide additional information to quantify and improve our estimates, as has been shown by the project REgional Carbon Cycle Assessment and Processes (RECCAP; Canadell et al., 2012).

To help improve the global carbon budget components, we provide a list of the major known uncertainties for each component, defined as those uncertainties that have been a demonstrated effect of at least $0.3 \mathrm{GtC} \mathrm{yr}^{-1}$ (Table 9). We identified multiple sources of uncertainties for $E_{\mathrm{LUC}}$, including in the land-cover and land-use change statistics, representation of management processes, and methodologies (e.g. Arneth et al., 2017). There are also multiple sources of uncertainties in $S_{\text {LAND }}$ and $S_{\text {OCEAN. }}$. When assessing $S_{\text {LAND }}$ using DGVMs, uncertainties mostly related to the understanding and representation of processes as evidenced by the large model spread presented here. Similarly, when assessing $S_{\text {OCEAN }}$ with GOBMs, multiple studies based on observations have shown variability in the ocean $\mathrm{CO}_{2}$ sink larger than estimated by the models presented here, particularly related to representing the effects of variable ocean circulation in models (e.g. DeVries et al., 2017; Landschützer et al., 2015; Keeling and Manning, 2014). Finally, the quality of the energy statistics and of the emissions factors is the largest source of uncertainties for $E_{\mathrm{FF}}$. There are no demonstrated uncertainties in $G_{\text {ATM }}$ larger than $0.3 \mathrm{GtC} \mathrm{yr}^{-1}$, although the conversion of the growth rate into a global annual flux assuming instantaneous mixing throughout the atmosphere introduces additional errors that have not yet been quantified. Multiple other sources of uncertainties have been identified (i.e. in cement emissions) that could add up to significant contributions but are unlikely to be the main sources of the budget imbalance.

Although multiple processes have been identified here, some will increase variability (e.g. land management processes, ocean circulation) while others might decrease it (e.g. better energy statistics, response to rainfall variability), and processes would not be all acting simultaneously. It is also possible that further yet unknown processes are not taken 

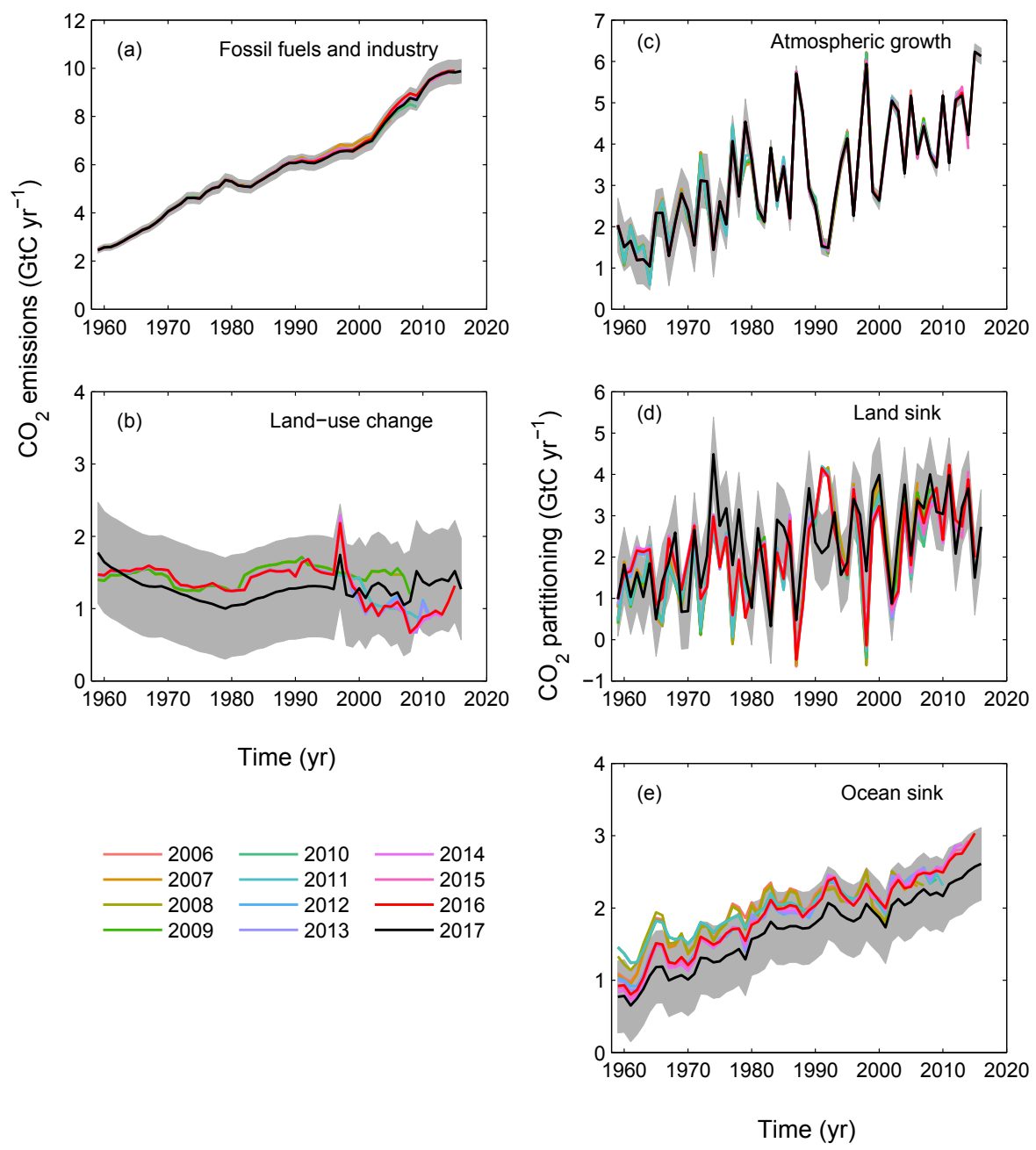

Figure 9. Comparison of global carbon budget components released annually by GCP since 2006. $\mathrm{CO}_{2}$ emissions from (a) fossil fuels and industry $\left(E_{\mathrm{FF}}\right)$ and $(\mathbf{b})$ land-use change $\left(E_{\mathrm{LUC}}\right)$, as well as their partitioning among (c) the atmosphere $\left(G_{\mathrm{ATM}}\right)$, (d) the land $\left(S_{\mathrm{LAND}}\right)$, and (e) the ocean $\left(S_{\text {OCEAN }}\right)$. See legend for the corresponding years, and Table 3 for references. The budget year corresponds to the year when the budget was first released. All values are in $\mathrm{GtC} \mathrm{yr}^{-1}$. Grey shading shows the uncertainty bounds representing $\pm 1 \sigma$ of the current global carbon budget.

into account. Better understanding the source of the carbon imbalance and how to resolve it is critical to progress further in the understanding of the contemporary carbon budget.

Although we have presented six components of the global carbon budget individually, different aggregations of terms are possible. In particular $S_{\mathrm{LAND}}, E_{\mathrm{LUC}}$, and $B_{\mathrm{IM}}$ could be aggregated into land fluxes and total uncertainty, as traditionally done, which would result in generally lower uncertainty compared to each term individually (see Table 5). This information is limited in usefulness, however, as it mixes direct and indirect processes and bring in errors from other components and hence the signal becomes difficult to interpret. However, providing a realistic assessment of uncertainties for $S_{\mathrm{LAND}}$ and $E_{\mathrm{LUC}}$ is also difficult. Here we have used the model spread as a measure of uncertainty, which may be, on the one hand, underestimated because it includes only partly uncertainty in the underlying observations and, on the other hand, overestimated as it includes artificial spread from different boundary limits among models. Therefore, further work is needed not only to better quantify the fluxes but also to better describe and quantify the uncertainty and reduce them where possible.

There are many more uncertainties affecting the annual estimates compared to the mean and trend, some of which could be improved with better data. Of the various terms in the global budget, only the emissions from fossil fuels and industry and the growth rate in atmospheric $\mathrm{CO}_{2}$ concentration are based primarily on empirical inputs supporting annual estimates in this carbon budget. $p \mathrm{CO}_{2}$-based flux products for the ocean $\mathrm{CO}_{2}$ sink and atmospheric inversions based on ob- 
Table 9. Major known sources of uncertainties in each component of the global carbon budget, defined as input data or processes that have

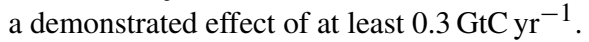

\begin{tabular}{|c|c|c|c|c|}
\hline Source of uncertainty & Timescale (years) & Location & Status & Evidence \\
\hline \multicolumn{5}{|c|}{ Emissions from fossil fuels and industry ( $E_{\mathrm{FF}} ;$ Sect. 2.1) } \\
\hline energy statistics & annual to decadal & mainly China & see Sect. 2.1 & Korsbakken et al. (2016) \\
\hline carbon content of coal & decadal & mainly China & see Sect. 2.1 & Liu et al. (2015) \\
\hline \multicolumn{5}{|c|}{ Emissions from land-use change ( $E_{\mathrm{LUC}} ;$ Sect. 2.2) } \\
\hline $\begin{array}{l}\text { land-cover and land-use } \\
\text { change statistics }\end{array}$ & continuous & $\begin{array}{l}\text { global, in particular } \\
\text { tropics }\end{array}$ & see Sect. 2.2 & Houghton et al. (2012) \\
\hline sub-grid-scale transitions & annual to decadal & global & see Table 4 & Wilkenskjeld et al. (2014) \\
\hline vegetation biomass & annual to decadal & $\begin{array}{l}\text { global, in particular } \\
\text { tropics }\end{array}$ & see Table 4 & Houghton et al. (2012) \\
\hline wood and crop harvest & annual to decadal & global; SE Asia & see Table 4 & Arneth et al. (2017) \\
\hline peat burning ${ }^{\mathrm{a}}$ & multi-decadal trend & global & see Table 4 & van der Werf et al. (2010) \\
\hline $\begin{array}{l}\text { loss of additional sink } \\
\text { capacity }\end{array}$ & multi-decadal trend & global & $\begin{array}{l}\text { not included; } \\
\text { Sect. 2.7.3 }\end{array}$ & Gitz and Ciais (2003) \\
\hline \multicolumn{5}{|c|}{ Atmospheric growth rate $\left(G_{\mathrm{ATM}}\right) \rightarrow$ no demonstrated uncertainties larger than $\pm 0.3 \mathrm{GtC}_{\mathrm{yr}}{ }^{-1, \mathrm{~b}}$} \\
\hline \multicolumn{5}{|l|}{ Ocean sink $\left(S_{\text {OCEAN }}\right)$} \\
\hline $\begin{array}{l}\text { variability in oceanic } \\
\text { circulation }^{c}\end{array}$ & $\begin{array}{l}\text { semi-decadal to } \\
\text { decadal }\end{array}$ & $\begin{array}{l}\text { global, in particular } \\
\text { Southern Ocean }\end{array}$ & see Sect. 2.4 .2 & DeVries et al. (2017) \\
\hline $\begin{array}{l}\text { anthropogenic changes in } \\
\text { nutrient supply }\end{array}$ & multi-decadal trend & global & not included & Duce et al. (2008) \\
\hline \multicolumn{5}{|l|}{ Land sink $\left(S_{\text {LAND }}\right)$} \\
\hline $\begin{array}{l}\text { strength of } \mathrm{CO}_{2} \\
\text { fertilisation }\end{array}$ & multi-decadal trend & global & see Sect. 2.5 & Wenzel et al. (2016) \\
\hline $\begin{array}{l}\text { response to variability in } \\
\text { temperature and rainfall }\end{array}$ & annual to decadal & $\begin{array}{l}\text { global, in particular } \\
\text { tropics }\end{array}$ & see Sect. 2.5 & Cox et al. (2013) \\
\hline $\begin{array}{l}\text { nutrient limitation and } \\
\text { supply }\end{array}$ & multi-decadal trend & global & see Sect. 2.5 & Zaehle et al. (2011) \\
\hline $\begin{array}{l}\text { response to diffuse } \\
\text { radiation }\end{array}$ & annual & global & see Sect. 2.5 & Mercado et al. (2009) \\
\hline
\end{tabular}

a As result of interactions between land use and climate.

b The uncertainties in $G_{\mathrm{ATM}}$ have been estimated as $\pm 0.2 \mathrm{GtC} \mathrm{yr}^{-1}$, although the conversion of the growth rate into a global annual flux assuming instantaneous mixing throughout the atmosphere introduces additional errors that have not yet been quantified.

c Could in part be due to uncertainties in atmospheric forcing (Swart et al., 2014).

served atmospheric $\mathrm{CO}_{2}$ concentrations provide new ways to evaluate the model results, but there are still large discrepancies among estimates. Given the growing reliance on process models and $p \mathrm{CO}_{2}$-based flux products in our global carbon budget, it is critical that data-based metrics are developed and used to inform the selection of models and the improvement of their process representation in the long term.

\section{Data availability}

The data presented here are made available in the belief that their wide dissemination will lead to greater understanding and new scientific insights of how the carbon cycle works, how humans are altering it, and how we can mitigate the resulting human-driven climate change. The free availability of these data does not constitute permission for publication of the data. For research projects, if the data are essential to the work, or if an important result or conclusion depends on the data, co-authorship may need to be considered. Full contact details and information on how to cite the data included in the GCP (2017) release are given at the top of each page in the accompanying database and summarised in Table 2.

The accompanying database includes two Excel files organised in the following spreadsheets (accessible with the free viewer at http://www.microsoft.com/en-us/download/ details.aspx?id=10).

File Global_Carbon_Budget_2017v1.0.xlsx includes the following:

\section{Summary}


2. The global carbon budget (1959-2016)

3. Global $\mathrm{CO}_{2}$ emissions from fossil fuels and cement production by fuel type, and the per-capita emissions (1959-2016)

4. $\mathrm{CO}_{2}$ emissions from land-use change from the individual methods and models (1959-2016)

5. Ocean $\mathrm{CO}_{2}$ sink from the individual ocean models and $p \mathrm{CO}_{2}$-based products (1959-2016)

6. Terrestrial $\mathrm{CO}_{2}$ sink from the DGVMs (1959-2016)

7. Additional information on the carbon balance prior to 1959 (1750-2016)

File National_Carbon_Emissions_2017v1.0.xlsx includes the following:

1. Summary

2. Territorial country $\mathrm{CO}_{2}$ emissions from fossil fuels and industry (1959-2016) from CDIAC, extended to 2016 using BP data

3. Territorial country $\mathrm{CO}_{2}$ emissions from fossil fuels and industry (1959-2016) from CDIAC with UNFCCC data overwritten where available, extended to 2016 using BP data

4. Consumption country $\mathrm{CO}_{2}$ emissions from fossil fuels and industry and emissions transfer from the international trade of goods and services (1990-2015) using CDIAC/UNFCCC data (worksheet 3 above) as reference

5. Emissions transfers (consumption minus territorial emissions; 1990-2015)

6. Country definitions

7. Details of disaggregated countries

8. Details of aggregated countries

National emissions data are also available from the Global Carbon Atlas (http://globalcarbonatlas.org).

\section{Conclusions}

The estimation of global $\mathrm{CO}_{2}$ emissions and sinks is a major effort by the carbon cycle research community that requires a combination of measurements and compilation of statistical estimates and results from models. The delivery of an annual carbon budget serves two purposes. First, there is a large demand for up-to-date information on the state of the anthropogenic perturbation of the climate system and its underpinning causes. A broad stakeholder community relies on the data sets associated with the annual carbon budget including scientists, policy makers, businesses, journalists, and the broader society increasingly engaged in adapting to and mitigating human-driven climate change. Second, over the last decade we have seen unprecedented changes in the human and biophysical environments (e.g. changes in the growth of fossil fuel emissions, ocean temperatures, and strength of the sink), which call for frequent assessments of the state of the planet and, by implication, a better understanding of the future evolution of the carbon cycle. Both the ocean and the land surface presently remove a large fraction of anthropogenic emissions. Any significant change in the function of carbon sinks is of great importance to climate policymaking, as they affect the excess $\mathrm{CO}_{2}$ remaining in the atmosphere and therefore the compatible emissions for any climate stabilisation target. Better constraints of carbon cycle models against contemporary data sets raise the capacity for the models to become more accurate at future projections. This all requires more frequent, robust, and transparent data sets and methods that can be scrutinised and replicated. This paper via "living data" will help to keep track of new budget updates. 


\section{Appendix A}

Table A1. Comparison of the processes included $(\mathrm{Y})$ or not $(\mathrm{N})$ in the bookkeeping and dynamic global vegetation models for their estimates

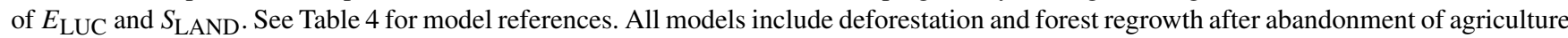
(or from afforestation activities on agricultural land).

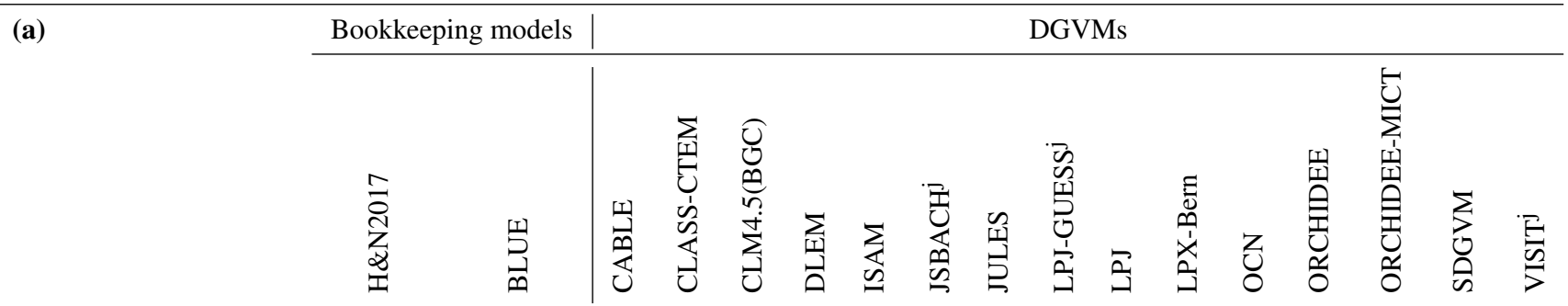

\begin{tabular}{|c|c|c|c|c|c|c|c|c|c|c|c|c|c|c|c|c|c|}
\hline \multicolumn{18}{|c|}{ Processes relevant for $E_{\mathrm{LUC}}$} \\
\hline $\begin{array}{l}\text { Wood harvest and forest } \\
\text { degradation }^{\text {a }}\end{array}$ & $\mathrm{Y}$ & $\mathrm{Y}$ & $\mathrm{Y}$ & $\mathrm{N}$ & $\mathrm{Y}$ & $\mathrm{Y}$ & $\mathrm{Y}$ & & $\mathrm{N}$ & & $\mathrm{N}$ & $\mathrm{N}^{\mathrm{d}}$ & $\mathrm{Y}$ & $\mathrm{Y}$ & $\mathrm{N}$ & $\mathrm{N}$ & \\
\hline $\begin{array}{l}\text { Shifting cultivation/ } \\
\text { subgrid scale transitions }\end{array}$ & $\mathrm{N}^{\mathrm{b}}$ & $\mathrm{Y}$ & $\mathrm{Y}$ & $\mathrm{N}$ & $\mathrm{Y}$ & $\mathrm{N}$ & $\mathrm{N}$ & & $\mathrm{N}$ & & $\mathrm{N}$ & $N^{d}$ & $\mathrm{~N}$ & $\mathrm{~N}$ & $\mathrm{~N}$ & $\mathrm{~N}$ & \\
\hline Cropland harvest & $Y^{i}$ & $Y^{i}$ & $\mathrm{~N}$ & $\mathrm{~L}$ & $\mathrm{~N}$ & $\mathrm{Y}$ & $\mathrm{Y}$ & & $\mathrm{N}$ & & Y & $\mathrm{Y}$ & $\mathrm{Y}$ & $\mathrm{Y}$ & $\mathrm{Y}$ & $\mathrm{Y}$ & \\
\hline Peat fires & $\mathrm{Y}$ & $\mathrm{Y}$ & $\mathrm{N}$ & $\mathrm{N}$ & $\mathrm{Y}$ & $\mathrm{N}$ & $\mathrm{N}$ & & $\mathrm{N}$ & & $\mathrm{N}$ & $\mathrm{N}$ & $\mathrm{N}$ & $\mathrm{N}$ & $\mathrm{N}$ & $\mathrm{N}$ & \\
\hline $\begin{array}{l}\text { Fire as a management } \\
\text { tool }\end{array}$ & $\mathrm{Y}^{\mathrm{i}}$ & $\mathrm{Y}^{\mathrm{i}}$ & $\mathrm{N}$ & $\mathrm{N}$ & $\mathrm{N}$ & $\mathrm{N}$ & $\mathrm{N}$ & & $\mathrm{N}$ & & $\mathrm{N}$ & $\mathrm{N}$ & $\mathrm{N}$ & $\mathrm{N}$ & $\mathrm{N}$ & $\mathrm{N}$ & \\
\hline $\mathrm{N}$ fertilisation & $Y^{i}$ & $Y^{i}$ & $\mathrm{~N}$ & $\mathrm{~N}$ & $\mathrm{~N}$ & $\mathrm{Y}$ & $\mathrm{Y}$ & & $\mathrm{N}$ & & $\mathrm{N}$ & Y & $\mathrm{Y}$ & $\mathrm{N}$ & $\mathrm{N}$ & $\mathrm{N}$ & \\
\hline Tillage & $Y^{i}$ & $\mathrm{Y}^{\mathrm{i}}$ & $\mathrm{N}$ & $Y^{f}$ & $\mathrm{~N}$ & $\mathrm{~N}$ & $\mathrm{~N}$ & & $\mathrm{~N}$ & & $\mathrm{~N}$ & $\mathrm{~N}$ & $\mathrm{~N}$ & $\mathrm{Y}^{\mathrm{h}}$ & $\mathrm{Y}^{\mathrm{h}}$ & $\mathrm{N}$ & \\
\hline Irrigation & $\mathrm{Y}^{\mathrm{i}}$ & $\mathrm{Y}^{\mathrm{i}}$ & $\mathrm{N}$ & $\mathrm{N}$ & $\mathrm{N}$ & $\mathrm{Y}$ & $\mathrm{Y}$ & & $\mathrm{N}$ & & $\mathrm{N}$ & $\mathrm{N}$ & $\mathrm{N}$ & $\mathrm{N}$ & $\mathrm{N}$ & $\mathrm{N}$ & \\
\hline Wetland drainage & $Y^{i}$ & $\mathrm{Y}^{\mathrm{i}}$ & $\mathrm{N}$ & $\mathrm{N}$ & $\mathrm{N}$ & $\mathrm{N}$ & $\mathrm{N}$ & & $\mathrm{N}$ & & $\mathrm{N}$ & $\mathrm{N}$ & $\mathrm{N}$ & $\mathrm{N}$ & $\mathrm{N}$ & $\mathrm{N}$ & \\
\hline Erosion & $Y^{i}$ & $Y^{i}$ & $\mathrm{~N}$ & $\mathrm{~N}$ & $\mathrm{~N}$ & $\mathrm{~N}$ & $\mathrm{~N}$ & & $\mathrm{~N}$ & & $\mathrm{~N}$ & $\mathrm{~N}$ & $\mathrm{~N}$ & $\mathrm{~N}$ & $\mathrm{~N}$ & $\mathrm{~N}$ & \\
\hline $\begin{array}{l}\text { Southeast Asia peat } \\
\text { drainage }\end{array}$ & $\mathrm{Y}$ & $\mathrm{Y}$ & $\mathrm{N}$ & $\mathrm{N}$ & $\mathrm{N}$ & $\mathrm{N}$ & $\mathrm{N}$ & & $\mathrm{N}$ & & $\mathrm{N}$ & $\mathrm{N}$ & $\mathrm{N}$ & $\mathrm{N}$ & $\mathrm{N}$ & $\mathrm{N}$ & \\
\hline $\begin{array}{l}\text { Grazing and mowing } \\
\text { harvest }\end{array}$ & $\mathrm{Y}^{\mathrm{i}}$ & $\mathrm{Y}^{\mathrm{i}}$ & $\mathrm{N}$ & $\mathrm{N}$ & $\mathrm{N}$ & $\mathrm{N}$ & $\mathrm{Y}$ & & $\mathrm{N}$ & & $\mathrm{Y}$ & $\mathrm{N}$ & $\mathrm{N}$ & $\mathrm{N}$ & $\mathrm{N}$ & $\mathrm{N}$ & \\
\hline \multicolumn{18}{|c|}{ Processes relevant also for $S_{\text {LAND }}$} \\
\hline Fire simulation & US only & $\mathrm{N}$ & $\mathrm{N}$ & $\mathrm{Y}$ & $\mathrm{Y}$ & $\mathrm{Y}$ & $\mathrm{N}$ & $\mathrm{Y}$ & $\mathrm{N}$ & $\mathrm{Y}$ & $\mathrm{Y}$ & $\mathrm{Y}$ & $\mathrm{N}$ & $\mathrm{N}$ & $\mathrm{Y}$ & $\mathrm{Y}$ & $\mathrm{Y}$ \\
\hline Climate and variability & $\mathrm{N}$ & $\mathrm{N}$ & $\mathrm{Y}$ & $\mathrm{Y}$ & $\mathrm{Y}$ & $\mathrm{Y}$ & $\mathrm{Y}$ & $\mathrm{Y}$ & $\mathrm{Y}$ & $\mathrm{Y}$ & $\mathrm{Y}$ & $\mathrm{Y}$ & $\mathrm{Y}$ & $\mathrm{Y}$ & $\mathrm{Y}$ & $\mathrm{Y}$ & $\mathrm{Y}$ \\
\hline $\mathrm{CO}_{2}$ fertilisation & $\mathrm{N}^{\mathrm{g}}$ & $\mathrm{N}^{\mathrm{g}}$ & $\mathrm{Y}$ & $\mathrm{Y}$ & $\mathrm{Y}$ & $\mathrm{Y}$ & $\mathrm{Y}$ & $\mathrm{Y}$ & $\mathrm{Y}$ & $\mathrm{Y}$ & $\mathrm{Y}$ & $\mathrm{Y}$ & $\mathrm{Y}$ & $\mathrm{Y}$ & $\mathrm{Y}$ & $\mathrm{Y}$ & $\mathrm{Y}$ \\
\hline $\begin{array}{l}\text { Carbon-nitrogen inter- } \\
\text { actions, including } \mathrm{N} \\
\text { deposition }\end{array}$ & $\mathrm{N}^{\mathrm{i}}$ & $\mathrm{N}^{\mathrm{i}}$ & $\mathrm{Y}$ & $\mathrm{N}^{\mathrm{e}}$ & $\mathrm{Y}$ & $\mathrm{Y}$ & $\mathrm{Y}$ & $\mathrm{N}$ & $\mathrm{N}$ & $\mathrm{Y}$ & $\mathrm{N}$ & $\mathrm{Y}$ & $\mathrm{Y}$ & $\mathrm{N}^{\mathrm{e}}$ & $\mathrm{N}$ & $\mathrm{Y}^{\mathrm{c}}$ & $\mathrm{N}$ \\
\hline
\end{tabular}

${ }^{\text {a }}$ Refers to the routine harvest of established managed forests rather than pools of harvested products.

${ }^{b}$ No back and forth transitions between vegetation types at the country level, but if forest loss based on FRA exceeded agricultural expansion based on FAO, then this amount of area.

${ }^{\mathrm{c}}$ Limited. Nitrogen uptake is simulated as a function of soil C, and Vcmax is an empirical function of canopy N. Does not consider $\mathrm{N}$ deposition.

d Available but not active for comparability between the two LU forcings.

e Although C-N cycle interactions are not represented, the model includes a parameterisation of down-regulation of photosynthesis as $\mathrm{CO}_{2}$ increases to emulate nutrient constraints (Arora et al., 2009).

$\mathrm{f}$ Tillage is represented over croplands by increased soil carbon decomposition rate and reduced humification of litter to soil carbon.

$\mathrm{g}$ Bookkeeping models include effect of $\mathrm{CO}_{2}$ fertilisation as captured by observed carbon densities, but not as an effect transient in time.

h $20 \%$ reduction of active soil organic carbon (SOC) pool turnover time for $\mathrm{C} 3$ crop and $40 \%$ reduction for C4 crops.

${ }^{\mathrm{i}}$ Process captured implicitly by use of observed carbon densities.

$\mathrm{j}$ Three DGVMs were excluded from the $E_{\mathrm{LUC}}$ estimate due to an initial peak of $E_{\mathrm{LUC}}$ emissions caused by a cold start of shifting cultivation in 1860 . 
Table A2. Comparison of the processes included in the global ocean biogeochemistry models for their estimates of $S_{\text {OCEAN }}$. See Table 4 for model references.

\begin{tabular}{|c|c|c|c|c|c|c|c|c|}
\hline & CCSM-BEC & CSIRO & NorESM-OC & MITgcm-REcoM2 & $\begin{array}{l}\text { MPIOM- } \\
\text { HAMOCC }\end{array}$ & $\begin{array}{l}\text { NEMO-PISCES } \\
\text { (CNRM) }\end{array}$ & $\begin{array}{l}\text { NEMO- } \\
\text { PISCES (IPSL) }\end{array}$ & $\begin{array}{l}\text { NEMO- } \\
\text { PlankTOM5 }\end{array}$ \\
\hline $\begin{array}{l}\text { Atmospheric } \\
\text { forcing }\end{array}$ & NCEP & JRA-55 & $\begin{array}{l}\text { CORE-I (spin } \\
\text { up)/NCEP with } \\
\text { CORE-II correc- } \\
\text { tions }\end{array}$ & JRA-55 & ERA-20C & NCEP & NCEP & NCEP \\
\hline $\begin{array}{l}\text { Initialisation } \\
\text { of carbon } \\
\text { chemistry }\end{array}$ & GLODAP & $\begin{array}{l}\text { GLODAP + spin } \\
\text { up } 1000+\text { years }\end{array}$ & $\begin{array}{l}\text { GLODAP v1 + } \\
\text { spin up } 1000 \text { years }\end{array}$ & $\begin{array}{l}\text { GLODAP, then } \\
\text { spin up } 116 \text { years } \\
(2 \text { cycles JRA-55) }\end{array}$ & $\begin{array}{l}\text { from previous } \\
\text { model runs with } \\
>1000 \text { years } \\
\text { spin-up }\end{array}$ & $\begin{array}{l}\text { spin up } 3000 \text { years } \\
\text { offline }+300 \text { years } \\
\text { online }\end{array}$ & $\begin{array}{l}\text { GLODAP } \\
\text { from } 1948 \\
\text { onwards }\end{array}$ & $\begin{array}{l}\text { GLODAP + } \\
\text { spin up } \\
30 \text { years }\end{array}$ \\
\hline $\begin{array}{l}\text { Physical } \\
\text { ocean model }\end{array}$ & $\begin{array}{l}\text { POP Version } \\
1.4 .3\end{array}$ & MOM5 & MICOM & MITgcm 65n & MPIOM & $\begin{array}{l}\text { NEMOv2.4- } \\
\text { ORCA1L42 }\end{array}$ & $\begin{array}{l}\text { NEMOv3.2- } \\
\text { ORCA2L31 }\end{array}$ & $\begin{array}{l}\text { NEMOv2.3- } \\
\text { ORCA2 }\end{array}$ \\
\hline Resolution & $\begin{array}{l}3.6^{\circ} \text { long, } 0.8 \\
\text { to } 1.8^{\circ} \text { lat }\end{array}$ & $\begin{array}{l}1^{\circ} \times 1^{\circ} \text { with } \\
\text { enhanced resolution } \\
\text { at the tropics and } \\
\text { high-lat S. Ocean; } \\
50 \text { levels }\end{array}$ & $\begin{array}{l}1^{\circ} \text { long, } 0.17 \text { to } \\
0.25 \text { lat; } 51 \text { isopyc- } \\
\text { nic layers }+2 \text { bulk } \\
\text { mixed layer }\end{array}$ & $\begin{array}{l}2^{\circ} \text { long, } 0.38-2^{\circ} \\
\text { lat; } 30 \text { levels }\end{array}$ & $\begin{array}{l}1.5^{\circ} \\
40 \text { levels }\end{array}$ & $\begin{array}{l}2^{\circ} \text { long, } 0.3 \text { to } 1^{\circ} \\
\text { lat; } \\
42 \text { levels, } 5 \mathrm{~m} \text { at } \\
\text { surface }\end{array}$ & $\begin{array}{l}2^{\circ} \text { long, } 0.3 \text { to } \\
1.5^{\circ} \text { lat; } \\
31 \text { levels }\end{array}$ & $\begin{array}{l}2^{\circ} \text { long, } 0.3 \\
\text { to } 1.5^{\circ} \text { lat; } \\
31 \text { levels }\end{array}$ \\
\hline
\end{tabular}

Table A3. Comparison of the inversion setup and input fields for the atmospheric inversions. Atmospheric inversions see the full $\mathrm{CO}_{2}$ fluxes, including the anthropogenic and pre-industrial fluxes. Hence, they need to be adjusted for the pre-industrial flux of $\mathrm{CO}_{2}$ from the land to the ocean that is part of the natural carbon cycle before they can be compared with $S_{\text {OCEAN }}$ and $S_{\text {LAND }}$ from process models. See Table 4 for references.

\begin{tabular}{|c|c|c|c|}
\hline & CarbonTracker Europe (CTE) & Jena CarboScope & CAMS \\
\hline Version number & CTE2017-FT & s85oc_v4.1s & v16r1 \\
\hline \multicolumn{4}{|l|}{ Observations } \\
\hline $\begin{array}{l}\text { Atmospheric } \\
\text { observations }\end{array}$ & $\begin{array}{l}\text { Hourly resolution (well- } \\
\text { mixed conditions) ObsPack } \\
\text { GLOBALVIEWplus v2.1 and } \\
\text { NRTv3.3 }\end{array}$ & $\begin{array}{l}\text { Flasks and hourly (outliers } \\
\text { removed by } 2 \sigma \text { criterion) }\end{array}$ & $\begin{array}{l}\text { Daily averages of well-mixed con- } \\
\text { ditions - ObsPack GLOBALVIEW- } \\
\text { plus v2.1 and NRT v3.2.3, WD- } \\
\text { CGG, RAMCES, and ICOS ATC }\end{array}$ \\
\hline \multicolumn{4}{|l|}{ Prior fluxes } \\
\hline Biosphere and fires & SiBCASA-GFED4s ${ }^{b}$ & Zero & $\begin{array}{l}\text { ORCHIDEE (climatological), } \\
\text { GFEDv4 and GFAS }\end{array}$ \\
\hline Ocean & $\begin{array}{l}\text { Ocean inversion by Jacobson et } \\
\text { al. (2007) }\end{array}$ & $\begin{array}{l}p \mathrm{CO}_{2} \text {-based ocean flux product } \\
\text { oc_v1.5 (update of Rödenbeck } \\
\text { et al., 2014) }\end{array}$ & Landschützer et al. (2015) \\
\hline Fossil fuels & $\begin{array}{l}\text { EDGAR and IER, scaled to } \\
\text { CDIAC }\end{array}$ & $\begin{array}{l}\text { CDIAC (extended after } 2013 \\
\text { with GCP totals) }\end{array}$ & EDGAR scaled to CDIAC \\
\hline \multicolumn{4}{|c|}{ Transport and optimisation } \\
\hline Transport model & TM5 & TM3 & LMDZ v5A \\
\hline Weather forcing & ECMWF & NCEP & ECMWF \\
\hline Resolution (degrees) & $\begin{array}{l}\text { Global: } 3^{\circ} \times 2^{\circ} \text {, Europe: } \\
1^{\circ} \times 1^{\circ} \text {, North America: } \\
1^{\circ} \times 1^{\circ}\end{array}$ & Global: $4^{\circ} \times 5^{\circ}$ & Global: $3.75^{\circ} \times 1.875^{\circ}$ \\
\hline Optimisation & Ensemble Kalman filter & $\begin{array}{l}\text { Conjugate gradient } \\
\text { (re-orthonormalisation) }\end{array}$ & Variational \\
\hline
\end{tabular}

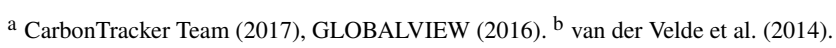


Table A4. Attribution of $f \mathrm{CO}_{2}$ measurements for the year 2016 included in SOCAT v5 (Bakker et al., 2016) to inform ocean $p C \mathrm{O}_{2}$-based flux products.

\begin{tabular}{|c|c|c|c|c|}
\hline $\begin{array}{l}\text { Platform (vessel or } \\
\text { time-series station) }\end{array}$ & Regions & $\begin{array}{r}\text { No. of } \\
\text { samples }\end{array}$ & Principal investigators & $\begin{array}{r}\text { Number of } \\
\text { data sets }\end{array}$ \\
\hline Allure of the Seas & North Atlantic, Tropical Atlantic & 71744 & Wanninkhof, R.; Pierrot, D. & 36 \\
\hline Atlantic Cartier & North Atlantic & 44302 & $\begin{array}{l}\text { Steinhoff, T.; Körtzinger, A.; Becker, M.; } \\
\text { Wallace, D. }\end{array}$ & 12 \\
\hline Aurora Australis & Southern Ocean & 43885 & Tilbrook, B. & 2 \\
\hline Benguela Stream & North Atlantic, Tropical Atlantic & 137902 & Schuster, U.; Watson, A. J. & 21 \\
\hline Cap Blanche & North Pacific, Tropical Pacific & 17913 & Cosca, C.; Alin, S.; Feely, R.; Herndon, J. & 3 \\
\hline Cap San Lorenzo & North Atlantic, Tropical Atlantic & 9126 & Lefèvre, $\mathrm{N}$. & 3 \\
\hline Colibri & North Atlantic, Tropical Atlantic & 27780 & Lefèvre, N. & 6 \\
\hline Equinox & North Atlantic, Tropical Atlantic & 97106 & Wanninkhof, R.; Pierrot, D. & 35 \\
\hline F.G. Walton Smith & North Atlantic, Tropical Atlantic & 43222 & Millero, F.; Wanninkhof, R. & 16 \\
\hline Finnmaid & North Atlantic & 34303 & Rehder, G.; Glockzin, M. & 3 \\
\hline G.O. Sars & Arctic, North Atlantic & 109125 & Skjelvan, I. & 13 \\
\hline GAKOA_149W_60N & North Pacific & 488 & $\begin{array}{l}\text { Cross, J.; Mathis, J.; Monacci, N.; } \\
\text { Musielewicz, S.; Maenner, S.; Osborne, J. }\end{array}$ & 1 \\
\hline Gordon Gunter & North Atlantic, Tropical Atlantic & 59310 & Wanninkhof, R.; Pierrot, D. & 13 \\
\hline Henry B. Bigelow & North Atlantic & 61021 & Wanninkhof, R. & 13 \\
\hline Investigator & Southern Ocean, Tropical Pacific & 108721 & Tilbrook, B. & 3 \\
\hline Laurence M. Gould & Southern Ocean & 26150 & $\begin{array}{l}\text { Sweeney, C.; Takahashi, T.; Newberger, T.; } \\
\text { Sutherland, S. C.; Munro, D. }\end{array}$ & 5 \\
\hline Marion Dufresne & Southern Ocean & 3214 & Metzl, N.; Lo Monaco, C. & 1 \\
\hline New Century 2 & $\begin{array}{l}\text { North Atlantic, North Pacific, } \\
\text { Tropical Pacific }\end{array}$ & 25222 & Nakaoka, S. & 15 \\
\hline Nuka Arctica & North Atlantic & 47392 & $\begin{array}{l}\text { Becker, M.; Olsen, A.; Omar, A.; } \\
\text { Johannessen, T. }\end{array}$ & 12 \\
\hline Polarstern & $\begin{array}{l}\text { Arctic, North Atlantic, Southern } \\
\text { Ocean, Tropical Atlantic }\end{array}$ & 164407 & van Heuven, S.; Hoppema, M. & 5 \\
\hline Roger Revelle & $\begin{array}{l}\text { Indian Ocean, Southern Ocean, } \\
\text { Tropical Pacific }\end{array}$ & 93689 & Wanninkhof, R.; Pierrot, D. & 8 \\
\hline Ronald H. Brown & North Pacific, Tropical Pacific & 52267 & Wanninkhof, R.; Pierrot, D. & 8 \\
\hline S.A. Agulhas II & Southern Ocean & 27851 & Monteiro, P. M. S.; Joubert, W. R. & \\
\hline Sarmiento de Gamboa & $\begin{array}{l}\text { North Atlantic, Southern Ocean, } \\
\text { Tropical Atlantic }\end{array}$ & 16122 & Padin, X. A. & 2 \\
\hline Savannah & North Atlantic & 2803 & Cai, W.-J.; Reimer, J. J. & 1 \\
\hline SEAK & North Pacific & 271 & $\begin{array}{l}\text { Cross, J.; Mathis, J.; Monacci, N.; } \\
\text { Musielewicz, S.; Maenner, S.; Osborne, J. }\end{array}$ & 1 \\
\hline Skogafoss & North Atlantic & 22541 & Wanninkhof, R.; Pierrot, D. & 4 \\
\hline Tangaroa & Southern Ocean & 118997 & Currie, $\mathrm{K}$. & 7 \\
\hline Thomas G. Thompson & North Pacific, Tropical Pacific & 14656 & Alin, S.; Cosca, C.; Herndon, J.; Feely, R. & 1 \\
\hline Trans Future 5 & $\begin{array}{l}\text { North Pacific, Tropical Pacific, } \\
\text { Southern Ocean }\end{array}$ & 23087 & Nakaoka, S.; Nojiri, Y. & 21 \\
\hline UNH Gulf Challenger & North Atlantic & 2984 & Hunt, C. W. & 3 \\
\hline
\end{tabular}


Table A5. Funding supporting the production of the various components of the global carbon budget in addition to the authors' supporting institutions (see also acknowledgements).

\begin{tabular}{|c|c|}
\hline Funder and grant number (where relevant) & Author initials \\
\hline Australia, Integrated Marine Observing System (IMOS) & BT \\
\hline Australian National Environment Science Program (NESP) & JGC, VH \\
\hline EC H2020 European Research Council (ERC) (QUINCY; grant no. 647204). & $\mathrm{SZ}$ \\
\hline EC H2020 ERC Synergy grant (IMBALANCE-P; grant no. ERC-2013-SyG-610028) & $\mathrm{DZ}$ \\
\hline EC H2020 project CRESCENDO (grant no. 641816) & PF, RS \\
\hline EC H2020-MSCA-IF-2015 ERC (FIBER; grant no. 701329) & BDS \\
\hline EC FP7 project HELIX (grant no. 603864) & $\mathrm{PF}, \mathrm{RAB}, \mathrm{SS}$ \\
\hline EU FP7 project LUC4C (grant no. 603542) & $\mathrm{PF}, \mathrm{MK}, \mathrm{SS}$ \\
\hline $\begin{array}{l}\text { French Institut National des Sciences de l'Univers (INSU) and Institut Paul Emile Victor (IPEV), } \\
\text { Sorbonne Universités (UPMC, Univ Paris 06) }\end{array}$ & NM \\
\hline German Federal Ministry for Education and Research (BMBF) & GR, AK, SVH \\
\hline German Federal Ministry of Transport and Digital Infrastructure (BMVI) & $\mathrm{AK}, \mathrm{SVH}$ \\
\hline German Research Foundation's Emmy Noether Programme (grant no. PO1751/1-1) & JEMSN, JP \\
\hline IRD, Integrated Carbon Observation System (ICOS) RI & NL \\
\hline Japan National Institute for Environmental Studies (NIES), Ministry of Environment (MOE) & SK, YN \\
\hline NASA LCLUC programme (grant no. NASA NNX14AD94G) & $\mathrm{AJ}$ \\
\hline Netherlands Organisation for Scientific Research (NWO) Veni grant (016.Veni.171.095) & IvdLL \\
\hline Netherlands Organisation for Scientific Research (NWO) Veni grant (016.Veni.158.021) & KKG \\
\hline New Zealand National Institute of Water and Atmospheric Research (NIWA) Core Funding & $\mathrm{KC}$ \\
\hline Norwegian Research Council, Norwegian Environmental Agency & IS \\
\hline Norwegian Research Council (ICOS 245927) & $\mathrm{BP}, \mathrm{MB}$ \\
\hline Norwegian Research Council (grant no. 229771) & JS \\
\hline Norwegian Research Council (grant no. 209701) & RMA, JIK, GPP \\
\hline RI Integrated Carbon Observation System (ICOS) & AW, GR, AK, SVH, IS, BP, MB \\
\hline $\begin{array}{l}\text { South Africa Council for Scientific and Industrial Research, Department of Science } \\
\text { and Technology (DST) }\end{array}$ & PMSM \\
\hline Swiss National Science Foundation (grant no.200020_172476) & SL \\
\hline The Copernicus Atmosphere Monitoring Service, implemented by the European Centre for & $\mathrm{FC}$ \\
\hline Medium-Range Weather Forecasts (ECMWF) on behalf of the European Commission & \\
\hline UK BEIS/Defra Met Office Hadley Centre Climate Programme (grant no. GA01101) & RAB \\
\hline UK Natural Environment Research Council (SONATA: grant no. NE/P021417/1) & CLQ, OA \\
\hline UK NERC, EU FP7, EU Horizon2020 & AW \\
\hline USA Department of Energy, Office of Science and BER programme (grant no. DE-SC000 0016323) & ATJ \\
\hline USA National Oceanographic and Atmospheric Administration (NOAA) Ocean Acidification & $\mathrm{CWH}$ \\
\hline Program (OAP) NA16NOS0120023 & \\
\hline USA National Science Foundation (grant no. OPP 1543457) & DRM \\
\hline USA National Science Foundation (grant no. AGS 12-43071) & AKJ \\
\hline \multicolumn{2}{|l|}{ Computing resources } \\
\hline Grand Équipement National de Calcul Intensif (allocation x2016016328), France & NV \\
\hline HPC resources of TGCC under allocation 2017-A0010102201 made by GENCI & $\mathrm{FC}$ \\
\hline Météo-France/DSI supercomputing centre & RS \\
\hline Netherlands Organisation for Scientific Research (NWO) (SH-312-14) & IvdLL \\
\hline UEA High Performance Computing Cluster, UK & ODA, CLQ \\
\hline
\end{tabular}


Competing interests. The authors declare that they have no conflict of interest.

Acknowledgements. We thank all people and institutions who provided the data used in this carbon budget; Clare Enright, Wouter Peters, and Shijie Shu for their involvement in the development, use, and analysis of the models and data products used here; and Fortunat Joos, Samar Khatiwala, and Timothy DeVries for providing historical data. We thank Ed Dlugokencky, who provided the atmospheric $\mathrm{CO}_{2}$ measurements used here; Camilla Stegen Landa, Christophe Bernard, and Steve Jones of the Bjerknes Climate Data Centre and the ICOS Ocean Thematic Centre data management at the University of Bergen, who helped with gathering information from the SOCAT community; and all those involved in collecting and providing oceanographic $\mathrm{CO}_{2}$ measurements used here, in particular for the new ocean data for year 2016 (see Table A4). This is NOAA-PMEL contribution number 4728 . We thank the institutions and funding agencies responsible for the collection and quality control of the data included in SOCAT, as well as the support of the International Ocean Carbon Coordination Project (IOCCP), the Surface Ocean Lower Atmosphere Study (SOLAS), and the Integrated Marine Biogeochemistry and Ecosystem Research (IMBER) programme. We thank FAO and its member countries for the collection, analysis, and dissemination of national data through FAOSTAT.

Finally, we thank all funders who have supported the individual and joint contributions to this work (see Appendix Table A5), as well as Martin Heimann, Han Dolman, and Britton Stephens, who reviewed the manuscript and previous versions, and the many researchers who have provided feedback during the GCP community consultation held at the 10th International $\mathrm{CO}_{2}$ Conference in Interlaken, Switzerland, and elsewhere.

Edited by: David Carlson

Reviewed by: Britton Stephens, Albertus J. (Han) Dolman, and one anonymous referee

\section{References}

Andres, R. J., Boden, T. A., Bréon, F.-M., Ciais, P., Davis, S., Erickson, D., Gregg, J. S., Jacobson, A., Marland, G., Miller, J., Oda, T., Olivier, J. G. J., Raupach, M. R., Rayner, P., and Treanton, K.: A synthesis of carbon dioxide emissions from fossil-fuel combustion, Biogeosciences, 9, 1845-1871, https://doi.org/10.5194/bg-9-1845-2012, 2012.

Andres, R. J., Boden, T., and Higdon, D.: A new evaluation of the uncertainty associated with CDIAC estimates of fossil fuel carbon dioxide emission, Tellus B, 66, 23616, https://doi.org/10.3402/tellusb.v66.23616, 2014.

Andrew, R. M.: Global $\mathrm{CO}_{2}$ emissions from cement production, Earth Syst. Sci. Data, 10, 195-217, https://doi.org/10.5194/essd10-195-2018, 2018.

Andrew, R. M. and Peters, G. P.: A multi-region input-output table based on the Global Trade Analysis Project Database (GTAPMRIO), Econ. Syst. Res., 25, 99-121, 2013.

Archer, D., Eby, M., Brovkin, V., Ridgwell, A., Cao, L., Mikolajewicz, U., Caldeira, K. M., K., Munhoven, G., Montenegro, A., and
Tokos, K.: Atmospheric Lifetime of Fossil Fuel Carbon Dioxide, Annu. Rev. Earth Pl. Sc., 37, 117-134, 2009.

Arneth, A., Sitch, S., Pongratz, J., Stocker, B. D., Ciais, P., Poulter, B., Bayer, A. D., Bondeau, A., Calle, L., Chini, L. P., Gasser, T., Fader, M., Friedlingstein, P., Kato, E., Li, W., Lindeskog, M., Nabel, J. E. M. S., Pugh, T. A. M., Robertson, E., Viovy, N., Yue, C., and Zaehle, S.: Historical carbon dioxide emissions caused by land-use changes are possibly larger than assumed, Nat. Geosci., 10, 79-84, 2017.

Arora, V. K., Boer, G. J., Christian, J. R., Curry, C. L., Denman, K. L., Zahariev, K., Flato, G. M., Scinocca, J. F., Merryfield, W. J., and Lee, W. G.: The Effect of Terrestrial Photosynthesis Down Regulation on the Twentieth-Century Carbon Budget Simulated with the CCCma Earth System Model, J. Climate, 22, 6066-6088, 2009.

Aumont, O. and Bopp, L.: Globalizing results from ocean in situ iron fertilization studies, Global Biogeochem. Cy., 20, GB2017, https://doi.org/10.1029/2005GB002591, 2006.

Bakker, D. C. E., Pfeil, B., Landa, C. S., Metzl, N., O'Brien, K. M., Olsen, A., Smith, K., Cosca, C., Harasawa, S., Jones, S. D., Nakaoka, S.-I., Nojiri, Y., Schuster, U., Steinhoff, T., Sweeney, C., Takahashi, T., Tilbrook, B., Wada, C., Wanninkhof, R., Alin, S. R., Balestrini, C. F., Barbero, L., Bates, N. R., Bianchi, A. A., Bonou, F., Boutin, J., Bozec, Y., Burger, E. F., Cai, W.-J., Castle, R. D., Chen, L., Chierici, M., Currie, K., Evans, W., Featherstone, C., Feely, R. A., Fransson, A., Goyet, C., Greenwood, N., Gregor, L., Hankin, S., Hardman-Mountford, N. J., Harlay, J., Hauck, J., Hoppema, M., Humphreys, M. P., Hunt, C. W., Huss, B., Ibánhez, J. S. P., Johannessen, T., Keeling, R., Kitidis, V., Körtzinger, A., Kozyr, A., Krasakopoulou, E., Kuwata, A., Landschützer, P., Lauvset, S. K., Lefèvre, N., Lo Monaco, C., Manke, A., Mathis, J. T., Merlivat, L., Millero, F. J., Monteiro, P. M. S., Munro, D. R., Murata, A., Newberger, T., Omar, A. M., Ono, T., Paterson, K., Pearce, D., Pierrot, D., Robbins, L. L., Saito, S., Salisbury, J., Schlitzer, R., Schneider, B., Schweitzer, R., Sieger, R., Skjelvan, I., Sullivan, K. F., Sutherland, S. C., Sutton, A. J., Tadokoro, K., Telszewski, M., Tuma, M., van Heuven, S. M. A. C., Vandemark, D., Ward, B., Watson, A. J., and Xu, S.: A multidecade record of high-quality $f \mathrm{CO}_{2}$ data in version 3 of the Surface Ocean $\mathrm{CO}_{2}$ Atlas (SOCAT), Earth Syst. Sci. Data, 8, 383413, https://doi.org/10.5194/essd-8-383-2016, 2016.

Ballantyne, A. P., Alden, C. B., Miller, J. B., Tans, P. P., and White, J. W. C.: Increase in observed net carbon dioxide uptake by land and oceans during the last 50 years, Nature, 488, 70-72, 2012.

Ballantyne, A. P., Andres, R., Houghton, R., Stocker, B. D., Wanninkhof, R., Anderegg, W., Cooper, L. A., DeGrandpre, M., Tans, P. P., Miller, J. B., Alden, C., and White, J. W. C.: Audit of the global carbon budget: estimate errors and their impact on uptake uncertainty, Biogeosciences, 12, 2565-2584, https://doi.org/10.5194/bg-12-2565-2015, 2015.

Bauer, J. E., Cai, W.-J., Raymond, P. A., Bianchi, T. S., Hopkinson, C. S., and Regnier, P. A. G.: The changing carbon cycle of the coastal ocean, Nature, 504, 61-70, 2013.

Best, M. J., Pryor, M., Clark, D. B., Rooney, G. G., Essery, R. L. H., Ménard, C. B., Edwards, J. M., Hendry, M. A., Porson, A., Gedney, N., Mercado, L. M., Sitch, S., Blyth, E., Boucher, O., Cox, P. M., Grimmond, C. S. B., and Harding, R. J.: The Joint UK Land Environment Simulator (JULES), model description - 
Part 1: Energy and water fluxes, Geosci. Model Dev., 4, 677-699, https://doi.org/10.5194/gmd-4-677-2011, 2011.

Betts, R. A., Jones, C. D., Knight, J. R., Keeling, R. F., and Kennedy, J. J.: El Nino and a record $\mathrm{CO}_{2}$ rise, Nature Clim. Change, 6 , 806-810, 2016.

Boden, T. A., Marland, G., and Andres, R. J.: Global, Regional, and National Fossil-Fuel $\mathrm{CO}_{2}$ Emissions, Oak Ridge National Laboratory, U.S. Department of Energy, Oak Ridge, Tenn., USA, available at: http://cdiac.ornl.gov/trends/emis/overview_ 2014.html, last access: 28 June 2017.

BP: BP Statistical Review of World Energy June 2017, available at: https://www.bp.com/content/dam/bp/en/ corporate/pdf/energy-economics/statistical-review-2017/

bp-statistical-review-of-world-energy-2017-full-report.pdf, last access: 13 June 2017.

Bruno, M. and Joos, F.: Terrestrial carbon storage during the past 200 years: A monte carlo analysis of $\mathrm{CO}_{2}$ data from ice core and atmospheric measurements, Global Biogeochem. Cy., 11, 111124, 1997.

Buitenhuis, E. T., Rivkin, R. B., Sailley, S., and Le Quéré, C.: Biogeochemical fluxes through microzooplankton, Global Biogeochem. Cy., 24, GB4015, https://doi.org/10.1029/2009GB003601, 2010.

Canadell, J. G., Le Quéré, C., Raupach, M. R., Field, C. B., Buitenhuis, E. T., Ciais, P., Conway, T. J., Gillett, N. P., Houghton, R. A., and Marland, G.: Contributions to accelerating atmospheric $\mathrm{CO}_{2}$ growth from economic activity, carbon intensity, and efficiency of natural sinks, P. Natl. Acad. Sci. USA, 104, 1886618870, 2007.

Canadell, J. G., Ciais, P., Sabine, C., and Joos, F. (Eds.): REgional Carbon Cycle Assessment and Processes (RECCAP), Biogeosciences, http://www.biogeosciences.net/special_issue107.html, 2012.

CarbonTracker Team: Compilation of near real time atmospheric carbon dioxide data provided by NOAA and EC; obspack_co2_1_NRT_v3.3_2017-04-19; NOAA Earth System Research Laboratory, Global Monitoring Division, https://doi.org/10.15138/G3G01J, 2017.

CCIA: Analysis of current economic trend of coal in China, China Coal Industry Association (CCIA), 2017, available at: http: //www.coalchina.org.cn/detail/17/07/24/00000025/content.html, last access: 15 September 2017 (in Chinese).

CEA: Daily Coal - Archive, Central Electricity Authority (CEA), 2017, available at: http://www.cea.nic.in/dailyarchive.html, last access: 2 October 2017.

Chevallier, F.: On the statistical optimality of $\mathrm{CO}_{2}$ atmospheric inversions assimilating $\mathrm{CO}_{2}$ column retrievals, Atmos. Chem. Phys., 15, 11133-11145, https://doi.org/10.5194/acp-15-11133$2015,2015$.

Chevallier, F., Fisher, M., Peylin, P., Serrar, S., Bousquet, P., Bréon, F.-M., Chédin, A., and Ciais, P.: Inferring $\mathrm{CO}_{2}$ sources and sinks from satellite observations: Method and application to TOVS data, J. Geophys. Res., 110, D24309, https://doi.org/10.1029/2005JD006390, 2005.

Ciais, P., Sabine, C., Govindasamy, B., Bopp, L., Brovkin, V., Canadell, J., Chhabra, A., DeFries, R., Galloway, J., Heimann, M., Jones, C., Le Quéré, C., Myneni, R., Piao, S., and Thornton, P.: Chapter 6: Carbon and Other Biogeochemical Cycles, in: Climate Change 2013 The Physical Science Basis, edited by:
Stocker, T., Qin, D., and Platner, G.-K., Cambridge University Press, Cambridge, UK, 2013.

CIL: Production and Offtake Performance of CIL and Subsidiary Companies, Coal India Limited, 2017, available at: https://www. coalindia.in/en-us/performance/physical.aspx, last access: 2 October 2017

Clark, D. B., Mercado, L. M., Sitch, S., Jones, C. D., Gedney, N., Best, M. J., Pryor, M., Rooney, G. G., Essery, R. L. H., Blyth, E., Boucher, O., Harding, R. J., Huntingford, C., and Cox, P. M.: The Joint UK Land Environment Simulator (JULES), model description - Part 2: Carbon fluxes and vegetation dynamics, Geosci. Model Dev., 4, 701-722, https://doi.org/10.5194/gmd-4701-2011, 2011.

Cox, P. M., Pearson, D., Booth, B. B., Friedlingstein, P., Huntingford, C., Jones, C. D., and Luke, C. M.: Sensitivity of tropical carbon to climate change constrained by carbon dioxide variability, Nature, 494, 341-344, 2013.

Davis, S. J. and Caldeira, K.: Consumption-based accounting of $\mathrm{CO}_{2}$ emissions, P. Natl. Acad. Sci. USA, 107, 5687-5692, 2010.

Denman, K. L., Brasseur, G., Chidthaisong, A., Ciais, P., Cox, P. M., Dickinson, R. E., Hauglustaine, D., Heinze, C., Holland, E., Jacob, D., Lohmann, U., Ramachandran, S., Leite da Silva Dias, P., Wofsy, S. C., and Zhang, X.: Couplings Between Changes in the Climate System and Biogeochemistry. In: Climate Change 2007: The Physical Science Basis. Contribution of Working Group I to the Fourth Assessment Report of the Intergovernmental Panel on Climate Change, edited by: Solomon, S., Qin, D., Manning, M., Marquis, M., Averyt, K., Tignor, M. M. B., Miller, H. L., and Chen, Z. L., Cambridge University Press, Cambridge, UK and New York, USA, 2007.

DeVries, T.: The oceanic anthropogenic $\mathrm{CO}_{2}$ sink: Storage, airsea fluxes, and transports over the industrial era, Global Biogeochem. Cy., 28, 631-647, 2014.

DeVries, T., Holzer, M., and Primeau, F.: Recent increase in oceanic carbon uptake driven by weaker upper-ocean overturning, Nature, 542, 215-218, 2017.

Dlugokencky, E. and Tans, P.: Trends in atmospheric carbon dioxide, National Oceanic \& Atmospheric Administration, Earth System Research Laboratory (NOAA/ESRL), available at: http: //www.esrl.noaa.gov/gmd/ccgg/trends/global.html, last access: 9 March 2018.

Doney, S. C., Lima, I., Feely, R. A., Glover, D. M., Lindsay, K., Mahowald, N., Moore, J. K., and Wanninkhof, R.: Mechanisms governing interannual variability in upper-ocean inorganic carbon system and air-sea $\mathrm{CO}_{2}$ fluxes: Physical climate and atmospheric dust, Deep-Sea Res. Pt. II, 56, 640-655, 2009.

Duce, R. A., LaRoche, J., Altieri, K., Arrigo, K. R., Baker, A. R., Capone, D. G., Cornell, S., Dentener, F., Galloway, J., Ganeshram, R. S., Geider, R. J., Jickells, T., Kuypers, M. M., Langlois, R., Liss, P. S., Liu, S. M., Middelburg, J. J., Moore, C. M., Nickovic, S., Oschlies, A., Pedersen, T., Prospero, J., Schlitzer, R., Seitzinger, S., Sorensen, L. L., Uematsu, M., Ulloa, O., Voss, M., Ward, B., and Zamora, L.: Impacts of atmospheric anthropogenic nitrogen on the open ocean, Science, 320, 893-897, 2008.

Dufour, C. O., Le Sommer, J., Gehlen, M., Orr, J. C., Molines, J. M., Simeon, J., and Barnier, B.: Eddy compensation and controls of the enhanced sea-to-air $\mathrm{CO}_{2}$ flux during positive phases of the 
Southern Annular Mode, Global Biogeochem. Cy., 27, 950-961, 2013.

Durant, A. J., Le Quéré, C., Hope, C., and Friend, A. D.: Economic value of improved quantification in global sources and sinks of carbon dioxide, Phil. Trans. A, 269, 1967-1979, 2011.

EIA: Short-Term Energy and Winter Fuels Outlook, U.S. Energy Information Administration, available at: http://www.eia.gov/ forecasts/steo/outlook.cfm, last access: 11 October 2017.

Erb, K.-H., Kastner, T., Luyssaert, S., Houghton, R. A., Kuemmerle, T., Olofsson, P., and Haberl, H.: Bias in the attribution of forest carbon sinks, Nature Clim. Change, 3, 854-856, 2013.

Etheridge, D. M., Steele, L. P., Langenfelds, R. L., and Francey, R. J.: Natural and anthropogenic changes in atmospheric $\mathrm{CO}_{2}$ over the last 1000 years from air in Antarctic ice and firn, J. Geophys. Res., 101, 4115-4128, 1996.

FAO: Global Forest Resources Assessment 2015, Food and Agriculture Organization of the United Nations, Rome, Italy, 2015.

FAOSTAT: Land Use Dataset, Food and Agriculture Organization Statistics Division, available at: http://www.fao.org/faostat/en/ \#data/RL (last access: March 2017), 2015.

Francey, R. J., Trudinger, C. M., van der Schoot, M., Law, R. M., Krummel, P. B., Langenfelds, R. L., Steele, L. P., Allison, C. E., Stavert, A. R., Andres, R. J., and Rodenbeck, C.: Reply to "Anthropogenic $\mathrm{CO}_{2}$ emissions", Nature Clim. Change, 3, 604604, 2013.

Friedlingstein, P., Houghton, R. A., Marland, G., Hackler, J., Boden, T. A., Conway, T. J., Canadell, J. G., Raupach, M. R., Ciais, P., and Le Quéré, C.: Update on $\mathrm{CO}_{2}$ emissions, Nat. Geosci., 3, 811-812, 2010.

Friedlingstein, P., Andrew, R. M., Rogelj, J., Peters, G. P., Canadell, J. G., Knutti, R., Luderer, G., Raupach, M. R., Schaeffer, M., van Vuuren, D. P., and Le Quéré, C.: Persistent growth of $\mathrm{CO}_{2}$ emissions and implications for reaching climate targets, Nat. Geosci., 7, 709-715, 2014.

Gasser, T., Ciais, P., Boucher, O., Quilcaille, Y., Tortora, M., Bopp, L., and Hauglustaine, D.: The compact Earth system model OSCAR v2.2: description and first results, Geosci. Model Dev., 10, 271-319, https://doi.org/10.5194/gmd-10-271-2017, 2017.

GCP: The Global Carbon Budget 2007, available at: http://www. globalcarbonproject.org/carbonbudget/archive.htm (last access: 7 November 2016), 2007.

GCP: Global Carbon Budget 2017, ICOS Carbon Portal, https://doi.org/10.18160/GCP-2017, 2017.

Giglio, L., Descloitres, J., Justice, C. O., and Kaufman, Y. J.: An enhanced contextual fire detection algorithm for MODIS, Remote Sens. Environ., 87, 273-282, 2003.

Gitz, V. and Ciais, P.: Amplifying effects of land-use change on future atmospheric $\mathrm{CO}_{2}$ levels, Global Biogeochem. Cy., 17, 1024, https://doi.org/10.1029/2002GB001963, 2003.

GLOBALVIEW: Cooperative Global Atmospheric Data Integration Project; Multi-laboratory compilation of atmospheric carbon dioxide data for the period 1957-2015; obspack_co2_1_GLOBALVIEWplus_v2.1_2016_09_02; NOAA Earth System Research Laboratory, Global Monitoring Division, https://doi.org/10.15138/G3059Z, 2016.

Goll, D. S., Brovkin, V., Liski, J., Raddatz, T., Thum, T., and ToddBrown, K. E. O.: Strong dependence of $\mathrm{CO}_{2}$ emissions from anthropogenic land cover change on initial land cover and soil car- bon parametrization, Global Biogeochem. Cy., 29, 1511-1523, https://doi.org/10.1002/2014GB004988, 2015.

Gregg, J. S., Andres, R. J., and Marland, G.: China: Emissions pattern of the world leader in $\mathrm{CO}_{2}$ emissions from fossil fuel consumption and cement production, Geophys. Res. Lett., 35, L08806, https://doi.org/10.1029/2007GL032887, 2008.

Guimberteau, M., Zhu, D., Maignan, F., Huang, Y., Yue, C., DantecNédélec, S., Ottlé, C., Jornet-Puig, A., Bastos, A., Laurent, P., Goll, D., Bowring, S., Chang, J., Guenet, B., Tifafi, M., Peng, S., Krinner, G., Ducharne, A., Wang, F., Wang, T., Wang, X., Wang, Y., Yin, Z., Lauerwald, R., Joetzjer, E., Qiu, C., Kim, H., and Ciais, P.: ORCHIDEE-MICT (v8.4.1), a land surface model for the high latitudes: model description and validation, Geosci. Model Dev., 11, 121-163, https://doi.org/10.5194/gmd-11-1212018, 2018.

Hansis, E., Davis, S. J., and Pongratz, J.: Relevance of methodological choices for accounting of land use change carbon fluxes, Global Biogeochem. Cy., 29, 1230-1246, 2015.

Harris, I., Jones, P. D., Osborn, T. J., and Lister, D. H.: Updated high-resolution grids of monthly climatic observations - the CRU TS3.10 Dataset, Int. J. Climatol., 34, 623-642, 2014.

Hauck, J., Köhler, P., Wolf-Gladrow, D., and Völker, C.: Iron fertilisation and century-scale effects of open ocean dissolution of olivine in a simulated $\mathrm{CO}_{2}$ removal experiment, Environ. Res. Lett., 11, 024007, https://doi.org/10.1088/17489326/11/2/024007, 2016.

Haverd, V., Smith, B., Nieradzik, L., Briggs, P. R., Woodgate, W., Trudinger, C. M., and Canadell, J. G.: A new version of the CABLE land surface model (Subversion revision r4546), incorporating land use and land cover change, woody vegetation demography and a novel optimisation-based approach to plant coordination of electron transport and carboxylation capacity-limited photosynthesis, Geosci. Model Dev. Discuss., https://doi.org/10.5194/gmd-2017-265, in review, 2017.

Hertwich, E. G. and Peters, G. P.: Carbon Footprint of Nations: A Global, Trade-Linked Analysis, Environ. Sci. Technol., 43, 6414-6420, https://doi.org/10.1021/es803496a, 2009.

Hooijer, A., Page, S., Canadell, J. G., Silvius, M., Kwadijk, J., Wösten, H., and Jauhiainen, J.: Current and future $\mathrm{CO}_{2}$ emissions from drained peatlands in Southeast Asia, Biogeosciences, 7, 1505-1514, https://doi.org/10.5194/bg-7-1505-2010, 2010.

Houghton, R. A.: Revised estimates of the annual net flux of carbon to the atmosphere from changes in land use and land management 1850-2000, Tellus B, 55, 378-390, 2003.

Houghton, R. A. and Nassikas, A. A.: Global and regional fluxes of carbon from land use and land cover change 1850-2015, Global Biogeochem. Cy., 31, 456-472, 2017.

Houghton, R. A., House, J. I., Pongratz, J., van der Werf, G. R., DeFries, R. S., Hansen, M. C., Le Quéré, C., and Ramankutty, N.: Carbon emissions from land use and land-cover change, Biogeosciences, 9, 5125-5142, https://doi.org/10.5194/bg-9-51252012, 2012.

Hourdin, F., Musat, I., Bony, S., Braconnot, P., Codron, F., Dufresne, J.-1., Fairhead, L., Filiberti, M.-A., Freidlingstein, P., Grandpeix, J.-Y., Krinner, G., LeVan, P., Li, Z.-X., and Lott, F.: The LMDZ4 general circulation model: climate performance and sensitivity to parametrized physics with emphasis on tropical convection, Clim. Dynam., 27, 787-813, 2006. 
Hurtt, G. C., Chini, L. P., Frolking, S., Betts, R. A., Feddema, J., Fischer, G., Fisk, J. P., Hibbard, K., Houghton, R. A., Janetos, A., Jones, C. D., Kindermann, G., Kinoshita, T., Klein Goldewijk, K., Riahi, K., Shevliakova, E., Smith, S., Stehfest, E., Thomson, A., Thornton, P., van Vuuren, D. P., and Wang, Y. P.: Harmonization of land-use scenarios for the period 1500-2100: 600 years of global gridded annual land-use transitions, wood harvest, and resulting secondary lands, Climatic Change, 109, 117-161, 2011.

Hurtt, G. C., Chini, L., Sahajpal, R., and Frolking, S.: Harmonization of global land-use change and management for the period 850-2100, Geosci. Model Dev., in preparation, 2018.

IEA/OECD: $\mathrm{CO}_{2}$ emissions from fuel combustion, International Energy Agency/Organisation for Economic Cooperation and Development, Paris, France, 2016.

Ilyina, T., Six, K., Segschneider, J., Maier-Reimer, E., Li, H., and Núñez-Riboni, I.: The global ocean biogeochemistry model HAMOCC: Model architecture and performance as component of the MPI-Earth System Model in different CMIP5 experimental realizations, J. Adv. Model. Earth Sy., 5, 287-315, 2013.

IMF: World Economic Outlook of the International Monetary Fund, available at: http://www.imf.org/external/ns/cs.aspx?id=29, last access: 10 October 2017.

IPCC: 2006 IPCC Guidelines for National Greenhouse Gas Inventories, Prepared by the National Greenhouse Gas Inventories Programme, Institute for Global Environmental Strategies (IGES), Hayama, Kanagawa, Japan, 2006.

Ito, A. and Inatomi, M.: Use of a process-based model for assessing the methane budgets of global terrestrial ecosystems and evaluation of uncertainty, Biogeosciences, 9, 759-773, https://doi.org/10.5194/bg-9-759-2012, 2012.

Jackson, R. B., Canadell, J. G., Le Quéré, C., Andrew, R. M., Korsbakken, J. I., Peters, G. P., and Nakicenovic, N.: Reaching peak emissions, Nature Clim. Change, 6, 7-10, 2016.

Jackson, R. B., Le Quéré, C., Andrew, R. M., Canadell, J. G., Peters, G. P., Roy, J., and Wu, L.: Warning signs for stabilizing global $\mathrm{CO}_{2}$ emissions, Environ. Res. Lett., 12, 110202, https://doi.org/10.1088/1748-9326/aa9662, 2017.

Jacobson, A. R., Mikaloff Fletcher, S. E., Gruber, N., Sarmiento, J. L., and Gloor, M.: A joint atmosphere-ocean inversion for surface fluxes of carbon dioxide: 1. Methods and global-scale fluxes, Global Biogeochem. Cy., 21, GB1019, https://doi.org/10.1029/2005GB002556, 2007.

Jain, A. K., Meiyappan, P., Song, Y., and House, J. I.: $\mathrm{CO}_{2}$ Emissions from Land-Use Change Affected More by Nitrogen Cycle, than by the Choice of Land Cover Data, Glob. Change Biol., 9, 2893-2906, 2013.

Joos, F. and Spahni, R.: Rates of change in natural and anthropogenic radiative forcing over the past 20000 years, P. Natl. Acad. Sci. USA, 105, 1425-1430, 2008.

Kato, E., Kinoshita, T., Ito, A., Kawamiya, M., and Yamagata, Y.: Evaluation of spatially explicit emission scenario of land-use change and biomass burning using a process-based biogeochemical model, J. Land Use Sci., 8, 104-122, 2013.

Kattge, J., Knorr, W., Raddatz, T., and Wirth, C.: Quantifying photosynthetic capacity and its relationship to leaf nitrogen content for global-scale terrestrial biosphere models, Glob. Change Biol., 15, 976-991, https://doi.org/10.1111/j.1365-2486.2008.01744.x, 2009.
Keeling, C. D., Bacastow, R. B., Bainbridge, A. E., Ekdhal, C. A., Guenther, P. R., and Waterman, L. S.: Atmospheric carbon dioxide variations at Mauna Loa Observatory, Hawaii, Tellus, 28, 538-551, 1976.

Keeling, R. F. and Manning, A. C.: 5.15 - Studies of Recent Changes in Atmospheric $\mathrm{O}_{2}$ Content. In: Treatise on Geochemistry: Second Edition, edited by: Holland, H. D. and Turekian, K. K., Elsevier, Oxford, UK, 2014

Keller, K. M., Lienert, S., Bozbiyik, A., Stocker, T. F., Churakova (Sidorova), O. V., Frank, D. C., Klesse, S., Koven, C. D., Leuenberger, M., Riley, W. J., Saurer, M., Siegwolf, R., Weigt, R. B., and Joos, F.: 20th century changes in carbon isotopes and water-use efficiency: tree-ring-based evaluation of the CLM4.5 and LPX-Bern models, Biogeosciences, 14, 26412673, https://doi.org/10.5194/bg-14-2641-2017, 2017.

Khatiwala, S., Primeau, F., and Hall, T.: Reconstruction of the history of anthropogenic $\mathrm{CO}_{2}$ concentrations in the ocean, Nature, 462, 346-350, 2009.

Khatiwala, S., Tanhua, T., Mikaloff Fletcher, S., Gerber, M., Doney, S. C., Graven, H. D., Gruber, N., McKinley, G. A., Murata, A., Ríos, A. F., and Sabine, C. L.: Global ocean storage of anthropogenic carbon, Biogeosciences, 10, 2169-2191, https://doi.org/10.5194/bg-10-2169-2013, 2013.

Kirschke, S., Bousquet, P., Ciais, P., Saunois, M., Canadell, J. G., Dlugokencky, E. J., Bergamaschi, P., Bergmann, D., Blake, D. R., Bruhwiler, L., Cameron Smith, P., Castaldi, S., Chevallier, F., Feng, L., Fraser, A., Heimann, M., Hodson, E. L., Houweling, S., Josse, B., Fraser, P. J., Krummel, P. B., Lamarque, J., Langenfelds, R. L., Le Quéré, C., Naik, V., O’Doherty, S., Palmer, P. I., Pison, I., Plummer, D., Poulter, B., Prinn, R. G., Rigby, M., Ringeval, B., Santini, M., Schmidt, M., Shindell, D. T., Simpson, I. J., Spahni, R., Steele, L. P., Strode, S. A., Sudo, K., Szopa, S., van der Werf, G. R., Voulgarakis, A., van Weele, M., Weiss, R. F., Williams, J. E., and Zeng, G.: Three decades of global methane sources and sinks, Nat. Geosci., 6, 813-823, 2013.

Klein Goldewijk, K., Beusen, A., Doelman, J., and Stehfest, E.: Anthropogenic land use estimates for the Holocene - HYDE 3.2, Earth Syst. Sci. Data, 9, 927-953, https://doi.org/10.5194/essd9-927-2017, 2017a.

Klein Goldewijk, K., Dekker, S. C., and van Zanden, J. L.: Percapita estimations of long-term historical land use and the consequences for global change research, J. Land Use Sci., 12, 313 337, 2017b.

Korsbakken, J. I., Peters, G. P., and Andrew, R. M.: Uncertainties around reductions in China's coal use and $\mathrm{CO}_{2}$ emissions, Nature Clim. Change, 6, 687-690, 2016.

Krinner, G., Viovy, N., de Noblet, N., Ogée, J., Friedlingstein, P., Ciais, P., Sitch, S., Polcher, J., and Prentice, I. C.: A dynamic global vegetation model for studies of the coupled atmospherebiosphere system, Global Biogeochem. Cy., 19, 1-33, 2005.

Landschützer, P., Gruber, N., Bakker, D. C. E., and Schuster, U.: Recent variability of the global ocean carbon sink, Global Biogeochem. Cy., 28, 927-949, https://doi.org/10.1002/2014GB004853, 2014.

Landschützer, P., Gruber, N., Haumann, A., Rödenbeck, C., Bakker, D. C. E., van Heuven, S., Hoppema, M., Metzl, N., Sweeney, C., Takahashi, T., Tilbrook, B., and Wanninkhof, R.: The reinvigoration of the Southern Ocean carbon sink, Science, 349, 12211224, 2015. 
Landschützer, P., Gruber, N., and Bakker, D. C. E.: Decadal variations and trends of the global ocean carbon sink, Global Biogeochem. Cy., 30, 1396-1417, 2016.

Law, R. M., Ziehn, T., Matear, R. J., Lenton, A., Chamberlain, M. A., Stevens, L. E., Wang, Y.-P., Srbinovsky, J., Bi, D., Yan, H., and Vohralik, P. F.: The carbon cycle in the Australian Community Climate and Earth System Simulator (ACCESS-ESM1) Part 1: Model description and pre-industrial simulation, Geosci. Model Dev., 10, 2567-2590, https://doi.org/10.5194/gmd-102567-2017, 2017.

Le Quéré, C.: Closing the global budget for $\mathrm{CO}_{2}$, Global Change, 74, 28-31, 2009.

Le Quéré, C., Raupach, M. R., Canadell, J. G., Marland, G., Bopp, L., Ciais, P., Conway, T. J., Doney, S. C., Feely, R. A., Foster, P., Friedlingstein, P., Gurney, K., Houghton, R. A., House, J. I., Huntingford, C., Levy, P. E., Lomas, M. R., Majkut, J., Metzl, N., Ometto, J. P., Peters, G. P., Prentice, I. C., Randerson, J. T., Running, S. W., Sarmiento, J. L., Schuster, U., Sitch, S., Takahashi, T., Viovy, N., van der Werf, G. R., and Woodward, F. I.: Trends in the sources and sinks of carbon dioxide, Nat. Geosci., 2, 831-836, 2009.

Le Quéré, C., Andres, R. J., Boden, T., Conway, T., Houghton, R. A., House, J. I., Marland, G., Peters, G. P., van der Werf, G. R., Ahlström, A., Andrew, R. M., Bopp, L., Canadell, J. G., Ciais, P., Doney, S. C., Enright, C., Friedlingstein, P., Huntingford, C., Jain, A. K., Jourdain, C., Kato, E., Keeling, R. F., Klein Goldewijk, K., Levis, S., Levy, P., Lomas, M., Poulter, B., Raupach, M. R., Schwinger, J., Sitch, S., Stocker, B. D., Viovy, N., Zaehle, S., and Zeng, N.: The global carbon budget 1959-2011, Earth Syst. Sci. Data, 5, 165-185, https://doi.org/10.5194/essd-5-1652013, 2013.

Le Quéré, C., Peters, G. P., Andres, R. J., Andrew, R. M., Boden, T. A., Ciais, P., Friedlingstein, P., Houghton, R. A., Marland, G., Moriarty, R., Sitch, S., Tans, P., Arneth, A., Arvanitis, A., Bakker, D. C. E., Bopp, L., Canadell, J. G., Chini, L. P., Doney, S. C., Harper, A., Harris, I., House, J. I., Jain, A. K., Jones, S. D., Kato, E., Keeling, R. F., Klein Goldewijk, K., Körtzinger, A., Koven, C., Lefèvre, N., Maignan, F., Omar, A., Ono, T., Park, G.-H., Pfeil, B., Poulter, B., Raupach, M. R., Regnier, P., Rödenbeck, C., Saito, S., Schwinger, J., Segschneider, J., Stocker, B. D., Takahashi, T., Tilbrook, B., van Heuven, S., Viovy, N., Wanninkhof, R., Wiltshire, A., and Zaehle, S.: Global carbon budget 2013, Earth Syst. Sci. Data, 6, 235-263, https://doi.org/10.5194/essd6-235-2014, 2014.

Le Quéré, C., Moriarty, R., Andrew, R. M., Canadell, J. G., Sitch, S., Korsbakken, J. I., Friedlingstein, P., Peters, G. P., Andres, R. J., Boden, T. A., Houghton, R. A., House, J. I., Keeling, R. F., Tans, P., Arneth, A., Bakker, D. C. E., Barbero, L., Bopp, L., Chang, J., Chevallier, F., Chini, L. P., Ciais, P., Fader, M., Feely, R. A., Gkritzalis, T., Harris, I., Hauck, J., Ilyina, T., Jain, A. K., Kato, E., Kitidis, V., Klein Goldewijk, K., Koven, C., Landschützer, P., Lauvset, S. K., Lefèvre, N., Lenton, A., Lima, I. D., Metzl, N., Millero, F., Munro, D. R., Murata, A., Nabel, J. E. M. S., Nakaoka, S., Nojiri, Y., O’Brien, K., Olsen, A., Ono, T., Pérez, F. F., Pfeil, B., Pierrot, D., Poulter, B., Rehder, G., Rödenbeck, C., Saito, S., Schuster, U., Schwinger, J., Séférian, R., Steinhoff, T., Stocker, B. D., Sutton, A. J., Takahashi, T., Tilbrook, B., van der Laan-Luijkx, I. T., van der Werf, G. R., van Heuven, S., Vandemark, D., Viovy, N., Wiltshire, A., Zaehle, S., and Zeng, N.:
Global Carbon Budget 2015, Earth Syst. Sci. Data, 7, 349-396, https://doi.org/10.5194/essd-7-349-2015, 2015a.

Le Quéré, C., Moriarty, R., Andrew, R. M., Peters, G. P., Ciais, P., Friedlingstein, P., Jones, S. D., Sitch, S., Tans, P., Arneth, A., Boden, T. A., Bopp, L., Bozec, Y., Canadell, J. G., Chini, L. P., Chevallier, F., Cosca, C. E., Harris, I., Hoppema, M., Houghton, R. A., House, J. I., Jain, A. K., Johannessen, T., Kato, E., Keeling, R. F., Kitidis, V., Klein Goldewijk, K., Koven, C., Landa, C. S., Landschützer, P., Lenton, A., Lima, I. D., Marland, G., Mathis, J. T., Metzl, N., Nojiri, Y., Olsen, A., Ono, T., Peng, S., Peters, W., Pfeil, B., Poulter, B., Raupach, M. R., Regnier, P., Rödenbeck, C., Saito, S., Salisbury, J. E., Schuster, U., Schwinger, J., Séférian, R., Segschneider, J., Steinhoff, T., Stocker, B. D., Sutton, A. J., Takahashi, T., Tilbrook, B., van der Werf, G. R., Viovy, N., Wang, Y.-P., Wanninkhof, R., Wiltshire, A., and Zeng, N.: Global carbon budget 2014, Earth Syst. Sci. Data, 7, 47-85, https://doi.org/10.5194/essd-7-47-2015, 2015b.

Le Quéré, C., Andrew, R. M., Canadell, J. G., Sitch, S., Korsbakken, J. I., Peters, G. P., Manning, A. C., Boden, T. A., Tans, P. P., Houghton, R. A., Keeling, R. F., Alin, S., Andrews, O. D., Anthoni, P., Barbero, L., Bopp, L., Chevallier, F., Chini, L. P., Ciais, P., Currie, K., Delire, C., Doney, S. C., Friedlingstein, P., Gkritzalis, T., Harris, I., Hauck, J., Haverd, V., Hoppema, M., Klein Goldewijk, K., Jain, A. K., Kato, E., Körtzinger, A., Landschützer, P., Lefèvre, N., Lenton, A., Lienert, S., Lombardozzi, D., Melton, J. R., Metzl, N., Millero, F., Monteiro, P. M. S., Munro, D. R., Nabel, J. E. M. S., Nakaoka, S.-I., O’Brien, K., Olsen, A., Omar, A. M., Ono, T., Pierrot, D., Poulter, B., Rödenbeck, C., Salisbury, J., Schuster, U., Schwinger, J., Séférian, R., Skjelvan, I., Stocker, B. D., Sutton, A. J., Takahashi, T., Tian, H., Tilbrook, B., van der Laan-Luijkx, I. T., van der Werf, G. R., Viovy, N., Walker, A. P., Wiltshire, A. J., and Zaehle, S.: Global Carbon Budget 2016, Earth Syst. Sci. Data, 8, 605-649, https://doi.org/10.5194/essd-8-605-2016, 2016.

Li, W., Ciais, P., Peng, S., Yue, C., Wang, Y., Thurner, M., Saatchi, S. S., Arneth, A., Avitabile, V., Carvalhais, N., Harper, A. B., Kato, E., Koven, C., Liu, Y. Y., Nabel, J. E. M. S., Pan, Y., Pongratz, J., Poulter, B., Pugh, T. A. M., Santoro, M., Sitch, S., Stocker, B. D., Viovy, N., Wiltshire, A., Yousefpour, R., and Zaehle, S.: Land-use and land-cover change carbon emissions between 1901 and 2012 constrained by biomass observations, Biogeosciences, 14, 5053-5067, https://doi.org/10.5194/bg-145053-2017, 2017.

Liu, Z., Guan, D., Wei, W., Davis, S. J., Ciais, P., Bai, J., Peng, S., Zhang, Q., Hubacek, K., Marland, G., Andres, R. J., CrawfordBrown, D., Lin, J., Zhao, H., Hong, C., Boden, T. A., Feng, K., Peters, G. P., Xi, F., Liu, J., Li, Y., Zhao, Y., Zeng, N., and He, K.: Reduced carbon emission estimates from fossil fuel combustion and cement production in China, Nature, 524, 335-338, 2015.

Lloyd, J. and Taylor, J.: On the Temperature Dependence of Soil Respiration, Funct. Ecol., 8, 315-323, https://doi.org/10.2307/2389824, 1994.

Manning, A. C. and Keeling, R. F.: Global oceanic and land biotic carbon sinks from the Scripps atmospheric oxygen flask sampling network, Tellus B, 58, 95-116, 2006.

Marland, G.: Uncertainties in accounting for $\mathrm{CO}_{2}$ from fossil fuels, J. Ind. Ecol., 12, 136-139, 2008. 
Marland, G. and Rotty, R. M.: Carbon-Dioxide Emissions from Fossil-Fuels - a Procedure for Estimation and Results for 19501982, Tellus B, 36, 232-261, 1984.

Marland, G., Hamal, K., and Jonas, M.: How Uncertain Are Estimates of $\mathrm{CO}_{2}$ Emissions?, J. Ind. Ecol., 13, 4-7, 2009.

Masarie, K. A. and Tans, P. P.: Extension and integratino of atmospheric carbon dioxide data into a globally consistent measurement record, J. Geophys. Res.-Atmos., 100, 11593-11610, 1995.

MCI: Foreign Trade Data Dissemination Portal, Ministry of Commerce and Industry, 2017, available at: http://121.241.212.146/, last access: September 2017.

McNeil, B. I., Matear, R. J., Key, R. M., Bullister, J. L., and Sarmiento, J. L.: Anthropogenic $\mathrm{CO}_{2}$ uptake by the ocean based on the global chlorofluorocarbon data set, Science, 299, 235239, 2003.

Melton, J. R. and Arora, V. K.: Competition between plant functional types in the Canadian Terrestrial Ecosystem Model (CTEM) v. 2.0, Geosci. Model Dev., 9, 323-361, https://doi.org/10.5194/gmd-9-323-2016, 2016.

Mercado, L. M., Bellouin, N., Sitch, S., Boucher, O., Huntingford, C., Wild, M., and Cox, P. M.: Impact of changes in diffuse radiation on the global land carbon sink, Nature, 458, 1014-1018, 2009.

Mikaloff Fletcher, S. E., Gruber, N., Jacobson, A. R., Doney, S. C., Dutkiewicz, S., Gerber, M., Follows, M., Joos, F., Lindsay, K., Menemenlis, D., Mouchet, A., Müller, S. A., and Sarmiento, J. L.: Inverse estimates of anthropogenic $\mathrm{CO}_{2}$ uptake, transport, and storage by the oceans, Global Biogeochem. Cy., 20, GB2002, https://doi.org/10.1029/2005GB002530, 2006.

Millar, R. J., Fuglestvedt, J. S., Friedlingstein, P., Rogelj, J., Grubb, M. J., Matthews, H. D., Skeie, R. B., Forster, P. M., Frame, D. J., and Allen, A. R.: Emission budgets and pathways consistent with limiting warming to 1.5 degrees C, Nat. Geosci., 10, 741747, 2017.

Ministry of Mines: Mineral Production, Ministry of Mines, 2017, available at: http://ibm.nic.in/, last access: 25 September 2017.

Myhre, G., Alterskjær, K., and Lowe, D.: A fast method for updating global fossil fuel carbon dioxide emissions, Environ. Res. Lett., 4, 034012, https://doi.org/10.1088/1748-9326/4/3/034012, 2009.

Narayanan, B., Aguiar, A., and McDougall, R.: GTAP 9 Data Base, available at: https://www.gtap.agecon.purdue.edu/databases/v9/ default.asp (last access: 10 September 2017), 2015.

NBS: Value added in Industrial enterprises above the reporting limit grew 7.6\% in August 2017, National Bureau of Statistics of China (NBS), 2017, available at: http://www.stats.gov.cn/tjsj/ zxfb/201707/t20170717_1513524.html, (last access: 15 September 2016), 2017 (in Chinese).

NEA: News conference on the energy situation in the first half of 2017, National Energy Administration of China (NEA), 2017, available at: http://mp.weixin.qq.com/s/DlMA4Zod2y_ nG8pely_iQw, last access: 15 September 2017 (in Chinese).

NOAA/ESRL: NOAA Greenhouse Gas Marine Boundary Layer Reference, available at: https://www.esrl.noaa.gov/gmd/ccgg/ mbl/mbl.html, last access: 30 January 2017.

OEA: Index of Eight Core Industries. Office of the Economic Advisor, Office of the Economic Advisor (OEA), 2017, available at: http://eaindustry.nic.in/home.asp, last access: 4 September 2017.
Oleson, K., Lawrence, D., Bonan, G., Drewniak, B., Huang, M., Koven, C., Levis, S., Li, F., Riley, W., Subin, Z., Swenson, S., Thornton, P., Bozbiyik, A., Fisher, R., Heald, C., Kluzek, E., Lamarque, J., Lawrence, P., Leung, L., Lipscomb, W., Muszala, S., Ricciuto, D., Sacks, W., Tang, J., and Yang, Z.: Technical Description of version 4.5 of the Community Land Model (CLM), NCAR, Boulder, Colorado, USA, 2013.

Paulsen, H., Ilyina, T., Six, K. D., and Stemmler, I.: Incorporating a prognostic representation of marine nitrogen fixers into the global ocean biogeochemical model HAMOCC, J. Adv. Model. Earth Sy., 9, 438-464, 2017.

Peters, G. P., Andrew, R., and Lennos, J.: Constructing a multiregional input-output table using the GTAP database, Econ. Syst. Res., 23, 131-152, 2011a.

Peters, G. P., Minx, J. C., Weber, C. L., and Edenhofer, O.: Growth in emission transfers via international trade from 1990 to 2008 , P. Natl. Acad. Sci. USA, 108, 8903-8908, 2011b.

Peters, G. P., Davis, S. J., and Andrew, R.: A synthesis of carbon in international trade, Biogeosciences, 9, 3247-3276, https://doi.org/10.5194/bg-9-3247-2012, 2012a.

Peters, G. P., Marland, G., Le Quéré, C., Boden, T. A., Canadell, J. G., and Raupach, M. R.: Correspondence: Rapid growth in $\mathrm{CO}_{2}$ emissions after the 2008-2009 global financial crisis, Nature Clim. Change, 2, 2-4, 2012b.

Peters, G. P., Andrew, R. M., Boden, T., Canadell, J. G., Ciais, P., Le Quéré, C., Marland, G., Raupach, M. R., and Wilson, C.: The challenge to keep global warming below $2{ }^{\circ} \mathrm{C}$, Nature Clim. Change, 3, 4-6, 2013.

Peters, G. P., Le Quéré, C., Andrew, R. M., Canadell, J. G., Friedlingstein, P., Ilyina, T., Jackson, R. B., Korsbakken, J. I., McKinley, G., Sitch, S., and Tans, P.: Towards real-time verification of carbon dioxide emissions, Nature Clim. Change, 7, 848-850, https://doi.org/10.1038/s41558-017-0013-9, 2017.

Pfeil, B., Olsen, A., Bakker, D. C. E., Hankin, S., Koyuk, H., Kozyr, A., Malczyk, J., Manke, A., Metzl, N., Sabine, C. L., Akl, J., Alin, S. R., Bates, N., Bellerby, R. G. J., Borges, A., Boutin, J., Brown, P. J., Cai, W.-J., Chavez, F. P., Chen, A., Cosca, C., Fassbender, A. J., Feely, R. A., González-Dávila, M., Goyet, C., Hales, B., Hardman-Mountford, N., Heinze, C., Hood, M., Hoppema, M., Hunt, C. W., Hydes, D., Ishii, M., Johannessen, T., Jones, S. D., Key, R. M., Körtzinger, A., Landschützer, P., Lauvset, S. K., Lefèvre, N., Lenton, A., Lourantou, A., Merlivat, L., Midorikawa, T., Mintrop, L., Miyazaki, C., Murata, A., Nakadate, A., Nakano, Y., Nakaoka, S., Nojiri, Y., Omar, A. M., Padin, X. A., Park, G.-H., Paterson, K., Perez, F. F., Pierrot, D., Poisson, A., Ríos, A. F., Santana-Casiano, J. M., Salisbury, J., Sarma, V. V. S. S., Schlitzer, R., Schneider, B., Schuster, U., Sieger, R., Skjelvan, I., Steinhoff, T., Suzuki, T., Takahashi, T., Tedesco, K., Telszewski, M., Thomas, H., Tilbrook, B., Tjiputra, J., Vandemark, D., Veness, T., Wanninkhof, R., Watson, A. J., Weiss, R., Wong, C. S., and Yoshikawa-Inoue, H.: A uniform, quality controlled Surface Ocean $\mathrm{CO}_{2}$ Atlas (SOCAT), Earth Syst. Sci. Data, 5, 125-143, https://doi.org/10.5194/essd-5-125-2013, 2013.

Pongratz, J., Reick, C. H., Houghton, R. A., and House, J. I.: Terminology as a key uncertainty in net land use and land cover change carbon flux estimates, Earth Syst. Dynam., 5, 177-195, https://doi.org/10.5194/esd-5-177-2014, 2014. 
PPAC: Natural Gas, Petroleum Planning and Analysis Cell, Ministry of Petroleum and Natural Gas, available at: http:// eaindustry.nic.in/home.asp, last access: 25 September 2017a.

PPAC: Petroleum, Petroleum Planning and Analysis Cell, Ministry of Petroleum and Natural Gas, availble at: http://eaindustry.nic. in/home.asp, last access: 15 September 2017b.

Prentice, I. C., Farquhar, G. D., Fasham, M. J. R., Goulden, M. L., Heimann, M., Jaramillo, V. J., Kheshgi, H. S., Le Quéré, C., Scholes, R. J., and Wallace, D. W. R.: The Carbon Cycle and Atmospheric Carbon Dioxide, in: Climate Change 2001: The Scientific Basis. Contribution of Working Group I to the Third Assessment Report of the Intergovernmental Panel on Climate Change, edited by: Houghton, J. T., Ding, Y., Griggs, D. J., Noguer, M., van der Linden, P. J., Dai, X., Maskell, K., and Johnson, C. A., Cambridge University Press, Cambridge, UK and New York, NY, USA, 2001.

Raupach, M. R., Marland, G., Ciais, P., Le Quéré, C., Canadell, J. G., Klepper, G., and Field, C. B.: Global and regional drivers of accelerating $\mathrm{CO}_{2}$ emissions, P. Natl. Acad. Sci. USA, 104, 10288-10293, 2007.

Regnier, P., Friedlingstein, P., Ciais, P., Mackenzie, F. T., Gruber, N., Janssens, I. A., Laruelle, G. G., Lauerwald, R., Luyssaert, S., Andersson, A. J., Arndt, S., Arnosti, C., Borges, A. V., Dale, A. W., Gallego-Sala, A., Goddéris, Y., Goossens, N., Hartmann, J., Heinze, C., Ilyina, T., Joos, F., La Rowe, D. E., Leifeld, J., Meysman, F. J. R., Munhoven, G., Raymond, P. A., Spahni, R., Suntharalingam, P., and Thullner M.: Anthropogenic perturbation of the carbon fluxes from land to ocean, Nat. Geosci., 6, 597-607, 2013.

Reick, C. H., Raddatz, T., Brovkin, V., and Gayler, V.: The representation of natural and anthropogenic land cover change in MPI-ESM, J. Adv. Model. Earth Sy., 5, 459-482, 2013.

Rhein, M., Rintoul, S. R., Aoki, S., Campos, E., Chambers, D., Feely, R. A., Gulev, S., Johnson, G. C., Josey, S. A., Kostianoy, A., Mauritzen, C., Roemmich, D., Talley, L. D., and Wang, F.: Observations: Ocean, chap. 3, in: Climate Change 2013 The Physical Science Basis, Cambridge University Press, Cambridge, UK and New York, NY, USA, 2013.

Rödenbeck, C.: Estimating $\mathrm{CO}_{2}$ sources and sinks from atmospheric mixing ratio measurements using a global inversion of atmospheric transport, Max Plank Institute, MPI-BGC, Jena, Germany, 2005.

Rödenbeck, C., Houweling, S., Gloor, M., and Heimann, M.: $\mathrm{CO}_{2}$ flux history 1982-2001 inferred from atmospheric data using a global inversion of atmospheric transport, Atmos. Chem. Phys., 3, 1919-1964, https://doi.org/10.5194/acp-3-1919-2003, 2003.

Rödenbeck, C., Keeling, R. F., Bakker, D. C. E., Metzl, N., Olsen, A., Sabine, C., and Heimann, M.: Global surface-ocean $p \mathrm{CO}_{2}$ and sea-air $\mathrm{CO}_{2}$ flux variability from an observationdriven ocean mixed-layer scheme, Ocean Sci., 9, 193-216, https://doi.org/10.5194/os-9-193-2013, 2013.

Rödenbeck, C., Bakker, D. C. E., Metzl, N., Olsen, A., Sabine, C., Cassar, N., Reum, F., Keeling, R. F., and Heimann, M.: Interannual sea-air $\mathrm{CO}_{2}$ flux variability from an observationdriven ocean mixed-layer scheme, Biogeosciences, 11, 45994613, https://doi.org/10.5194/bg-11-4599-2014, 2014.

Rödenbeck, C., Bakker, D. C. E., Gruber, N., Iida, Y., Jacobson, A. R., Jones, S., Landschützer, P., Metzl, N., Nakaoka, S., Olsen, A., Park, G.-H., Peylin, P., Rodgers, K. B., Sasse,
T. P., Schuster, U., Shutler, J. D., Valsala, V., Wanninkhof, R., and Zeng, J.: Data-based estimates of the ocean carbon sink variability - first results of the Surface Ocean $p \mathrm{CO}_{2}$ Mapping intercomparison (SOCOM), Biogeosciences, 12, 72517278, https://doi.org/10.5194/bg-12-7251-2015, 2015.

Rogelj, J., Schaeffer, M., Friedlingstein, P., Gillett, N. P., van Vuuren, D. P., Riahi, K., Allen, M., and Knutti, R.: Differences between carbon budget estimates unravelled, Nature Clim. Change, 6, 245-252, 2016.

Rypdal, K., Paciomik, N., Eggleston, S., Goodwin, J., Irving, W., Penman, J., and Woodfield, M.: Introduction to the 2006 Guidelines, chap. 1, in: 2006 IPCC Guidelines for National Greenhouse Gas Inventories, edited by: Eggleston, S., Buendia, L., Miwa, K., Ngara, T., and Tanabe, K., Institute for Global Environmental Strategies (IGES), Hayama, Kanagawa, Japan, 2006.

Saunois, M., Bousquet, P., Poulter, B., Peregon, A., Ciais, P., Canadell, J. G., Dlugokencky, E. J., Etiope, G., Bastviken, D., Houweling, S., Janssens-Maenhout, G., Tubiello, F. N., Castaldi, S., Jackson, R. B., Alexe, M., Arora, V. K., Beerling, D. J., Bergamaschi, P., Blake, D. R., Brailsford, G., Brovkin, V., Bruhwiler, L., Crevoisier, C., Crill, P., Covey, K., Curry, C., Frankenberg, C., Gedney, N., Höglund-Isaksson, L., Ishizawa, M., Ito, A., Joos, F., Kim, H.-S., Kleinen, T., Krummel, P., Lamarque, J.-F., Langenfelds, R., Locatelli, R., Machida, T., Maksyutov, S., McDonald, K. C., Marshall, J., Melton, J. R., Morino, I., Naik, V., O'Doherty, S., Parmentier, F.-J. W., Patra, P. K., Peng, C., Peng, S., Peters, G. P., Pison, I., Prigent, C., Prinn, R., Ramonet, M., Riley, W. J., Saito, M., Santini, M., Schroeder, R., Simpson, I. J., Spahni, R., Steele, P., Takizawa, A., Thornton, B. F., Tian, H., Tohjima, Y., Viovy, N., Voulgarakis, A., van Weele, M., van der Werf, G. R., Weiss, R., Wiedinmyer, C., Wilton, D. J., Wiltshire, A., Worthy, D., Wunch, D., Xu, X., Yoshida, Y., Zhang, B., Zhang, Z., and Zhu, Q.: The global methane budget 2000-2012, Earth Syst. Sci. Data, 8, 697-751, https://doi.org/10.5194/essd-8-697-2016, 2016.

SCCL: Provisional Production and Dispatches Performance, Singareni Collieries Company Limited (SCCL), 2017, available at: https://scclmines.com/scclnew/performance_production.asp, last access: 2 October 2017.

Schimel, D., Alves, D., Enting, I., Heimann, M., Joos, F., Raynaud, D., Wigley, T., Prater, M., Derwent, R., Ehhalt, D., Fraser, P., Sanhueza, E., Zhou, X., Jonas, P., Charlson, R., Rodhe, H., Sadasivan, S., Shine, K. P., Fouquart, Y., Ramaswamy, V., Solomon, S., Srinivasan, J., Albritton, D., Derwent, R., Isaksen, I., Lal, M., and Wuebbles, D.: Radiative Forcing of Climate Change, in: Climate Change 1995 The Science of Climate Change. Contribution of Working Group I to the Second Assessment Report of the Intergovernmental Panel on Climate Change, edited by: Houghton, J. T., Meira Rilho, L. G., Callander, B. A., Harris, N., Kattenberg, A., and Maskell, K., Cambridge University Press, Cambridge, UK and New York, NY, USA, 1995.

Schimel, D., Stephens, B. B., and Fisher, J. B.: Effect of increasing $\mathrm{CO}_{2}$ on the terrestrial carbon sink, P. Natl. Acad. Sci. USA, 112, 436-441, 2015.

Schwietzke, S., Sherwood, O. A., Bruhwiler, L. M. P., Miller, J. B., Etiope, G., Dlugokencky, E. J., Michel, S. E., Arling, V. A., Vaughn, B. H., White, J. W. C., and Tans, P. P.: Upward revision of global fossil fuel methane emissions based on isotope database, Nature, 538, 88-91, 2016. 
Schwinger, J., Goris, N., Tjiputra, J. F., Kriest, I., Bentsen, M., Bethke, I., Ilicak, M., Assmann, K. M., and Heinze, C.: Evaluation of NorESM-OC (versions 1 and 1.2), the ocean carboncycle stand-alone configuration of the Norwegian Earth System Model (NorESM1), Geosci. Model Dev., 9, 2589-2622, https://doi.org/10.5194/gmd-9-2589-2016, 2016.

Séférian, R., Bopp, L., Gehlen, M., Orr, J., Ethé, C., Cadule, P., Aumont, O., Salas y Mélia, D., Voldoire, A., and Madec, G.: Skill assessment of three earth system models with common marine biogeochemistry, Clim. Dynam., 40, 2549-2573, 2013.

Sitch, S., Smith, B., Prentice, I. C., Arneth, A., Bondeau, A., Cramer, W., Kaplan, J. O., Levis, S., Lucht, W., Sykes, M. T., Thonicke, K., and Venevsky, S.: Evaluation of ecosystem dynamics, plant geography and terrestrial carbon cycling in the LPJ dynamic global vegetation model, Glob. Change Biol., 9, 161-185, 2003.

Smith, B., Wårlind, D., Arneth, A., Hickler, T., Leadley, P., Siltberg, J., and Zaehle, S.: Implications of incorporating $\mathrm{N}$ cycling and $\mathrm{N}$ limitations on primary production in an individualbased dynamic vegetation model, Biogeosciences, 11, 20272054, https://doi.org/10.5194/bg-11-2027-2014, 2014.

Stephens, B. B., Gurney, K. R., Tans, P. P., Sweeney, C., Peters, W., Bruhwiler, L., Ciais, P., Ramonet, M., Bousquet, P., Nakazawa, T., Aoki, S., Machida, T., Inoue, G., Vinnichenko, N., Lloyd, J., Jordan, A., Heimann, M., Shibistova, O., Langenfelds, R. L., Steele, L. P., Francey, R. J., and Denning, A. S.: Weak northern and strong tropical land carbon uptake from vertical profiles of atmospheric $\mathrm{CO}_{2}$, Science, 316, 1732-1735, 2007.

Stocker, T., Qin, D., and Platner, G.-K.: Climate Change 2013 The Physical Science Basis, Cambridge University Press, Cambridge, UK and New York, NY, USA, 2013.

Swart, N. C., Fyfe, J. C., Saenko, O. A., and Eby, M.: Wind-driven changes in the ocean carbon sink, Biogeosciences, 11, 61076117, https://doi.org/10.5194/bg-11-6107-2014, 2014.

Tian, H. Q., Chen, G. S., Lu, C. Q., Xu, X. F., Hayes, D. J., Ren, W., Pan, S. F., Huntzinger, D. N., and Wofsy, S. C.: North American terrestrial $\mathrm{CO}_{2}$ uptake largely offset by $\mathrm{CH}_{4}$ and $\mathrm{N}_{2} \mathrm{O}$ emissions: toward a full accounting of the greenhouse gas budget, Climatic Change, 129, 413-426, 2015.

UN: National Accounts Main Aggregates Database, United Nations Statistics Division, available at: http://unstats.un.org/unsd/ snaama/Introduction.asp (last access: 2 February 2017), 2016.

UN: Energy Statistics, United Nations Statistics Division, available at: http://unstats.un.org/unsd/energy/, last access: June 2017.

UNFCCC: National Inventory Submissions, available at: http://unfccc.int/national_reports/annex_i_ghg_inventories/ national_inventories_submissions/items/10116.php, last access: 7 June 2017.

USGS: 2014 Minerals Yearbook - Cement, US Geological Survey, Reston, Virginia, USA, 2017

van der Laan-Luijkx, I. T., van der Velde, I. R., van der Veen, E., Tsuruta, A., Stanislawska, K., Babenhauserheide, A., Zhang, H. F., Liu, Y., He, W., Chen, H., Masarie, K. A., Krol, M. C., and Peters, W.: The CarbonTracker Data Assimilation Shell (CTDAS) v1.0: implementation and global carbon balance 2001-2015, Geosci. Model Dev., 10, 2785-2800, https://doi.org/10.5194/gmd-10-2785-2017, 2017.

van der Velde, I. R., Miller, J. B., Schaefer, K., van der Werf, G. R., Krol, M. C., and Peters, W.: Terrestrial cycling of ${ }^{13} \mathrm{CO}_{2}$ by photosynthesis, respiration, and biomass burning in SiBCASA, Biogeosciences, 11, 6553-6571, https://doi.org/10.5194/bg-116553-2014, 2014.

van der Werf, G. R., Randerson, J. T., Giglio, L., Collatz, G. J., Mu, M., Kasibhatla, P. S., Morton, D. C., DeFries, R. S., Jin, Y., and van Leeuwen, T. T.: Global fire emissions and the contribution of deforestation, savanna, forest, agricultural, and peat fires (1997-2009), Atmos. Chem. Phys., 10, 11707-11735, https://doi.org/10.5194/acp-10-11707-2010, 2010.

van der Werf, G. R., Randerson, J. T., Giglio, L., van Leeuwen, T. T., Chen, Y., Rogers, B. M., Mu, M., van Marle, M. J. E., Morton, D. C., Collatz, G. J., Yokelson, R. J., and Kasibhatla, P. S.: Global fire emissions estimates during 1997-2016, Earth Syst. Sci. Data, 9, 697-720, https://doi.org/10.5194/essd-9-697-2017, 2017.

Viovy, N.: CRUNCEP data set, available at: ftp://nacp.ornl.gov/ synthesis/2009/frescati/temp/land_use_change/original/readme. htm, last access: June 2016.

Walker, A. P., Quaife, T., van Bodegom, P. M., De Kauwe, M. G., Keenan, T. F., Joiner, J., Lomas, M. R., MacBean, N., Xu, C. G., Yang, X. J., and Woodward, F. I.: The impact of alternative traitscaling hypotheses for the maximum photosynthetic carboxylation rate (V-cmax) on global gross primary production, New Phytol., 215, 1370-1386, 2017.

Wanninkhof, R., Park, G.-H., Takahashi, T., Sweeney, C., Feely, R., Nojiri, Y., Gruber, N., Doney, S. C., McKinley, G. A., Lenton, A., Le Quéré, C., Heinze, C., Schwinger, J., Graven, H., and Khatiwala, S.: Global ocean carbon uptake: magnitude, variability and trends, Biogeosciences, 10, 1983-2000, https://doi.org/10.5194/bg-10-1983-2013, 2013.

Watson, R. T., Rodhe, H., Oeschger, H., and Siegenthaler, U.: Greenhouse Gases and Aerosols, in: Climate Change: The IPCC Scientific Assessment. Intergovernmental Panel on Climate Change (IPCC), edited by: Houghton, J. T., Jenkins, G. J., and Ephraums, J. J., Cambridge University Press, Cambridge, UK, 1990.

Wenzel, S., Cox, P. M., Eyring, V., and Friedlingstein, P.: Projected land photosynthesis constrained by changes in the seasonal cycle of atmospheric $\mathrm{CO}_{2}$, Nature, 538, 499-501, 2016.

Wilkenskjeld, S., Kloster, S., Pongratz, J., Raddatz, T., and Reick, C. H.: Comparing the influence of net and gross anthropogenic land-use and land-cover changes on the carbon cycle in the MPI-ESM, Biogeosciences, 11, 4817-4828, https://doi.org/10.5194/bg-11-4817-2014, 2014.

Woodward, F. I. and Lomas, M. R.: Vegetation dynamics - simulating responses to climatic change, Biol. Rev., 79, 643-670, 2004.

Woodward, F. I., Smith, T. M., and Emanuel, W. R.: A global land primary productivity and phytogeography model, Global Biogeochem. Cy., 9, 471-490, 1995.

Xi, F., Davis, S. J., Ciais, P., Crawford-Brown, D., Guan, D., Pade, C., Shi, T., Syddall, M., Lv, J., Ji, L., Bing, L., Wang, J., Wei, W., Yang, K.-H., Lagerblad, B., Galan, I., Andrade, C., Zhang, Y., and Liu, Z.: Substantial global carbon uptake by cement carbonation, Nat. Geosci., 9, 880-883, 2016.

Zaehle, S. and Friend, A. D.: Carbon and nitrogen cycle dynamics in the O-CN land surface model: 1. Model description, site-scale evaluation, and sensitivity to parameter estimates, Global Biogeochem. Cy., 24, GB1005, https://doi.org/10.1029/2009GB003521, 2010. 
Zaehle, S., Ciais, P., Friend, A. D., and Prieur, V.: Carbon benefits of anthropogenic reactive nitrogen offset by nitrous oxide emissions, Nat. Geosci., 4, 601-605, 2011.

Zscheischler, J., Mahecha, M. D., Avitabile, V., Calle, L., Carvalhais, N., Ciais, P., Gans, F., Gruber, N., Hartmann, J., Herold, M., Ichii, K., Jung, M., Landschützer, P., Laruelle, G. G., Lauerwald, R., Papale, D., Peylin, P., Poulter, B., Ray, D., Regnier, P., Rödenbeck, C., Roman-Cuesta, R. M., Schwalm, C., Tramontana, G., Tyukavina, A., Valentini, R., van der Werf, G., West, T. O., Wolf, J. E., and Reichstein, M.: Reviews and syntheses: An empirical spatiotemporal description of the global surface-atmosphere carbon fluxes: opportunities and data limitations, Biogeosciences, 14, 3685-3703, https://doi.org/10.5194/bg-14-3685-2017, 2017. 